\title{
Pyroacm Resin: An Acetamidomethyl Derived Resin for Solid Phase Synthesis of Peptides through Side Chain Anchoring of C- Terminal Cysteine Residues
}

Vinayak Juvekar and Young Dae Gong*

* Innovative Drug Library Research Center, Dongguk University, Seoul 100-715, South Korea *ydgong@dongguk.edu

Table of contents:

I. Abbreviations and acronyms.............................S2

II. General information and methods.........................S2

III. Experimental details.......................................S3

IV. IR data......................................................

V. Crude HPLC and LCMS data................................S16

VI. NMR data..................................................S29

VII. LC MS/MS data of pure samples..............................S34 


\section{Abbreviations and acronyms}

SPPS - solid phase peptide synthesis; HBTU - $N, N, N^{\prime}, N^{\prime}$-tetramethyl- $O$-(1H-benzotriazol-1-yl)uronium hexafluorophosphate; HOBt - 1-hydroxybenzotriazole; PG - protecting group; Pbf - 2,2,4,6,7pentamethyldihydrobenzofurane-5-sulfonyl; DIPEA - N, $N$ '-diisopropylethylamine; $\mathrm{ScmCl}$ - methoxycarbonylsulfenyl chloride; $\mathrm{NaH}$ - sodium hydride; $\mathrm{Et}_{2} \mathrm{O}$ - diethyl ether; $\mathrm{ACN}$ - acetonitrile; $\mathrm{AcOH}$ - acetic acid; $\mathrm{MeI}$ - methyl iodide; $\mathrm{Ac}_{2} \mathrm{O}$ - acetic anhydride; $\mathrm{BuLi}$ - n-butyllithium; $\mathrm{LiCl}$ - lithium chloride; LiHMDS - lithium bis(trimethylsilyl)amide; $\mathrm{EtOH}$ - ethanol; $\mathrm{MeOH}$ - methanol; $\mathrm{x}$ - times; rpm - rotations per minute; MPLC - medium pressure liquid chromatography; ESI-MS - electrospray ionization mass spectrometry; RP-HPLC - reversed-phase high performance liquid chromatography;

\section{General information}

Fmoc- and Boc-amino acid derivatives, HBTU, HOBt obtained from GLS (Shanghai, China). Merrifield Resin was obtained from Beadtech (Seoul, Korea). $\mathrm{Pd}\left(\mathrm{PPh}_{3}\right)_{4}$ has been purchased from Strem Chemicals (MA, USA). TMEDA, HMPA, LiHMDS, BuLi, LDA, LiCl, $\mathrm{PhSiH}_{3}$, DIPEA, Piperidine and TFA were obtained from Aldrich (Milwaukee, USA). ScmCl, TIPS, NaH, Et $2 \mathrm{O}, \mathrm{ACN}$, DMSO were obtained from Acros Chemicals (New Jersey, USA). $\mathrm{DMF} \mathrm{CH}_{2} \mathrm{Cl}_{2}$, toluene, THF (HPLC grade) were purified by solvent purifier prior to use. All the reactions were conducted in flamedried or oven-dried glassware under an atmosphere of argon. SPPS carried out manually in a cylinder glass vessel with a Teflon screw cap containing a polyethylene frit. Solvents and soluble reagents were removed by suction. Infrared (IR) spectra were recorded on a Smiths IdentityIR ATR-FTIR spectrometer. A Scinco S4100 PDA UV-Vis spectrophotometer was used to measure UV spectra in quartz cuvette of $0.5 \mathrm{~cm}$ path length. An Agilent 1260 infinity instrument, equipped with an Eclipse plus-C18 reversed-phase analytical column (4.6 mm x $250 \mathrm{~mm}, 5 \mu \mathrm{M})$, was used for HPLC analysis. HPLC separation used a flow rate of $1 \mathrm{~mL} / \mathrm{min}$ and $1 \% / \mathrm{min}$ of $\mathrm{ACN}(0.1 \% \mathrm{TFA})$ into the (Water:ACN::95:5, containing $0.1 \%$ TFA) after column equilibration from $5 \mathrm{~min}$ to $45 \mathrm{~min}$ and from $45 \mathrm{~min}$ to $60 \mathrm{~min}$ the gradient raised from $45 \%$ to $90 \%$ of ACN (0.1\% TFA). An Agilent 6460 triple Quad LCMS, coupled to an Agilent 1290 infinity LC instrument equipped with an Eclipse plus C18 analytical reversed-phase column $(4.6 \mathrm{~mm} \times 100 \mathrm{~mm}, 3.5 \mu \mathrm{m})$, was used for analysis. Linear gradients of $\mathrm{ACN}$ into water $\left(5 \mathrm{mM} \mathrm{NH} \mathrm{HCO}_{2}\right)$ were used at a flow rate of $0.5 \mathrm{~mL} \cdot \mathrm{min}^{-1}$ and a run time of 12 min in the ESI mode. An Agilent 6550 iFunnel Q-TOF coupled to Agilent 1290 infinity II LC spectrometer, equipped with an zorbax extend C18 analytical reversed-phase column $(2.1 \mathrm{~mm} \times 50 \mathrm{~mm}, 1.8 \mu \mathrm{m})$, was used for HRMS measurements. Linear gradients of ACN into water $\left(5 \mathrm{mM} \mathrm{NH}_{4} \mathrm{HCO}_{2}\right)$ were used at a flow rate of $0.5 \mathrm{~mL} \cdot \mathrm{min}^{-1}$ and a run time of $7 \mathrm{~min}$ in the ESI mode. All LC eluents were monitored at $220 \mathrm{~nm}$. ILSHIN BIOBASE CO., LTD freeze dryer used for lyophilization. ${ }^{1} \mathrm{H}$ NMR spectra were measured on a Bruker Ascend ${ }^{\mathrm{TM}} 500$ instrument at $500 \mathrm{MHz}$. Residual chloroform (7.26 ppm) was used as an internal standard. ${ }^{13} \mathrm{C}$ NMR spectra were measured at $126 \mathrm{MHz}$ with residual chloroform (77.16 ppm) as an internal standard. A Waters PrepHPLC containing Waters 2525 Binary Gradient System with a Waters 2487 dual wavelength UV-Vis detector and reverse phase column (19 $\mathrm{mm}$ x $250 \mathrm{~mm}, 5 \mu \mathrm{M})$ was used to purify crude peptides. Analytical TLC was performed using plates coated with a $0.25 \mathrm{~mm}$ thickness of silica gel, and compounds were visualized using UV light, iodine or $\mathrm{KMnO}_{4}$ staining. Normal phase flash chromatography was performed on an automated MPLC of Biotage IsoleraOne instrument (silica gel 230-400 mesh size).

Solid-phase peptide synthesis via Fmoc protocol: Resin was swollen in DMF for $10 \mathrm{~min}$. Amino acids were preactivated for 2 min by HBTU/HOBt/DIPEA (4/4/8) treatment with $0.4 \mathrm{M}$ Fmoc protected amino acids (4.0 equiv) in DMF. In each case, the mixture was added to the resin and the vessel tumbled on shaker for $1 \mathrm{~h}$ at $25{ }^{\circ} \mathrm{C}$ and $160 \mathrm{rpm}$. The resin was washed with DMF (5 x $1 \mathrm{~min}$ ), $\mathrm{CH}_{2} \mathrm{Cl}_{2}$ (5 x $1 \mathrm{~min}$ ) and DMF (5 x $1 \mathrm{~min}$ ). A small portion of the resin was checked for Kaiser Test. In the case of a positive test, the process was repeated. Deprotection of the Fmoc group was achieved by treatment of the resin with $20 \%$ piperidine in DMF $(2 \times 10 \mathrm{~min})$. Washings between deprotection and coupling were performed with DMF $(5 \times 1 \mathrm{~min}), \mathrm{CH}_{2} \mathrm{Cl}_{2}(5 \times 1 \mathrm{~min})$ and $\mathrm{DMF}(5 \times 1 \mathrm{~min})$. Following the final coupling or deprotection step the resin was washed with $\mathrm{DMF}(5 \times 1 \mathrm{~min}), \mathrm{CH}_{2} \mathrm{Cl}_{2}(5 \times 1 \mathrm{~min})$ and dried under high vacuum.

Solid-phase peptide syntheses via Boc protocol: Resin was swollen in DMF for $10 \mathrm{~min}$. Preactivation of the amino acid involves HBTU/HOBt/DIPEA (4/4/8) treatment with $0.4 \mathrm{M}$ Boc protected amino acids (4.0 equiv) in DMF for 2 min. In each case, the mixture was added to the resin and the vessel was tumbled on shaker at $25{ }^{\circ} \mathrm{C}$ and $160 \mathrm{rpm}$ for 1 h. The resin was washed with DMF (5 x $1 \mathrm{~min}), \mathrm{CH}_{2} \mathrm{Cl}_{2}(5 \times 1 \mathrm{~min}), \mathrm{DMF}(5 \times 1 \mathrm{~min})$ and $\mathrm{CH}_{2} \mathrm{Cl}_{2}(5 \times 1 \mathrm{~min})$. A small portion of the resin was checked for Kaiser Test and if the test was positive the process was repeated. Deprotection of the Boc group was achieved by treatment of the resin with 100\% TFA for $(2 \times 2 \mathrm{~min})$. Washings between deprotection and coupling were performed with $\mathrm{CH}_{2} \mathrm{Cl}_{2}(5 \times 1 \mathrm{~min})$ and DMF $(5 \times 1 \mathrm{~min})$. The in situ neutralization used in Bocchemistry for solid phase peptide synthesis protocol was followed. ${ }^{1}$ After completion of the final coupling or deprotection step the resin was washed with $\mathrm{CH}_{2} \mathrm{Cl}_{2}(5 \times 1 \mathrm{~min}), \mathrm{DMF}(5 \times 1 \mathrm{~min}), \mathrm{CH}_{2} \mathrm{Cl}_{2}(5 \times 1 \mathrm{~min})$ and dried under high vacuum. 
Fmoc quantitative analysis: Precisely $10 \mathrm{mg}$ of dry resin was transferred to a $5 \mathrm{~mL}$ glass vial and added $1 \mathrm{~mL}$ of 20 vol \% piperidine in DMF. The resin vortexed for few second and shaken for $1 \mathrm{~h}$ at $160 \mathrm{rpm}$ and $25^{\circ} \mathrm{C}$ followed with 2 min vortex. $100 \mu \mathrm{L}$ of the solution was added to $5 \mathrm{~mL}$ of DMF. The absorbance measured at $301 \mathrm{~nm}$. $\left(\varepsilon\right.$ is $7800 \mathrm{~L} \mathrm{~mol}^{-}$ $\left.{ }^{1} \mathrm{~cm}^{-1}\right)$

Ninhydrin quantitative analysis: Approximately $2-3 \mathrm{mg}$ dry resin was placed in a $5 \mathrm{~mL}$ glass vial and $200 \mu \mathrm{L}$ of ninhydrin test reagent a and $50 \mu \mathrm{L}$ of ninhydrin test reagent $\mathrm{b}$ were added. The vial was heated on a sand bath at $100{ }^{\circ} \mathrm{C}$ for $10 \mathrm{~min}$ and immediately cooled to $0{ }^{\circ} \mathrm{C}$, and $4 \mathrm{~mL}$ of $60 \%$ aq ethanol was added and the resin was separated by filtration and washed with $2 \mathrm{~mL}$ of $0.5 \mathrm{M} \mathrm{Bu} \mathrm{N}^{+} \mathrm{Cl}$ in $\mathrm{CH}_{2} \mathrm{Cl}_{2}$. The filtrate was diluted to $50 \mathrm{~mL}$ with $60 \%$ aq ethanol and the absorbance was measured at $570 \mathrm{~nm}$. ( $\varepsilon$ considered $1.5 \times 10^{-4}$ in all the cases)

Removal of Allyl group: The resin swollen in $50 \mathrm{x}$ dry $\mathrm{CH}_{2} \mathrm{Cl}_{2}$ for 15 min under argon atmosphere, was slowly added via syringe $\mathrm{Pd}\left(\mathrm{PPh}_{3}\right)_{4}\left(0.75\right.$ equiv), $\mathrm{Ph}_{3} \mathrm{SiH}$ (30 equiv) in $20 \mathrm{x} \mathrm{CH}_{2} \mathrm{Cl}_{2}$. The resin was tumbled in shaker for $1.5 \mathrm{~h}$ at $25{ }^{\circ} \mathrm{C}, 160 \mathrm{rpm}$ and the resin was washed with $\mathrm{CH}_{2} \mathrm{Cl}_{2}(5 \times 1 \mathrm{~min}), \mathrm{DMF}(5 \times 1 \mathrm{~min}), \mathrm{CH}_{2} \mathrm{Cl}_{2}(5 \times 1 \mathrm{~min})$ and dried under high vacuum. The process was repeated twice.

\section{Labile Thiol-sulfenyl deprotection:}

An argon purged solution of $5 \mathrm{vol} \%$ DTT in $\mathrm{H}_{2} \mathrm{O}$ (ca., 50 equiv of DTT per disulfide bond) was added to crude peptide under argon. ACN was added dropwise with stirring until a homogenous mixture is obtained. The mixture was stirred for $10 \mathrm{~min}$ and purified by using HPLC.

\section{Oxidation of free thiol:}

The reduced peptide in $1000 \mathrm{x}$ of DMSO: $\mathrm{H}_{2} \mathrm{O}$ (1:9) was immobilized for 24-48 h at rt. ACN was added dropwise until a homogenous mixture is obtained. The reaction progress was monitored by using LCMS and once completed it was subjected to HPLC separation

\section{Experimental details}

\section{Scheme1: Synthesis of Pyroacm linker.}

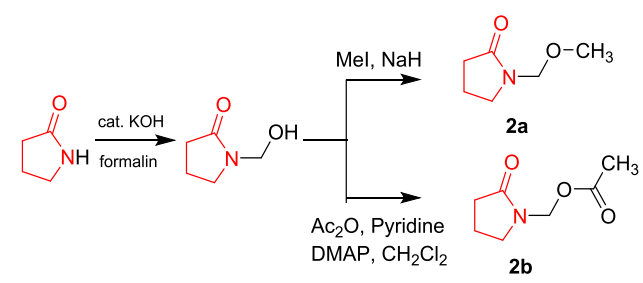

1-(methoxymethyl)pyrrolidin-2-one (2a). Pyrrolidon-2-one (25 g, $0.294 \mathrm{~mol})$ was dissolved in $1 \mathrm{M} \mathrm{KOH} \mathrm{(0.01} \mathrm{equiv),}$ followed by slow addition of $36 \%$ aq formalin $(24.5 \mathrm{~mL}, 0.294 \mathrm{~mol})$ at $\mathrm{rt}$. The mixture was stirred at $\mathrm{rt}$ for $2 \mathrm{~h}$, and concentrated under reduced pressure. The crude solid containing 1-(hydroxymethyl)pyrrolidin-2-one (11.5 g, $0.1 \mathrm{~mole})$ was dissolved in THF $(575 \mathrm{~mL})$, and then $\mathrm{NaH}(4.4 \mathrm{~g}, 0.11 \mathrm{~mol})$ was added in portions at $0{ }^{\circ} \mathrm{C}$. When the $\mathrm{H}_{2}$ evolution ceased, MeI $(6.85 \mathrm{~mL}, 0.11 \mathrm{~mol})$ was added dropwise. The mixture was stirred at $0{ }^{\circ} \mathrm{C}$ for overnight. After the consumption of starting material, $\mathrm{MeOH}(5 \mathrm{~mL})$ was added dropwise to quench unreacted $\mathrm{NaH}$. The mixture was concentrated under reduced pressure giving a residue that was mixed with $\mathrm{CH}_{2} \mathrm{Cl}_{2}(200 \mathrm{~mL})$. The organic layer filtered, dried over $\mathrm{MgSO}_{4}$ and concentrated under reduced pressure. The residue was subjected to flash silica chromatography eluting with a gradient of $\mathrm{CH}_{2} \mathrm{Cl}_{2}$ :methanol $(100: 0 \rightarrow 90: 10)$ to yield the product as a pale yellow liquid $(10.96 \mathrm{~g}, 84 \%)$. $\mathbf{R}_{\mathbf{f}}=0.25\left(\mathrm{CH}_{2} \mathrm{Cl}_{2}\right.$ : methanol, 9.5:0.5) ${ }^{1} \mathbf{H} \mathbf{N M R}\left(500 \mathrm{MHz}, \mathrm{CDCl}_{3}\right) \delta \mathrm{H} 4.69(\mathrm{~s}, 2 \mathrm{H}), 3.49(\mathrm{t}, J=7.1 \mathrm{~Hz}, 2 \mathrm{H}), 3.29(\mathrm{~s}$, $2 \mathrm{H}), 2.45(\mathrm{t}, J=8.1 \mathrm{~Hz}, 2 \mathrm{H}), 2.13-2.03(\mathrm{~m}, 2 \mathrm{H}) .{ }^{13} \mathbf{C}$ NMR $(126 \mathrm{MHz}, \mathrm{CDCl} 3) \delta \mathrm{C} 176.3,74.0,56.1,46.0,31.2,18.1$.

(2-oxopyrrolidin-1-yl)methyl acetate (2b). The crude 1-(hydroxymethyl)pyrrolidin-2-one (11.5 g, $0.1 \mathrm{~mole})$ from above was dissolved in $\mathrm{CH}_{2} \mathrm{Cl}_{2}$ (300 mL). Pyridine (16.1 mL, $\left.0.2 \mathrm{~mol}\right)$, DMAP (24.15 g, $\left.0.2 \mathrm{~mol}\right)$ and Ac $\mathrm{O}$ (19 mL, $0.2 \mathrm{~mol}$ ) were added to the solution dropwise. After completion of the reaction (via TLC), the mixture was concentrated in vacuo and the residue obtained was subjected to flash chromatography eluting with a gradient of $\mathrm{CH}_{2} \mathrm{Cl}_{2}$ :methanol $(100: 0 \rightarrow 90: 10)$ to yield the product as a colorless liquid $(12.5 \mathrm{~g}, 79 \%) . \mathbf{R} \mathbf{f}=0.3\left(\mathrm{CH}_{2} \mathrm{Cl}_{2}\right.$ : methanol, 9.5:0.5) ${ }^{\mathbf{1}} \mathbf{H} \mathbf{~ N M R}$ $\left(500 \mathrm{MHz}, \mathrm{CDCl}_{3}\right) \delta \mathrm{H} 5.33(\mathrm{~s}, 2 \mathrm{H}), 3.55(\mathrm{t}, J=7.1 \mathrm{~Hz}, 2 \mathrm{H}), 2.42(\mathrm{t}, J=8.2 \mathrm{~Hz}, 2 \mathrm{H}), 2.08(\mathrm{~s}, 3 \mathrm{H}) 2.13-2.03(\mathrm{~m}, 2 \mathrm{H})$. ${ }^{13}$ C NMR $\left(126 \mathrm{MHz}, \mathrm{CDCl}_{3}\right) \delta \mathrm{C} 176.2,170.9,66.7,47.0,30.7,20.8,18.0$.

Allyl ester formation: In $250 \mathrm{~mL}$ round bottomed flask containing PG-Cys(Trt)-OH (0.01 mole, 1 equiv) was added 
$75 \mathrm{~mL}$ of DMF. To the homogenous reaction mixture DIPEA ( 0.02 mole, 2 equiv) was added dropwise at $0{ }^{\circ} \mathrm{C}$. After 10 min Allylbromide $\left(0.02\right.$ mole, 2 equiv) was added dropwise at $0{ }^{\circ} \mathrm{C}$. The reaction mass brought to $25^{\circ} \mathrm{C}$ and stirred overnight. Once TLC showed completion of reaction, $200 \mathrm{~mL}$ of ethyl acetate was added into it and washed organic layer with water $(4 \times 200 \mathrm{~mL})$, brine $(1 \times 100 \mathrm{~mL})$, dried over $\mathrm{MgSO}_{4}$ and concentrated under reduced pressure. The residue was purified by flash chromatography eluting with gradient of Hexane:Ethyl acetate (100:0 -> 60:40).

Fmoc-L-Cys(Trt)-OAllyl (4a $\left.\mathbf{1}^{\mathbf{1}}\right)$. $\mathbf{R}_{\mathbf{f}}=0.4$ (Hexane: ethyl acetate, 7:3) gummy solid (5.2 g, 83\%) ESI-MS: for Trt $\quad \mathrm{C}_{40} \mathrm{H}_{35} \mathrm{NO}_{4} \mathrm{~S}\left[\mathrm{M}+\mathrm{Na}^{+}\right]^{+}$; cald 648.2, found $648.2{ }^{1} \mathbf{H} \mathbf{N M R}\left(500 \mathrm{MHz}, \mathrm{CDCl}_{3}\right) \delta \mathrm{H} 7.76-7.71(\mathrm{~m}$, $\left.\mathrm{s}^{2} \quad 2 \mathrm{H}\right), 7.62-7.56(\mathrm{~m}, 2 \mathrm{H}), 7.42-7.34(\mathrm{~m}, 8 \mathrm{H}), 7.29-7.22(\mathrm{~m}, 8 \mathrm{H}), 7.19-7.15(\mathrm{~m}, 3 \mathrm{H}), 5.89-5.77$ Fmoc$\underset{4 a^{1}}{1}-2.54(\mathrm{~m}, 2 \mathrm{H}){ }^{13} \mathbf{C}$ NMR $\left(126 \mathrm{MHz}, \mathrm{CDCl}_{3}\right) \delta \mathrm{C} 170.3,155.7,144.3,144.0,143.8,141.4,131.5$ $129.6,128.1,127.8,127.2,127.0,125.1,125.2,120.1,118.9,67.2,67.1,66.3,53.1,47.2,34.1$.

Fmoc-D-Cys(Trt)-OAllyl (4a $\left.\mathbf{a}^{\mathbf{2}}\right)$. $\mathbf{R}_{\mathbf{f}}=0.4$ (Hexane: ethyl acetate, 7:3) gummy solid (5.1 g, 81\%) ESI-MS: for<smiles>C=COC(=O)C(CCSCC)NC(F)F</smiles>
$\mathrm{C}_{40} \mathrm{H}_{35} \mathrm{NO}_{4} \mathrm{~S}\left[\mathrm{M}+\mathrm{Na}^{+}\right]^{+}$; cald 648.2, found $648.2{ }^{1} \mathbf{H} \mathbf{N M R}\left(500 \mathrm{MHz}, \mathrm{CDCl}_{3}\right) \delta \mathrm{H} 7.78-7.69(\mathrm{~m}$, 2H), $7.62-7.55(\mathrm{~m}, 2 \mathrm{H}), 7.48-7.32(\mathrm{~m}, 8 \mathrm{H}), 7.32-7.20(\mathrm{~m}, 8 \mathrm{H}), 7.19-7.14(\mathrm{~m}, 3 \mathrm{H}), 5.89-$ $5.76(\mathrm{~m}, 1 \mathrm{H}), 5.41-5.16(\mathrm{~m}, 3 \mathrm{H}), 4.59(\mathrm{~s}, 2 \mathrm{H}), 4.69-4.51(\mathrm{~m}, 2 \mathrm{H}), 4.45-4.31(\mathrm{~m}, 3 \mathrm{H}), 2.73-$ $2.61(\mathrm{~m}, 2 \mathrm{H}) .{ }^{13} \mathrm{C}$ NMR $\left(126 \mathrm{MHz}, \mathrm{CDCl}_{3}\right) \delta \mathrm{C} 170.3,155.7,144.3,143.9,143.8,141.3,131.5$, $129.6,128.1,127.8,127.1,126.7,125.2,125.2,120.0,118.8,67.2,67.1,66.3,53.1,47.1,34.1$.

Boc-L-Cys(Trt)-OAllyl (4b). $\mathbf{R}_{\mathbf{f}}=0.35$ (Hexane: ethyl acetate, 7:3) Sticky colourless liquid (3.9 g, 78\%) ESI-MS: for

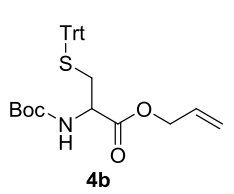

$\mathrm{C}_{30} \mathrm{H}_{33} \mathrm{NO}_{4} \mathrm{~S}\left[\mathrm{M}+\mathrm{Na}^{+}\right]^{+}$; cald 526.2, found 526.1 ${ }^{1} \mathbf{H} \mathbf{~ N M R}\left(500 \mathrm{MHz}, \mathrm{CDCl}_{3}\right) \delta \mathrm{H} 7.39(\mathrm{~d}, J=7.6$ $\mathrm{Hz}, 6 \mathrm{H}), 7.26(\mathrm{t}, J=7.6 \mathrm{~Hz}, 6 \mathrm{H}), 7.20(\mathrm{t}, J=7.3 \mathrm{~Hz}, 3 \mathrm{H}), 5.91-5.81(\mathrm{~m}, 1 \mathrm{H}), 5.28(\mathrm{dd}, J=17.2$, $1.1 \mathrm{~Hz}, 1 \mathrm{H}), 5.22(\mathrm{~d}, J=11.2 \mathrm{~Hz}, 1 \mathrm{H}), 4.59(\mathrm{~d}, J=5.5 \mathrm{~Hz}, 1 \mathrm{H}), 4.31(\mathrm{~d}, J=6.4 \mathrm{~Hz}, 1 \mathrm{H}), 2.66-2.55$

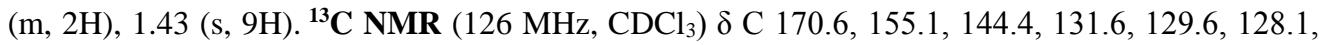
126.9, 118.7, 80.0, 66.9, 66.1, 52.6, 34.2, 28.4. 
Table S1. Synthesis of Pyroacm resin (3a) ${ }^{\mathrm{a}}$.

$\begin{array}{lll} & \\ & & \end{array}$

a $2 \mathbf{a}$ of $3.5 \mathrm{mmol}$ with $7 \mathrm{mmol}$ of additive in THF (20 x w.r.t Merrifield resin) added $3.5 \mathrm{mmol}$ of $2 \mathrm{M}$ Base slowly at $78{ }^{\circ} \mathrm{C}$ for $30 \mathrm{~min}$. After $20 \mathrm{~min}$ added $0.7 \mathrm{mmol}$ of Merrifield resin in single lot. Stirred with long cylindrical stirring bar at $-78{ }^{\circ} \mathrm{C}$ for $1 \mathrm{~h}$ and at $25{ }^{\circ} \mathrm{C}$ for $3 \mathrm{~h}$ (stirring $200 \mathrm{rpm}$ ). ${ }^{b}$ Loading based on measuring fmoc group via fmoc quantitative analysis of immobilized Fmoc-Cys(Trt)-OAllyl on 3a. ${ }^{\mathrm{c}}$ shaker at $160 \mathrm{rpm}$ has been used. ${ }^{\mathrm{d}}$ Process repeated on 3a obtained from entry $7 .{ }^{e} 40$ x THF w.r.t Merrifield resin. ${ }^{f} 10$ x THF w.r.t Merrifield resin.

Pyroacm resin (3a). The $250 \mathrm{~mL}$ RB flask with long cylindrical stirring bar containing $\mathbf{2 a}$ (4.8 g, $37.07 \mathrm{mmol})$ in dry THF $(90 \mathrm{~mL})$ was added to $2 \mathrm{M} \mathrm{LDA}(18.5 \mathrm{~mL}, 37.07 \mathrm{mmol})$ at $-78^{\circ} \mathrm{C}$ for $1 \mathrm{~h}$ under argon atmosphere. The reaction flask brought above the cooling bath for $10 \mathrm{~min}$. Again reaction flask brought back to $-78^{\circ} \mathrm{C}$, after $10 \mathrm{~min}, 2.2 \mathrm{mmol} / \mathrm{g}$ of Merrifield resin (3.37 g, $7.41 \mathrm{mmol}, 100-200$ mess size) was added in 3 portions with 5 min interval between the additions. The reaction condition is maintained at $-78^{\circ} \mathrm{C}$ and $200 \mathrm{rpm}$ for $1 \mathrm{~h}$ and temperature increased slowly to $25^{\circ} \mathrm{C}$, stirred for $4 \mathrm{~h}$. The reaction brought back to $-20{ }^{\circ} \mathrm{C}$ and slowly added $10 \%$ aq $\mathrm{NH}_{4} \mathrm{Cl}$ solution, filtered the solution, washed the resin with THF $(5 \times 50 \mathrm{~mL})$, DMF $(5 \times 50 \mathrm{~mL})$ and $\mathrm{CH}_{2} \mathrm{Cl}_{2}(5 \times 50 \mathrm{~mL})$. Finally, dried under high vacuum for overnight. After $\mathbf{4} \mathbf{a}^{\mathbf{1}}$ installed on $\mathbf{3 a}$, Fmoc quantitative analysis showed loading of $0.84 \mathrm{mmol} / \mathrm{g}$. The dried resin $\mathbf{3 a}$ analyzed by IR spectroscopy, which showed intense peak at $1691 \mathrm{~cm}^{-1}$ and the $100 \mathrm{x}$ magnified image of 3a showed the resin appeared to be normal spherical beads and the irregular shaped beads have not been noticed. 
Table S2. Optimization of trans-thioetherification of cysteine derivative onto Pyroacm resin

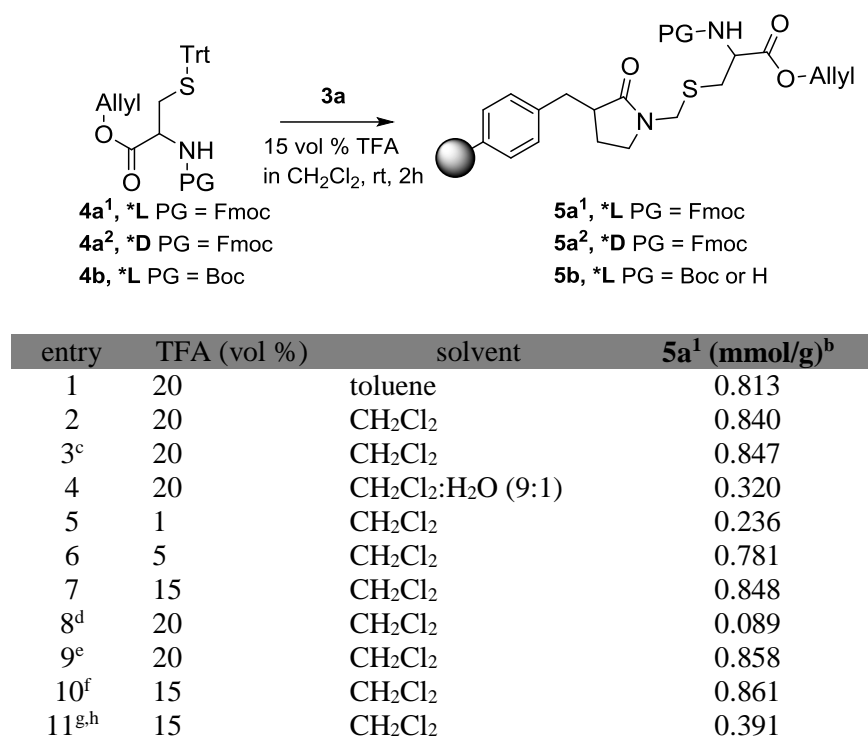

${ }^{a}$ All experiments carried out on $0.1 \mathrm{mmol}$ scale of 3a. ${ }^{\mathrm{b}}$ Loading based on measuring fmoc group on the resin using fmoc quantitative analysis. ${ }^{\mathrm{c}}$ Time is $8 \mathrm{~h} .{ }^{\mathrm{d}} \mathrm{AcOH}$ was used instead of TFA. ${ }^{\mathrm{e}} \mathrm{S}$-Trityl deprotected Fmoc-Cys-OAllyl used instead of $\mathbf{4} \mathbf{a}^{\mathbf{1}} .{ }^{\mathrm{f}} \mathbf{4}^{\mathbf{2}}$ used instead of $\mathbf{4 a}^{\mathbf{1}}$ to obtain $\mathbf{5} \mathbf{a}^{\mathbf{2}}{ }^{\mathrm{g}} \mathbf{4} \mathbf{b}$ used instead of $\mathbf{4} \mathbf{a}^{\mathbf{1}}$ to obtain $\mathbf{5} \mathbf{b}$. ${ }^{\mathrm{h}}$ Loading based on Ninhydrin quantitative analysis.

Fmoc-Cys-L-(Pyroacm -resin)-OAllyl (5a $\left.\mathbf{5}^{\mathbf{1}}\right)$. Pyroacm resin 3a (1 g, $\left.1.82 \mathrm{mmol}\right)$ was taken in $100 \mathrm{~mL}$ RB flask under argon atmosphere. $\mathbf{4 a}^{\mathbf{1}}(3.4 \mathrm{~g}, 5.46 \mathrm{mmol})$ in $\mathrm{CH}_{2} \mathrm{Cl}_{2}(30 \mathrm{~mL})$ was added to the reaction flask. After 15 min, slowly added $8 \mathrm{~mL}$ of TFA into reaction mixture. Reaction mixture shaken for $1.5 \mathrm{~h}$ before filtering resin followed by washing with $\mathrm{CH}_{2} \mathrm{Cl}_{2}(5 \times 20 \mathrm{~mL}) \mathrm{DMF}(5 \times 20 \mathrm{~mL}), \mathrm{CH}_{2} \mathrm{Cl}_{2}(5 \times 20 \mathrm{~mL})$. Before washing the resin with DMF, filtrate evaporated on rotavapour to obtain unreacted $\mathbf{4} \mathbf{a}^{\mathbf{1}}$ quantitatively. Loading of $\mathbf{5 a}^{\mathbf{1}}$ calculated via Fmoc-quantitative analysis was found to be $0.85 \mathrm{mmol} / \mathrm{g}$.

Fmoc-Cys-D-(Pyroacm -resin)-OAllyl (5a $\left.\mathbf{a}^{\mathbf{2}}\right)$. Pyroacm resin 3a $(1 \mathrm{~g}, 1.82 \mathrm{mmol})$ taken in $100 \mathrm{~mL}$ RB flask under argon atmosphere. $4 \mathbf{a}^{2}(3.4 \mathrm{~g}, 5.46 \mathrm{mmol})$ in $\mathrm{CH}_{2} \mathrm{Cl}_{2}(30 \mathrm{~mL})$ was added to the reaction flask. After $15 \mathrm{~min}, 8 \mathrm{~mL}$ of TFA was slowly added into reaction mixture. Reaction mixture shaken for $1.5 \mathrm{~h}$ before filtering resin followed by washing with $\mathrm{CH}_{2} \mathrm{Cl}_{2}(5 \times 20 \mathrm{~mL}) \mathrm{DMF}(5 \times 20 \mathrm{~mL}), \mathrm{CH}_{2} \mathrm{Cl}_{2}(5 \times 20 \mathrm{~mL})$. Before washing the resin with DMF, filtrate evaporated on rotavapour to obtain unreacted $\mathbf{4 a}^{\mathbf{2}}$ quantitatively. Loading of $\mathbf{5} \mathbf{a}^{\mathbf{2}}$ calculated via Fmoc-quantitative analysis was found to be $0.86 \mathrm{mmol} / \mathrm{g}$.

Boc-Cys-L-(Pyroacm -resin)-OAllyl (5b). Pyroacm resin 3a (1 g, $1.82 \mathrm{mmol})$ was taken in $100 \mathrm{~mL}$ RB flask under argon atmosphere. $4 \mathbf{b}(2.7 \mathrm{~g}, 5.46 \mathrm{mmol})$ in $\mathrm{CH}_{2} \mathrm{Cl}_{2}(30 \mathrm{~mL})$ was added to the reaction flask. After $15 \mathrm{~min}$, slowly added $8 \mathrm{~mL}$ of TFA into reaction mixture. Reaction mixture shaken for $2 \mathrm{~h}$ before filtering resin followed by washing with $\mathrm{CH}_{2} \mathrm{Cl}_{2}(5 \times 20 \mathrm{~mL}) \mathrm{DMF}(5 \times 20 \mathrm{~mL}), \mathrm{CH}_{2} \mathrm{Cl}_{2}(5 \times 20 \mathrm{~mL})$. In the crude concentrated filtrate $4 \mathbf{b}$ has not been observed. Loading of $\mathbf{5 b}$ calculated via Ninhydrin-quantitative analysis after treating the small portion of resin with $100 \%$ TFA ( 2 x $2 \mathrm{~min})$ to remove uncleaved Boc, followed by washing with $\mathrm{CH}_{2} \mathrm{Cl}_{2}(5 \times 2 \mathrm{~mL}) \mathrm{DMF}(5 \times 2 \mathrm{~mL}), \mathrm{CH}_{2} \mathrm{Cl}_{2}(5 \times 2 \mathrm{~mL})$ and subsequently treating with DIPEA $(2 \times 5 \mathrm{~min})$ and washing resin with $\mathrm{CH}_{2} \mathrm{Cl}_{2}(5 \times 2 \mathrm{~mL}) \mathrm{DMF}\left(5 \times 2 \mathrm{~mL}^{2}, \mathrm{CH}_{2} \mathrm{Cl}_{2}\right.$ $(5 \times 2 \mathrm{~mL})$. Ninhydrin quantitative analysis showed loading was $0.391 \mathrm{mmol} / \mathrm{g}\left(\varepsilon 1.5 \times 10^{-4}\right.$ considered $)$. 
Synthesis of model peptide onto Pyroacm resin and racemization studies:
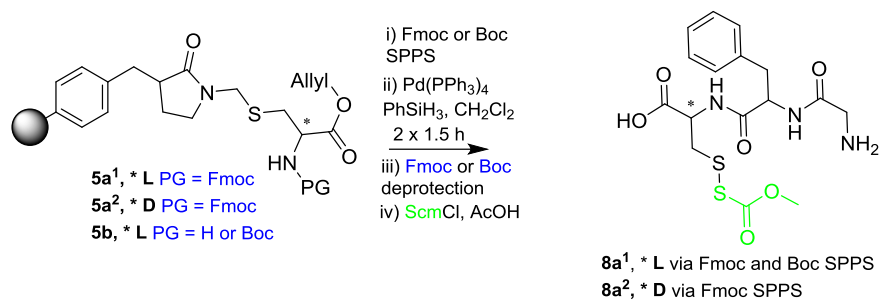

H-Gly-Phe-L-Cys(Scm)-OH (8a $\left.{ }^{1}\right)$ via Fmoc SPPS. Model tripeptide $8 a^{1}$ synthesis started with $\mathbf{5 a}^{\mathbf{1}}$ N-Fmoc deprotection using 20 vol \% piperidine in DMF (2 x 10 min) and subsequent coupling with Fmoc-Phe-OH and FmocGly-OH via standard Fmoc protocol. Allyl group removed by the given method. 20 vol \% piperidine in DMF $(2 \times 10$ $\mathrm{min}$ ) treated with the resin to remove Fmoc group. Finally, $0.02 \mathrm{mmol}$ of resin in $2 \mathrm{~mL}$ of AcOH under argon atmosphere was added 2 equiv of $\mathrm{ScmCl}$ in $1 \mathrm{~mL}$ of $\mathrm{AcOH}$ via syringe. The resin was tumbled at $25^{\circ} \mathrm{C}$ and $160 \mathrm{rpm}$ on shaker for $5 \mathrm{~h}$. The resin was separated by filtration and washed with $\mathrm{AcOH}(2 \times 2 \mathrm{~mL})$. The filtrate was diluted with water (made $20 \%$ aqueous) and lyophilized to obtain crude $\mathbf{8} \mathbf{a}^{1}$. The crude product analysed using HPLC, LCMS and further purified by prepHPLC yielded $\mathbf{8 \mathbf { a } ^ { 1 }}$ as white solid. ESI-MS/MS: for $\mathrm{C}_{16} \mathrm{H}_{21} \mathrm{~N}_{3} \mathrm{O}_{6} \mathrm{~S}_{2}\left[\mathrm{M}+\mathrm{H}^{+}\right]^{+}$; cald 416.0945 , found 416.0961 $\left[\mathrm{M}+\mathrm{Na}^{+}\right]^{+}$; cald 438.0764, found 438.0783.

H-Gly-Phe-D-Cys(Scm)-OH $\left(\mathbf{8 a}^{2}\right)$ via Fmoc SPPS. Model tripeptide 8a ${ }^{2}$ synthesis started with $\mathbf{5 a}^{2}$ N-Fmoc deprotection using 20 vol \% piperidine in DMF ( 2 x 10 min) and subsequent coupling with Fmoc-Phe-OH and FmocGly-OH via standard Fmoc protocol. Allyl group removed by the given method. 20 vol \% piperidine in DMF $(2 \times 10$ $\mathrm{min}$ ) treated with the resin to remove Fmoc group. Finally, $0.02 \mathrm{mmol}$ of resin in $2 \mathrm{~mL}$ of AcOH under argon atmosphere was added 2 equiv of $\mathrm{ScmCl}$ in $1 \mathrm{~mL}$ of $\mathrm{AcOH}$ via syringe. The resin was tumbled at $25^{\circ} \mathrm{C}$ and $160 \mathrm{rpm}$ on shaker for $5 \mathrm{~h}$. The resin was separated by filtration and washed with $\mathrm{AcOH}(2 \times 2 \mathrm{~mL})$. The filtrate was diluted with water (made $20 \%$ aqueous) and lyophilized to obtain crude $\mathbf{8} \mathbf{a}^{2}$. The crude product analysed using HPLC, LCMS and further purified by prepHPLC yielded $\mathbf{8 a ^ { 2 }}$ as white solid. ESI-MS/MS: for $\mathrm{C}_{16} \mathrm{H}_{21} \mathrm{~N}_{3} \mathrm{O}_{6} \mathrm{~S}_{2}\left[\mathrm{M}+\mathrm{H}^{+}\right]^{+}$; cald 416.0945 , found 416.0955 $\left[\mathrm{M}+\mathrm{Na}^{+}\right]^{+}$; cald 438.0764, found 438.0777.

H-Gly-Phe-L-Cys(Scm)-OH ( $\mathbf{8 a}^{1}$ ) via Boc SPPS. Model tripeptide $\mathbf{8 a}^{\mathbf{1}}$ synthesis started with $\mathbf{5 b}$ in which traces of remaining N-Boc deprotection using 100\% TFA ( 2 × 2 min) and subsequent coupling with Boc-Phe-OH and Boc-Gly$\mathrm{OH}$ via standard Boc protocol. Allyl group removed by the given method. 100\% TFA ( 2 x 2 min) treated with resin to remove Boc group. Finally, $0.02 \mathrm{mmol}$ of resin in $2 \mathrm{~mL}$ of AcOH under argon atmosphere was added 2 equiv of $\mathrm{ScmCl}$ in $1 \mathrm{~mL}$ of AcOH via syringe. The resin was tumbled at $25^{\circ} \mathrm{C}$ and $160 \mathrm{rpm}$ on shaker for $5 \mathrm{~h}$. The resin was separated by filtration and washed with $\mathrm{AcOH}(2 \times 2 \mathrm{~mL})$. The filtrate was diluted with water (made $20 \%$ aqueous) and lyophilized to obtain crude $\mathbf{8 a ^ { 1 }}$. The crude product analysed using HPLC, LCMS and further purified by prepHPLC yielded $\mathbf{8} \mathbf{a}^{\mathbf{1}}$ as white solid. ESI-MS/MS: for $\mathrm{C}_{16} \mathrm{H}_{21} \mathrm{~N}_{3} \mathrm{O}_{6} \mathrm{~S}_{2}\left[\mathrm{M}+\mathrm{H}^{+}\right]^{+}$; cald 416.0945, found $416.0943\left[\mathrm{M}+\mathrm{Na}^{+}\right]^{+}$; cald 438.0764, found 438.0761 .

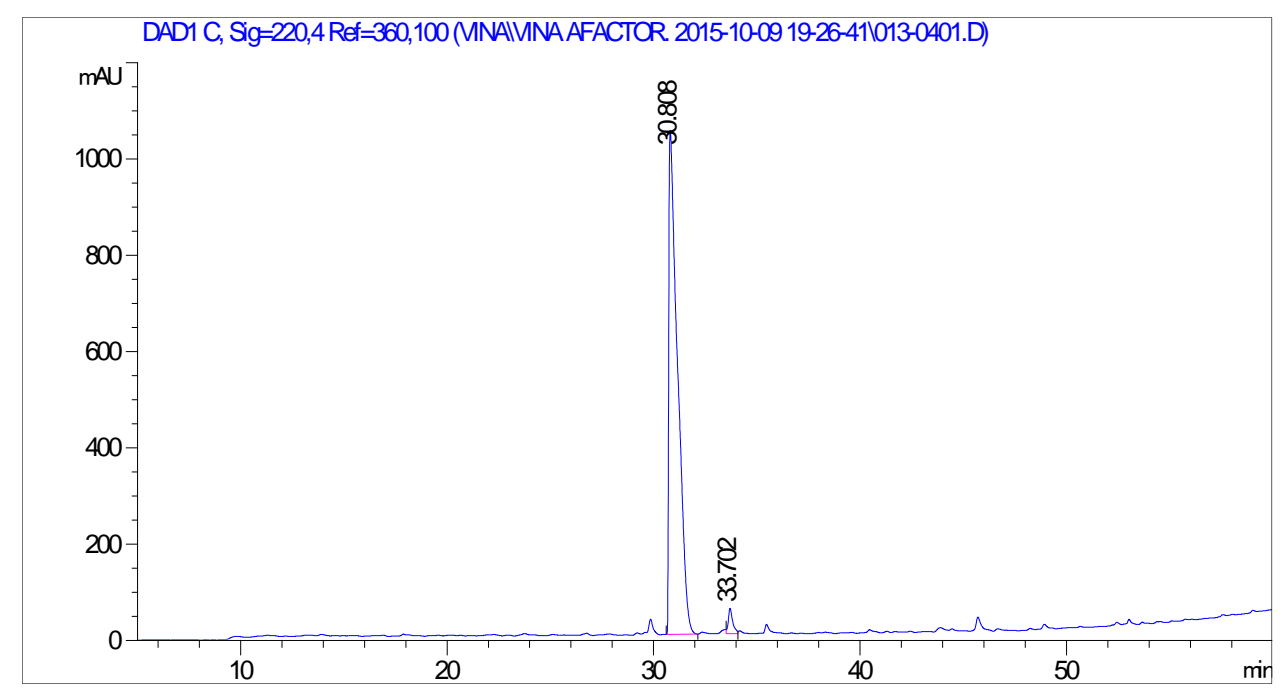

Figure S1: Crude HPLC data of H-Gly-Phe-L-Cys(Scm)-OH ( $\left.\mathbf{8 a}^{\mathbf{1}}\right)$ via Fmoc SPPS 


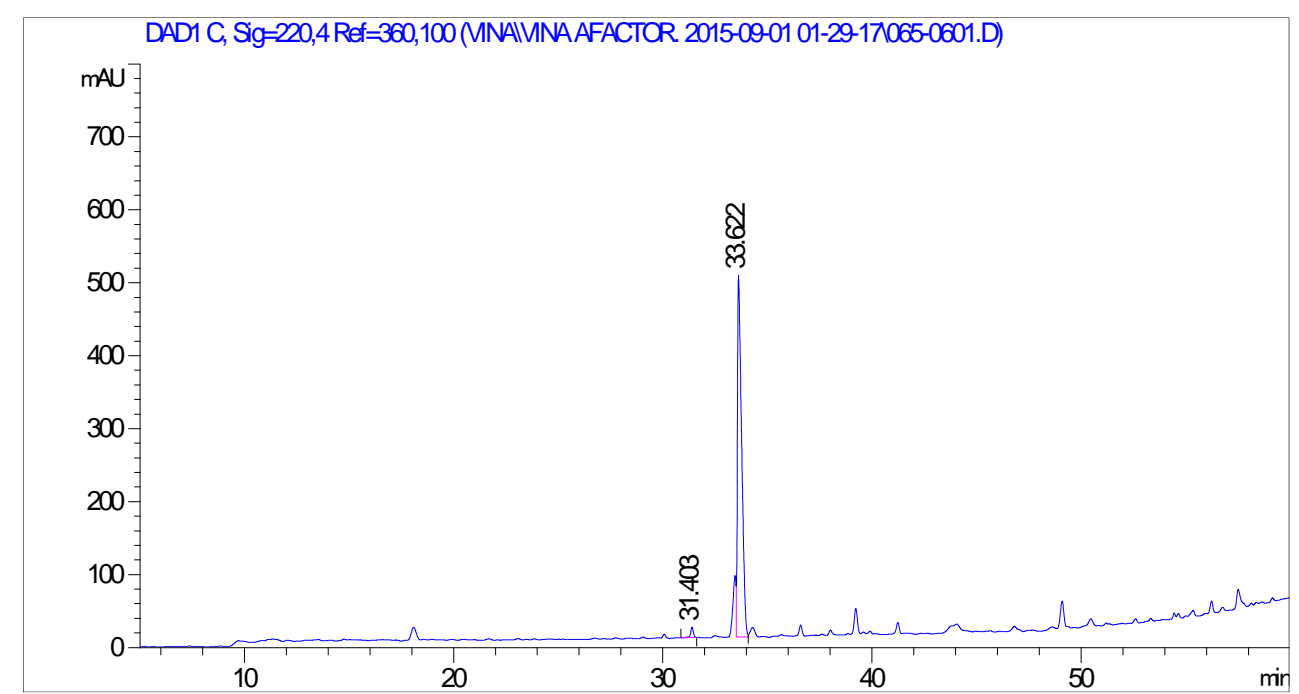

Figure S2: Crude HPLC data of H-Gly-Phe-D-Cys(Scm)-OH ( $\left.\mathbf{8 a}^{\mathbf{2}}\right)$ via Fmoc SPPS

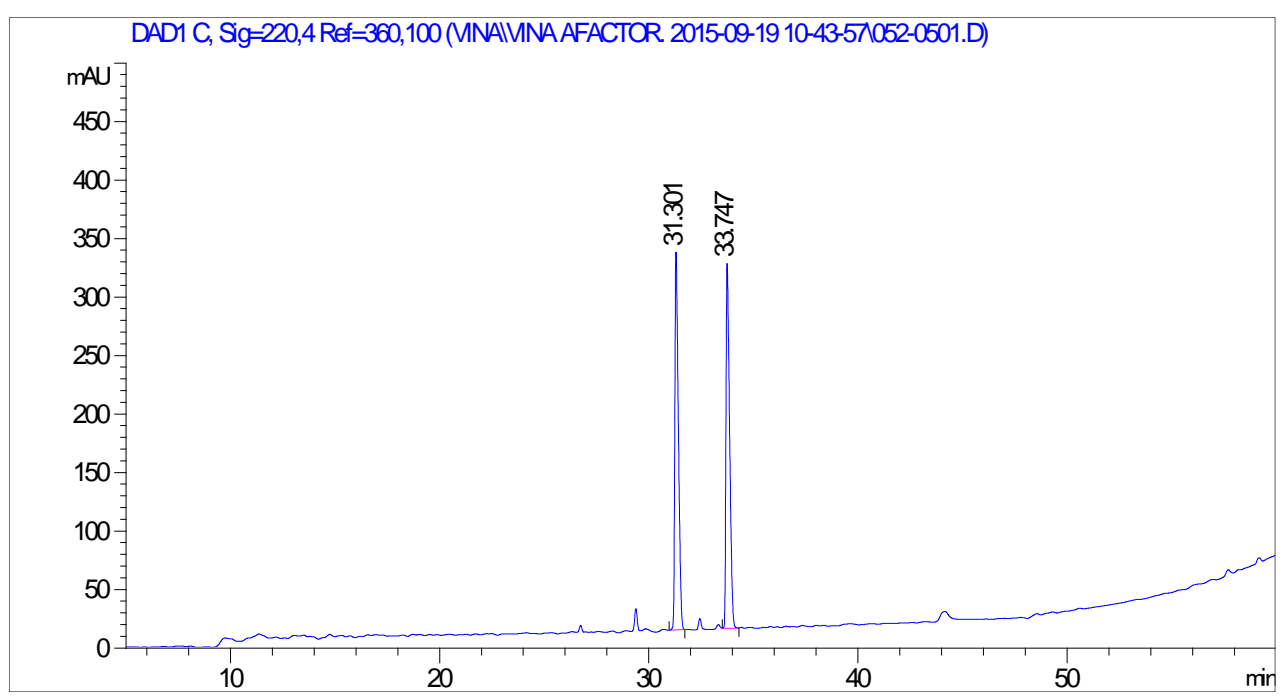

Figure S3: Pure HPLC coinjected data of H-Gly-Phe-L-Cys(Scm)-OH ( $\left.\mathbf{8 a}^{\mathbf{1}}\right)$ and H-Gly-Phe-D-Cys(Scm)-OH $\left(\mathbf{8 a}^{\mathbf{2}}\right)$ via Fmoc SPPS

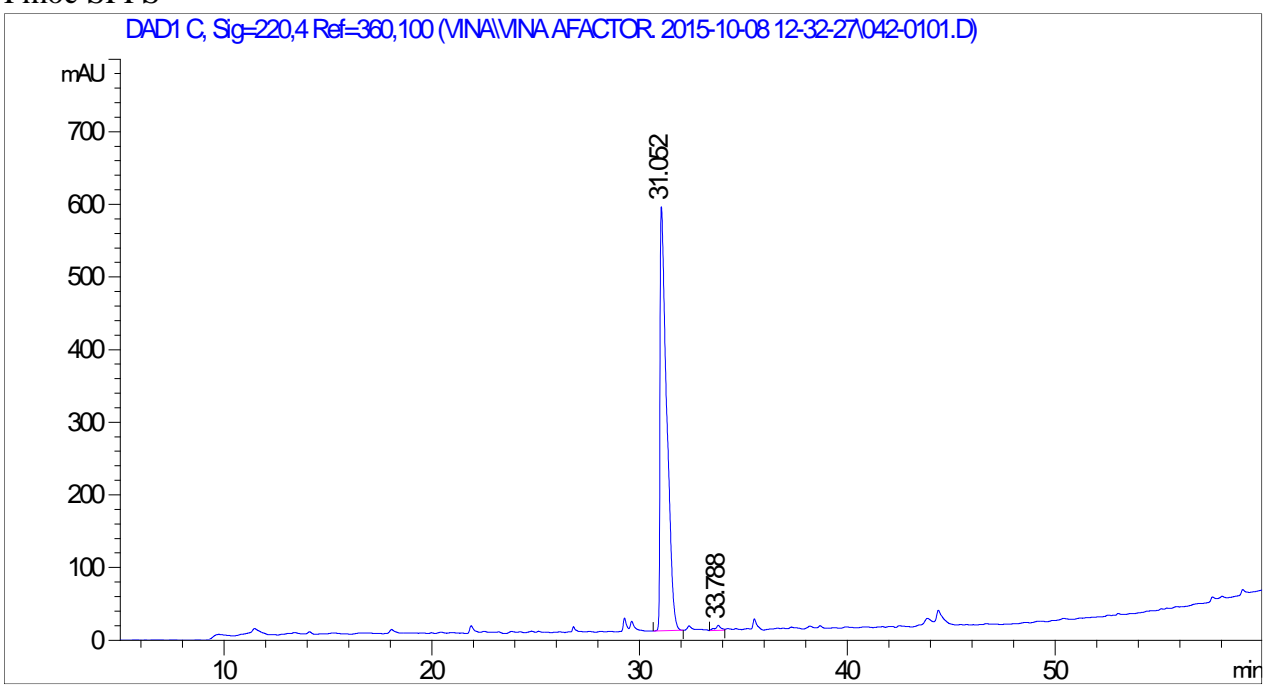

Figure S4: Crude HPLC data of H-Gly-Phe-L-Cys(Scm)-OH (8a $\left.\mathbf{1}^{\mathbf{1}}\right)$ via Boc SPPS 
Table S3: Stability of Pyoacm resin attached to Fmoc-Gly-Phe-L-Cys-OAllyl (6a $\left.{ }^{1}\right)$ towards piperidine $^{\mathrm{a}}$ :

$\begin{array}{cccc}\text { entry } & \text { reagent } & \text { reaction time } & \mathbf{6 a}^{\mathbf{1}}(\mathbf{m m o l} / \mathbf{g})^{\mathbf{b}} \\ 1 & 20 \text { vol \% piperidine } & 15 \mathrm{~min} & 0.293 \\ 2 & 20 \text { vol \% piperidine } & 1 \mathrm{~h} & 0.251 \\ 3 & 20 \text { vol \% piperidine } & 6 \mathrm{~h} & 0.257 \\ 4 & 20 \text { vol \% piperidine } & 24 \mathrm{~h} & 0.194\end{array}$

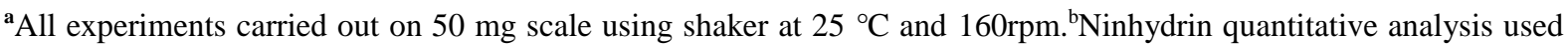
for the quantification of amine group on the resin, during calculation $\varepsilon 1.5 \times 10^{-4}$ considered.

Table S4: Stability of Pyroacm resin attached to Fmoc-Gly-Phe-L-Cys-OAllyl $\left(6 \mathbf{a}^{1}\right)$ under acidic conditions ${ }^{\mathrm{a}}$ :

$\begin{array}{cccc}\text { entry } & \text { reagent } & \text { reaction time } & \mathbf{6 a}^{\mathbf{1}}(\mathbf{m m o l} / \mathbf{g})^{\mathbf{b}} \\ 1 & \text { TFA: } \mathrm{CH}_{2} \mathrm{Cl}_{2}(1: 1) & 1 \mathrm{~h} & 0.520 \\ 2 & \text { TFA: } \mathrm{CH}_{2} \mathrm{Cl}_{2}(1: 1) & 8 \mathrm{~h} & 0.488 \\ 3 & \text { TFA: } \mathrm{CH}_{2} \mathrm{Cl}_{2}(1: 1) & 24 \mathrm{~h} & 0.473 \\ 4 & \text { TFA } & 1 \mathrm{~h} & 0.497 \\ 5 & \text { TFA } & 8 \mathrm{~h} & 0.480 \\ 6^{\mathrm{c}} & \text { Reagent K } & 1 \mathrm{~h} & 0.489 \\ 7^{\mathrm{c}} & \text { Reagent K } & 8 \mathrm{~h} & 0.473 \\ 8^{\mathrm{d}} & \text { Reagent B } & 1 \mathrm{~h} & 0.500 \\ 9^{\mathrm{d}} & \text { Reagent B } & 8 \mathrm{~h} & 0.462\end{array}$

${ }^{a}$ All experiments carried out on resin of $50 \mathrm{mg}$ scale using shaker at $25{ }^{\circ} \mathrm{C}$ and $160 \mathrm{rpm} .{ }^{\mathrm{b}} \mathrm{Fmoc}$ quantitative analysis used for the quantification of Fmoc group on the resin. ${ }^{c}$ Reagent $\mathrm{K}$ is (TFA: $\mathrm{H}_{2} \mathrm{O}$ :thioanisole:phenol:EDT) of $(82.5: 5: 5: 5: 2.5)$ ratio. ${ }^{d}$ Reagent $\mathrm{B}$ is (TFA: $\mathrm{H}_{2} \mathrm{O}$ :TIPS:phenol) of $(88: 5: 2: 5)$ ratio. 
Scheme 4. Synthesis of a Riparin 1.2

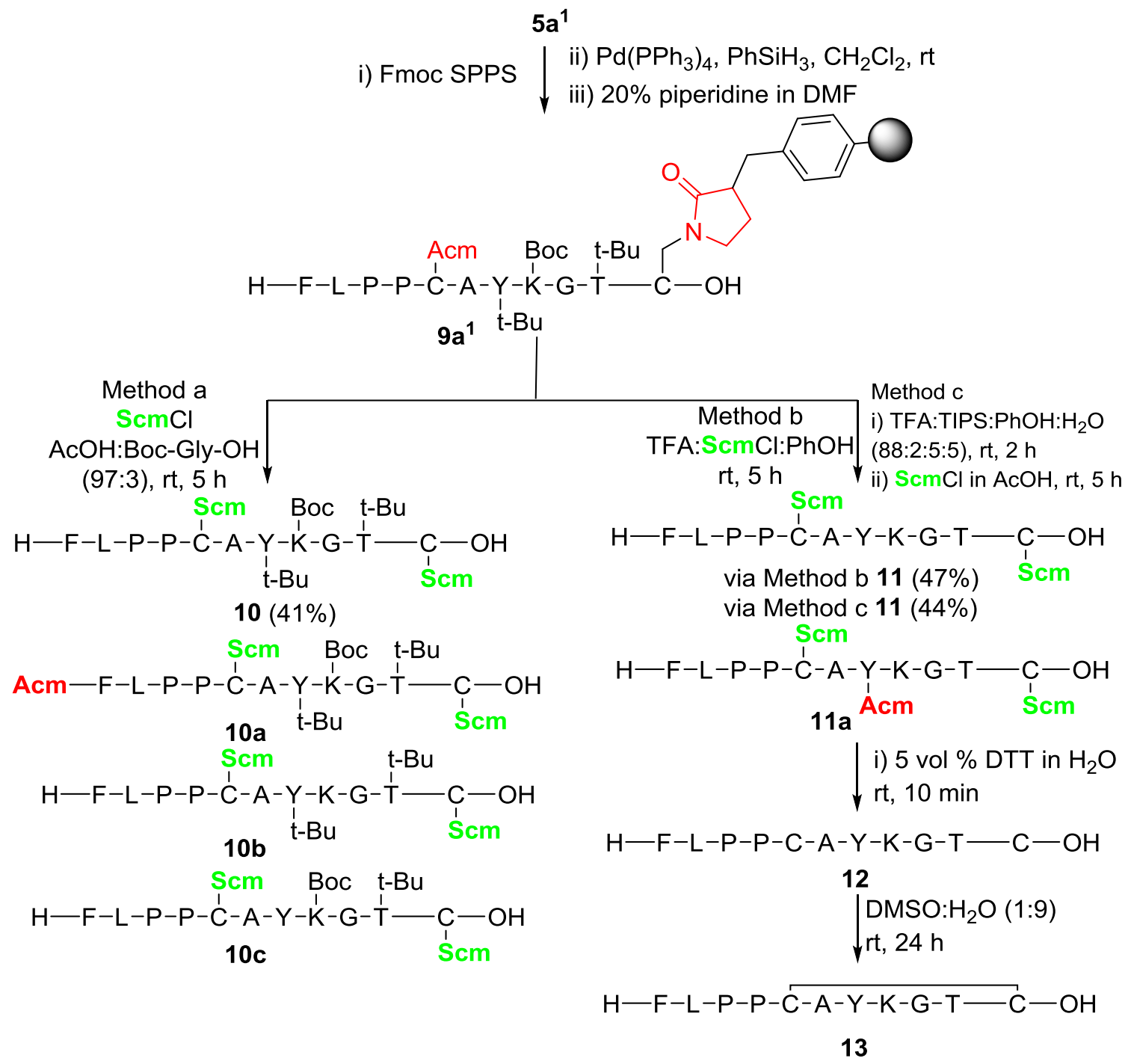




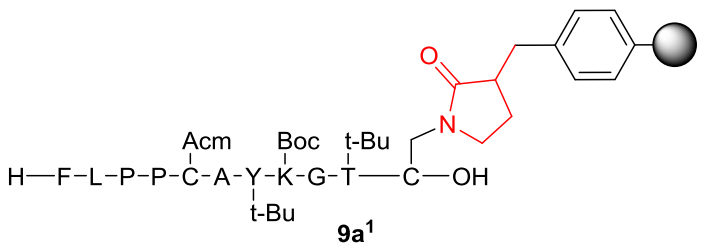

To obtain intermediate $\mathbf{9} \mathbf{a}^{\mathbf{1}}$, the synthesis started with Fmoc cleavage of $\mathbf{5 a}^{\mathbf{1}}$ using 20 vol $\%$ of piperidine in DMF wherein Fmoc SPPS protocol used to couple Fmoc-Thr(t-Bu)-OH, Fmoc-Gly-OH, Fmoc-Lys(Boc)-OH, Fmoc-Tyr(t-Bu)-OH, Fmoc-Ala-OH, Fmoc-Cys(Acm)-OH, twice Fmoc-Pro-OH, Fmoc-Leu-OH and Fmoc-Phe-OH respectively. 20\% piperidine in DMF $(2 \times 10 \mathrm{~min})$ treated with resin to remove Fmoc group. Allyl group removed by given method followed by Fmoc-removal with standard protocol

Synthesis of side chain protected di-sulfenyl Riparin $1.2(10)$ :

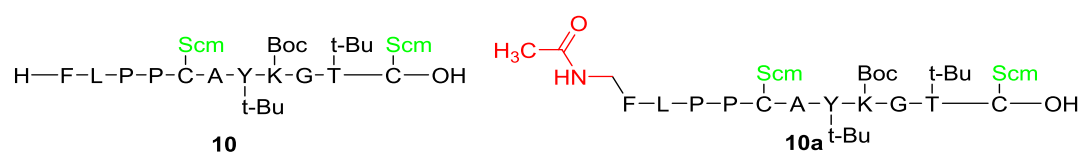

To obtain 10, resin $\mathbf{9} \mathbf{a}^{\mathbf{1}}$ of $0.02 \mathrm{mmol}$ in $5 \mathrm{~mL}$ of AcOH:Boc-Gly-OH of ratio (97:3) for 15 min under argon atmosphere, followed by slow addition of $\mathrm{ScmCl}$ (4 equiv) in $\mathrm{AcOH}(1 \mathrm{~mL})$ via syringe. The resin was tumbled at $25^{\circ} \mathrm{C}$ and 160 $\mathrm{rpm}$ on shaker for $5 \mathrm{~h}$. The resin was separated by filtration and the resin washed with AcOH $(2 \times 2 \mathrm{~mL})$. The filtrate was diluted with water (made $20 \%$ aqueous) and lyophilized, giving a residue that subjected to analysis by HPLC, LCMS and the crude purified by prepHPLC. (Note: when $\mathrm{CH}_{2} \mathrm{Cl}_{2}$ was used as a solvent, the filtrate was concentrated on rotavapour at $30{ }^{\circ} \mathrm{C}$ ). After PrepHPLC followed by lyophilization product was obtained $\mathbf{1 0}$ as white solid (12 mg, 41\%). ESI-MS/MS: for $\mathrm{C}_{72} \mathrm{H}_{110} \mathrm{~N}_{12} \mathrm{O}_{20} \mathrm{~S}_{4}\left[\mathrm{M}+\mathrm{H}^{+}\right]^{+}$; cald 1591.6915 , found $1591.6904\left[\mathrm{M}+\mathrm{Na}^{+}\right]^{+}$; cald 1613.6734 , found 1613.6714

Synthesis of side chain de-protected di-sulfenyl Riparin 1.2 (11) via method (b):

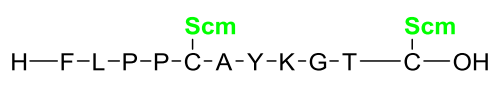

11

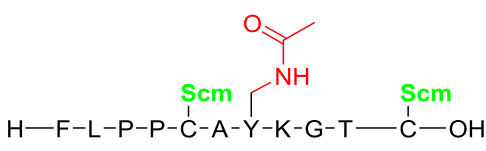

11a

To obtain 11, resin $9 \mathbf{a}^{1}$ of $0.02 \mathrm{mmol}$ was added $3 \mathrm{~mL}$ cocktail containing TFA:PhOH:ScmCl of ratio (94.75:5:0.25), stirred at $25{ }^{\circ} \mathrm{C}$ and $400 \mathrm{rpm}$ for $5 \mathrm{~h}$. The reaction mass filtered and washed with TFA $(2 \mathrm{x} 1 \mathrm{~mL})$. Cold ether $\left(-20^{\circ} \mathrm{C}\right)$ was slowly added to the filtrate at $-10^{\circ} \mathrm{C}$. The solution was left overnight in the freezer, centrifuged and the pellets were dissolved in $\mathrm{H}_{2} \mathrm{O} / \mathrm{ACN}$ (1:1) for the crude analysis using HPLC and LCMS. After PrepHPLC purification followed by lyophilization obtained 11 as white solid (11.9 mg, 47\%). ESI-MS/MS: for $\mathrm{C}_{59} \mathrm{H}_{86} \mathrm{~N}_{12} \mathrm{O}_{18} \mathrm{~S}_{4}\left[\mathrm{M}+\mathrm{H}^{+}\right]^{+}$; cald 1379.5139, found $1379.5130\left[\mathrm{M}+\mathrm{Na}^{+}\right]^{+}$; cald 1401.4958 , found 1401.4925

Synthesis of side chain de-protected di-sulfenyl Riparin 1.2 (11) via method (c):

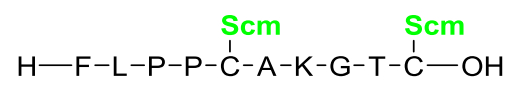

To obtain 11, resin $\mathbf{9} \mathbf{a}^{\mathbf{1}}$ of $0.02 \mathrm{mmol}$ was swollen in $3 \mathrm{~mL}$ of TFA:PhOH: $\mathrm{H}_{2} \mathrm{O}:$ TIPS of ratio (88:5:5:2), stirred for $2 \mathrm{~h}$, filtered and washed with TFA $(1 \times 1 \mathrm{~min})$ and $\mathrm{CH}_{2} \mathrm{Cl}_{2}(10 \times 2 \mathrm{~min})$. The dried resin was swollen in $5 \mathrm{~mL}$ of AcOH for 15 min under argon atmosphere followed by slow addition of $\mathrm{ScmCl}$ (4 equiv.) in $\mathrm{AcOH}(1 \mathrm{~mL})$ via syringe. The resin was tumbled in shaker at $25{ }^{\circ} \mathrm{C}$ and $160 \mathrm{rpm}$ for $5 \mathrm{~h}$, filtered and the resin was washed with $\mathrm{AcOH}(2 \times 2 \mathrm{~mL})$. The filtrate was made $20 \%$ aqueous by addition of water and lyophilized to give the residue that was dissolved in $\mathrm{H}_{2} \mathrm{O} / \mathrm{ACN}$ (1:1) for analysis using HPLC and LCMS. After PrepHPLC purification followed by lyophilization obtained 11 as white solid (12.1 mg, 44\%). ESI-MS/MS: for $\mathrm{C}_{59} \mathrm{H}_{86} \mathrm{~N}_{12} \mathrm{O}_{18} \mathrm{~S}_{4}\left[\mathrm{M}+\mathrm{H}^{+}\right]^{+}$; cald 1379.5139, found1379.5126 [M+Na ${ }^{+}$; cald 1401.4958 , found 1401.4926 
Synthesis of reduced Riparin 1.2 (12): The crude 11 from 0.002 mmol of $\mathbf{9 a} \mathbf{a}^{\mathbf{1}}$ via method $\mathrm{b}$, has been taken in argon purged $1 \mathrm{~mL}$ of 5 vol \% DTT(ca., 100 equiv) in $\mathrm{H}_{2} \mathrm{O}$, added $\mathrm{ACN}$ dropwise to obtain homogenous mixture. After 10 min, subjected to HPLC purification, obtained 12 of purity $95 \%$ containing $\mathbf{5 \%}$ of $\mathbf{1 7}$. ESI-MS/MS: for $\mathrm{C}_{55} \mathrm{H}_{82} \mathrm{~N}_{12} \mathrm{O}_{14} \mathrm{~S}_{2}$ $\left[\mathrm{M}+\mathrm{H}^{+}\right]^{+}$; cald 1199.5588, found $1199.5579\left[\mathrm{M}+\mathrm{Na}^{+}\right]^{+}$; cald 1221.5407 , found 1221.5392

Synthesis of Riparin 1.2 (13): 12 was taken in $900 \mathrm{x}$ of $\mathrm{H}_{2} \mathrm{O}$ under air, ACN has been added dropwise until homogenous mixture obtained. 10 vol \% DMSO has been added into reaction mixture and the reaction mass was stirred at rt for nearly $24 \mathrm{~h}$. The reaction has been monitored on LCMS. HPLC purification has been carried out for purification to obtain white solid 13 of purity $96 \%$ via HPLC. ESI-MS/MS: for $\mathrm{C}_{55} \mathrm{H}_{80} \mathrm{~N}_{12} \mathrm{O}_{14} \mathrm{~S}_{2}\left[\mathrm{M}+\mathrm{H}^{+}\right]^{+}$; cald 1197.5431, found 1197.5420 $\left[\mathrm{M}+\mathrm{Na}^{+}\right]^{+}$; cald 1219.5250 , found 1219.524

Scheme S1. Solid-Phase Synthesis of a Riparin 1.1 with Different protective group strategy:

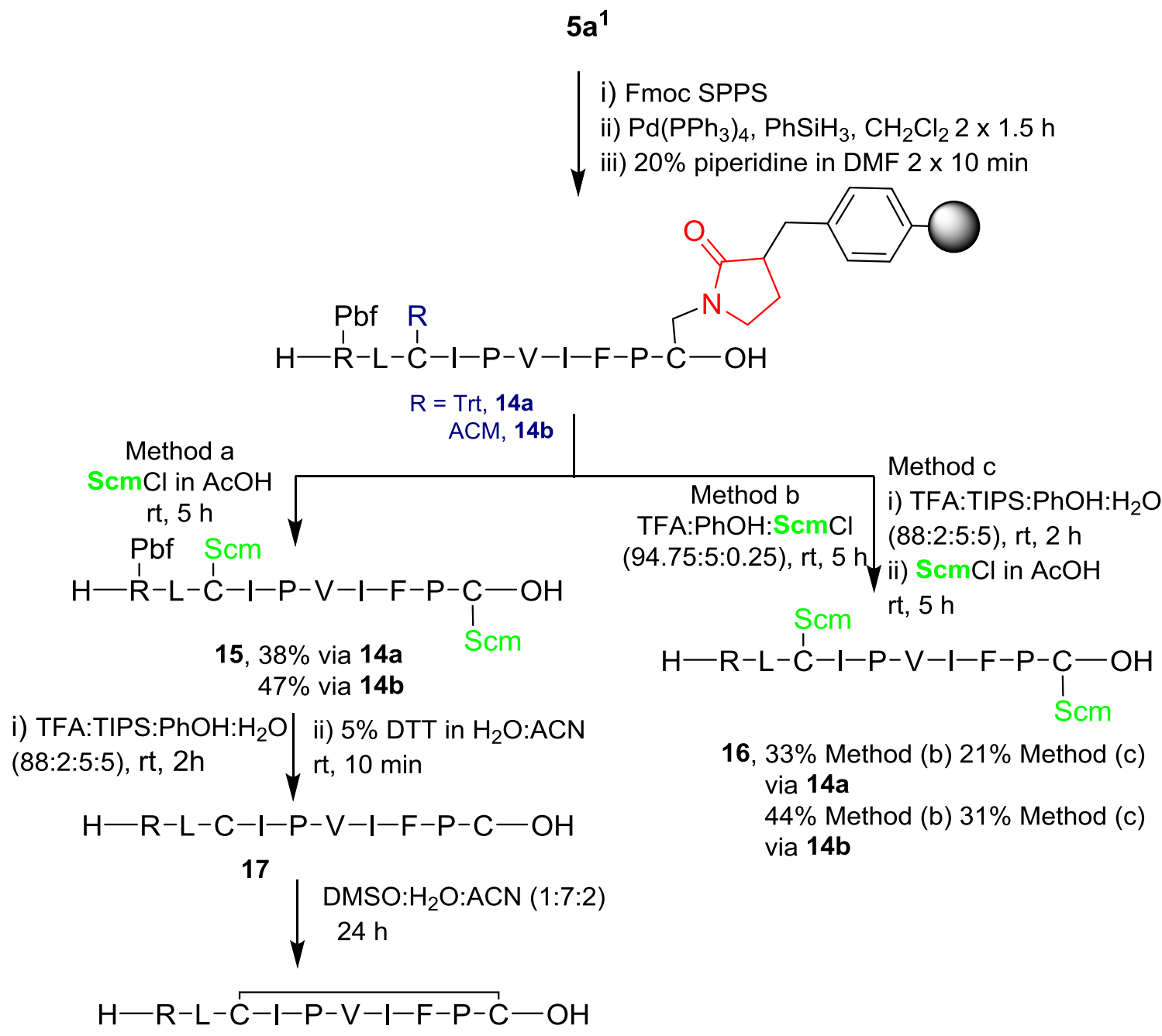




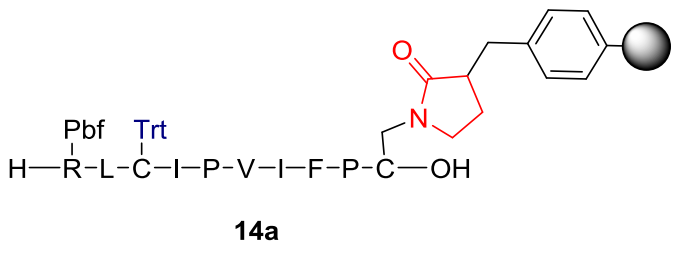

For the synthesis of intermediate 14a, the synthesis started with Fmoc cleavage of $\mathbf{5} \mathbf{a}^{\mathbf{1}}$ using 20 vol \% of piperidine in DMF wherein Fmoc SPPS protocol used to couple Fmoc-Pro-OH, Fmoc-Phe-OH, Fmoc-Ile-OH, Fmoc-Val-OH, FmocPro-OH, Fmoc-Ile-OH, Fmoc-Cys(Trt)-OH, Fmoc-Leu-OH, Fmoc-Arg(Pbf)-OH respectively. 20\% piperidine in DMF ( 2 x $10 \mathrm{~min}$ ) treated to resin to remove Fmoc group. Allyl group removed by given method followed by Fmoc-removal with standard protocol

\section{Synthesis of intermediate Riparin 1.1 resin $(14 b)$ :}

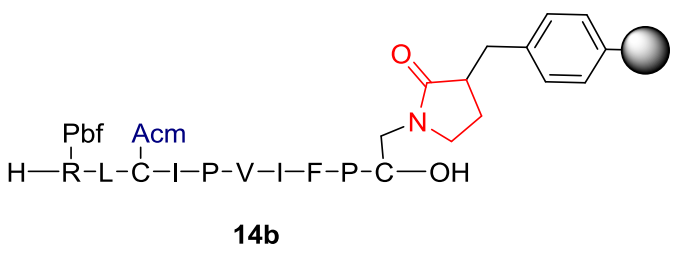

For the synthesis of intermediate $\mathbf{1 4 b}$, the synthesis started with Fmoc cleavage of $\mathbf{5 a}^{\mathbf{1}}$ using 20 vol \% of piperidine in DMF wherein Fmoc SPPS protocol used to couple Fmoc-Pro-OH, Fmoc-Phe-OH, Fmoc-Ile-OH, Fmoc-Val-OH, FmocPro-OH, Fmoc-Ile-OH, Fmoc-Cys(Acm)-OH, Fmoc-Leu-OH, Fmoc-Arg(Pbf)-OH respectively. 20\% piperidine in DMF ( 2 x $10 \mathrm{~min})$ treated to resin to remove Fmoc group. Allyl group removed by given method followed by Fmocremoval with standard protocol

\section{Synthesis of side chain protected di-sulfenyl Riparin 1.1 (15) via 14a:}

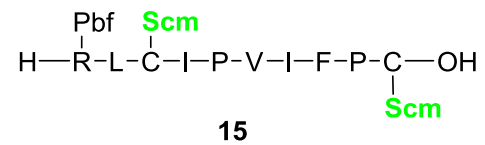

To obtain 15, resin 14a of $0.02 \mathrm{mmol}$ in $5 \mathrm{~mL}$ of $\mathrm{AcOH}$ for $15 \mathrm{~min}$ under argon atmosphere, followed by slow addition of $\mathrm{ScmCl}$ (4 equiv) in $\mathrm{AcOH}(1 \mathrm{~mL})$ via syringe. The resin was tumbled at $25{ }^{\circ} \mathrm{C}$ and $160 \mathrm{rpm}$ on shaker for $5 \mathrm{~h}$. The resin was separated by filtration and the resin washed with $\mathrm{AcOH}(2 \times 2 \mathrm{~mL})$. The filtrate was diluted with water (made $20 \%$ aqueous) and lyophilized, giving a residue that subjected to analysis by HPLC, LCMS and the crude purified by prepHPLC. After PrepHPLC followed by lyophilization product was obtained as white solid (11 mg, 38\%). ESI-MS/MS: for $\mathrm{C}_{71} \mathrm{H}_{109} \mathrm{~N}_{13} \mathrm{O}_{18} \mathrm{~S}_{5}\left[\mathrm{M}+\mathrm{H}^{+}\right]^{+}$; cald 1592.6689, found $1592.6685\left[\mathrm{M}+\mathrm{Na}^{+}\right]^{+}$; cald 1614.6509 , found 1614.6507

\section{Synthesis of side chain protected di-sulfenyl Riparin 1.1 (15) via 14b:}

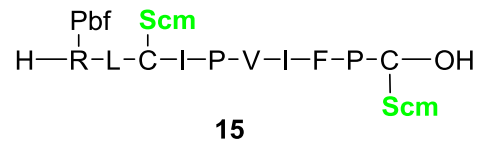

To obtain 15, resin $\mathbf{1 4 b}$ of $0.02 \mathrm{mmol}$ in $5 \mathrm{~mL}$ of $\mathrm{AcOH}$ for $15 \mathrm{~min}$ under argon atmosphere, followed by slow addition of $\mathrm{ScmCl}$ (4 equiv) in $\mathrm{AcOH}(1 \mathrm{~mL})$ via syringe. The resin was tumbled at $25{ }^{\circ} \mathrm{C}$ and $160 \mathrm{rpm}$ on shaker for $5 \mathrm{~h}$. The resin was separated by filtration and the resin washed with $\mathrm{AcOH}(2 \times 2 \mathrm{~mL})$. The filtrate was diluted with water (made $20 \%$ aqueous) and lyophilized, giving a residue that subjected to analysis by HPLC, LCMS and the crude purified by prepHPLC. After PrepHPLC followed by lyophilization product was obtained as white solid (13.7 mg, 47\%). ESIMS/MS: for $\mathrm{C}_{71} \mathrm{H}_{109} \mathrm{~N}_{13} \mathrm{O}_{18} \mathrm{~S}_{5}\left[\mathrm{M}+\mathrm{H}^{+}\right]^{+}$; cald 1592.6689 , found $1592.6682\left[\mathrm{M}+\mathrm{Na}^{+}\right]^{+}$; cald 1614.6509 , found 1614.6503 
Synthesis of reduced Riparin 1.1 (17): The crude 16 was subjected to general labile thiol-sulfenyl deprotection method used in case of Riparin 1.2 and subjected to HPLC purification obtained 17 of purity 95\%. ESI-MS/MS: for $\mathrm{C}_{54} \mathrm{H}_{89} \mathrm{~N}_{13} \mathrm{O}_{11} \mathrm{~S}_{2}\left[\mathrm{M}+\mathrm{H}^{+}\right]^{+}$; cald 1160.6319 , found $1160.6370\left[\mathrm{M}+\mathrm{Na}^{+}\right]^{+}$; cald 1182.6138 , found 1182.6122

Synthesis of Riparin 1.1 (18): 17 was taken in $900 \mathrm{x} \mathrm{H}_{2} \mathrm{O}$ under air and $\mathrm{ACN}$ was added dropwise until homogenous mixture attained. $10 \%$ DMSO $(\mathrm{v} / \mathrm{v})$ has been added into reaction mixture and the reaction mass was stirred at $\mathrm{rt}$ for nearly $24 \mathrm{~h}$. The reaction has been monitored on LCMS. HPLC purification yielded white solid $\mathbf{1 8}$ of purity $96 \%$ via

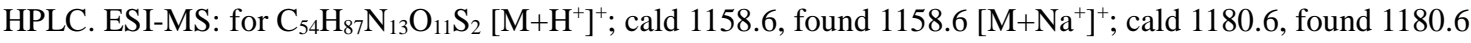

Synthesis of side chain de-protected di-sulfenyl Riparin 1.1 (16) using method (b) via 14a:

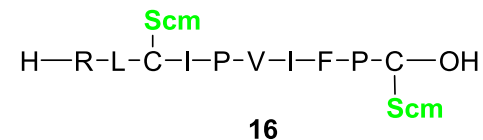

Cleavage of resin 14a of $0.02 \mathrm{mmol}$ was added $3 \mathrm{~mL}$ cocktail containing TFA:PhOH:ScmCl of ratio (94.75:5:0.25), stirred at $25{ }^{\circ} \mathrm{C}$ and $400 \mathrm{rpm}$ for $5 \mathrm{~h}$. The reaction mass filtered and washed with TFA $(2 \mathrm{x} 1 \mathrm{~mL})$. Cold ether $\left(-20^{\circ} \mathrm{C}\right)$ was slowly added to the filtrate at $-10^{\circ} \mathrm{C}$. The solution was left overnight in the freezer, centrifuged and the pellets were dissolved in $\mathrm{H}_{2} \mathrm{O} / \mathrm{ACN}$ (1:1) for the crude analysis using HPLC and LCMS. After PrepHPLC purification followed by lyophilization obtained 16 as white solid (8.1 mg, 33\%). ESI-MS/MS: for $\mathrm{C}_{58} \mathrm{H}_{93} \mathrm{~N}_{13} \mathrm{O}_{15} \mathrm{~S}_{4}\left[\mathrm{M}+\mathrm{H}^{+}\right]^{+}$; cald 1340.5870, found $1340.5861\left[\mathrm{M}+\mathrm{Na}^{+}\right]^{+}$; cald 1362.5689 , found 1362.5658

Synthesis of side chain de-protected di-sulfenyl Riparin 1.1 (16) using method (b) via 14b:

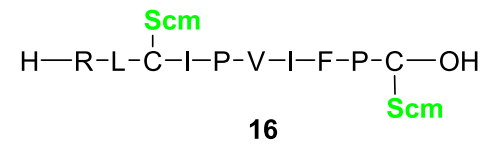

Cleavage of resin 14b of $0.02 \mathrm{mmol}$ was added $3 \mathrm{~mL}$ cocktail containing TFA:PhOH:ScmCl of ratio (94.75:5:0.25), stirred at $25{ }^{\circ} \mathrm{C}$ and $400 \mathrm{rpm}$ for $5 \mathrm{~h}$. The reaction mass filtered and washed with TFA $(2 \mathrm{x} 1 \mathrm{~mL})$. Cold ether $\left(-20^{\circ} \mathrm{C}\right)$ was slowly added to the filtrate at $-10^{\circ} \mathrm{C}$. The solution was left overnight in the freezer, centrifuged and the pellets were dissolved in $\mathrm{H}_{2} \mathrm{O} / \mathrm{ACN}$ (1:1) for the crude analysis using HPLC and LCMS. After PrepHPLC purification followed by lyophilization obtained 16 as white solid (10.8 mg, 44\%). ESI-MS/MS: for $\mathrm{C}_{58} \mathrm{H}_{93} \mathrm{~N}_{13} \mathrm{O}_{15} \mathrm{~S}_{4}\left[\mathrm{M}+\mathrm{H}^{+}\right]^{+}$; cald 1340.5870 , found $1340.5860\left[\mathrm{M}+\mathrm{Na}^{+}\right]^{+}$; cald 1362.5689 , found 1362.5657

Synthesis of side chain de-protected di-sulfenyl Riparin 1.1 (16) using method (c) via 14a:

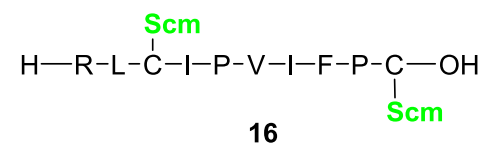

Cleavage of resin 14a of $0.02 \mathrm{mmol}$ was swollen in $3 \mathrm{~mL}$ of TFA:PhOH: $\mathrm{H}_{2} \mathrm{O}:$ TIPS of ratio (88:5:5:2), stirred for $2 \mathrm{~h}$, filtered and washed with TFA $(1 \times 1 \mathrm{~min})$ and $\mathrm{CH}_{2} \mathrm{Cl}_{2}(10 \times 2 \mathrm{~min})$. The dried resin was swollen in $5 \mathrm{~mL}$ of $\mathrm{AcOH}$ for 15 min under argon atmosphere followed by slow addition of $\mathrm{ScmCl}$ (4 equiv.) in $\mathrm{AcOH}(1 \mathrm{~mL})$ via syringe. The resin was tumbled in shaker at $25{ }^{\circ} \mathrm{C}$ and $160 \mathrm{rpm}$ for $5 \mathrm{~h}$, filtered and the resin was washed with AcOH $(2 \mathrm{x} 2 \mathrm{~mL})$. The filtrate was made $20 \%$ aqueous by addition of water and then lyophilized giving a residue that was dissolved in $\mathrm{H}_{2} \mathrm{O} / \mathrm{ACN}$ (1:1) for analysis using HPLC and LCMS. After PrepHPLC purification followed by lyophilization obtained 16 as white solid (5.7 mg, 21\%). ESI-MS/MS: for $\mathrm{C}_{58} \mathrm{H}_{93} \mathrm{~N}_{13} \mathrm{O}_{15} \mathrm{~S}_{4}\left[\mathrm{M}+\mathrm{H}^{+}\right]^{+} ; 1340.5870$, found $1340.5863\left[\mathrm{M}+\mathrm{Na}^{+}\right]^{+}$; cald 1362.5689 , found 1362.5661 
Synthesis of side chain de-protected di-sulfenyl Riparin 1.1 (16) using method (c) via 14b:

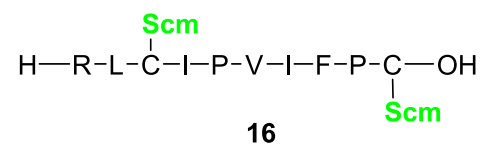

Cleavage of resin 14b of $0.02 \mathrm{mmol}$ was swollen in $3 \mathrm{~mL}$ of TFA:PhOH: $\mathrm{H}_{2} \mathrm{O}:$ TIPS of ratio (88:5:5:2), stirred for $2 \mathrm{~h}$, filtered and washed with TFA (1 x $1 \mathrm{~min})$ and $\mathrm{CH}_{2} \mathrm{Cl}_{2}(10 \times 2 \mathrm{~min})$. The dried resin was swollen in $5 \mathrm{~mL}$ of $\mathrm{AcOH}$ for 15 min under argon atmosphere followed by slow addition of $\mathrm{ScmCl}$ (4 equiv.) in $\mathrm{AcOH}(1 \mathrm{~mL})$ via syringe. The resin was tumbled in shaker at $25{ }^{\circ} \mathrm{C}$ and $160 \mathrm{rpm}$ for $5 \mathrm{~h}$, filtered and the resin was washed with AcOH $(2 \times 2 \mathrm{~mL})$. The filtrate was made $20 \%$ aqueous by addition of water and then lyophilized giving a residue that was dissolved in $\mathrm{H}_{2} \mathrm{O} / \mathrm{ACN}$ (1:1) for analysis using HPLC and LCMS. After PrepHPLC purification followed by lyophilization obtained 16 as white solid (8.4 mg, 31\%). ESI-MS/MS: for $\mathrm{C}_{58} \mathrm{H}_{93} \mathrm{~N}_{13} \mathrm{O}_{15} \mathrm{~S}_{4}\left[\mathrm{M}+\mathrm{H}^{+}\right]^{+}$; 1340.5870 , found $1340.5857\left[\mathrm{M}+\mathrm{Na}^{+}\right]^{+}$; cald 1362.5689 , found 1362.5655

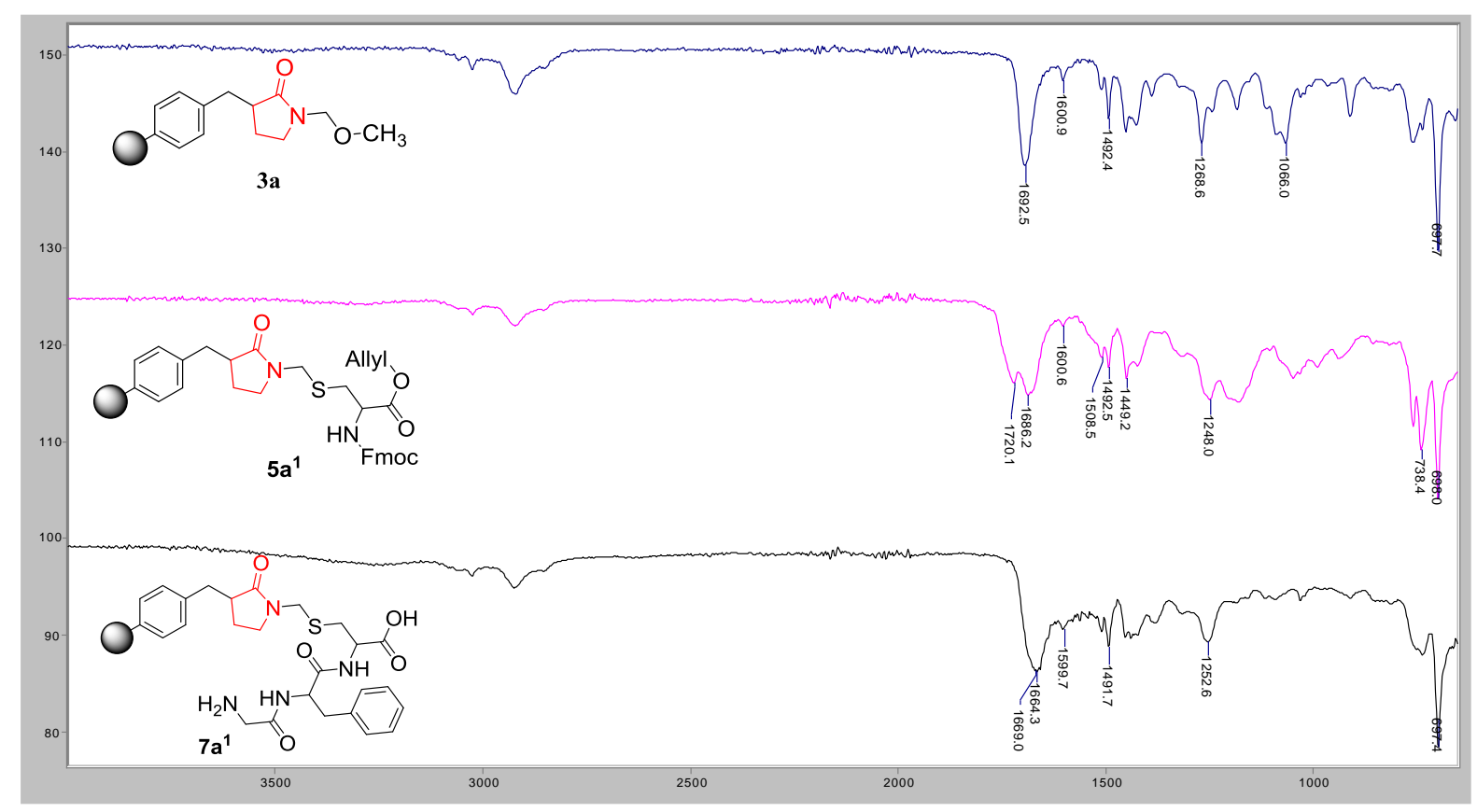

Figure S5: Representative ATR-FTIR spectrum of corresponding resins 
Synthesis of side chain protected di-sulfenyl Riparin $1.2(10)$ :

A) Characterisation of 10 (Table 1, entry 1):

DAD1 G, Sig=220,4Ref=360,100(MNAIVNAAFACTCR 2015-11-01 11-52-521033-0301.D)
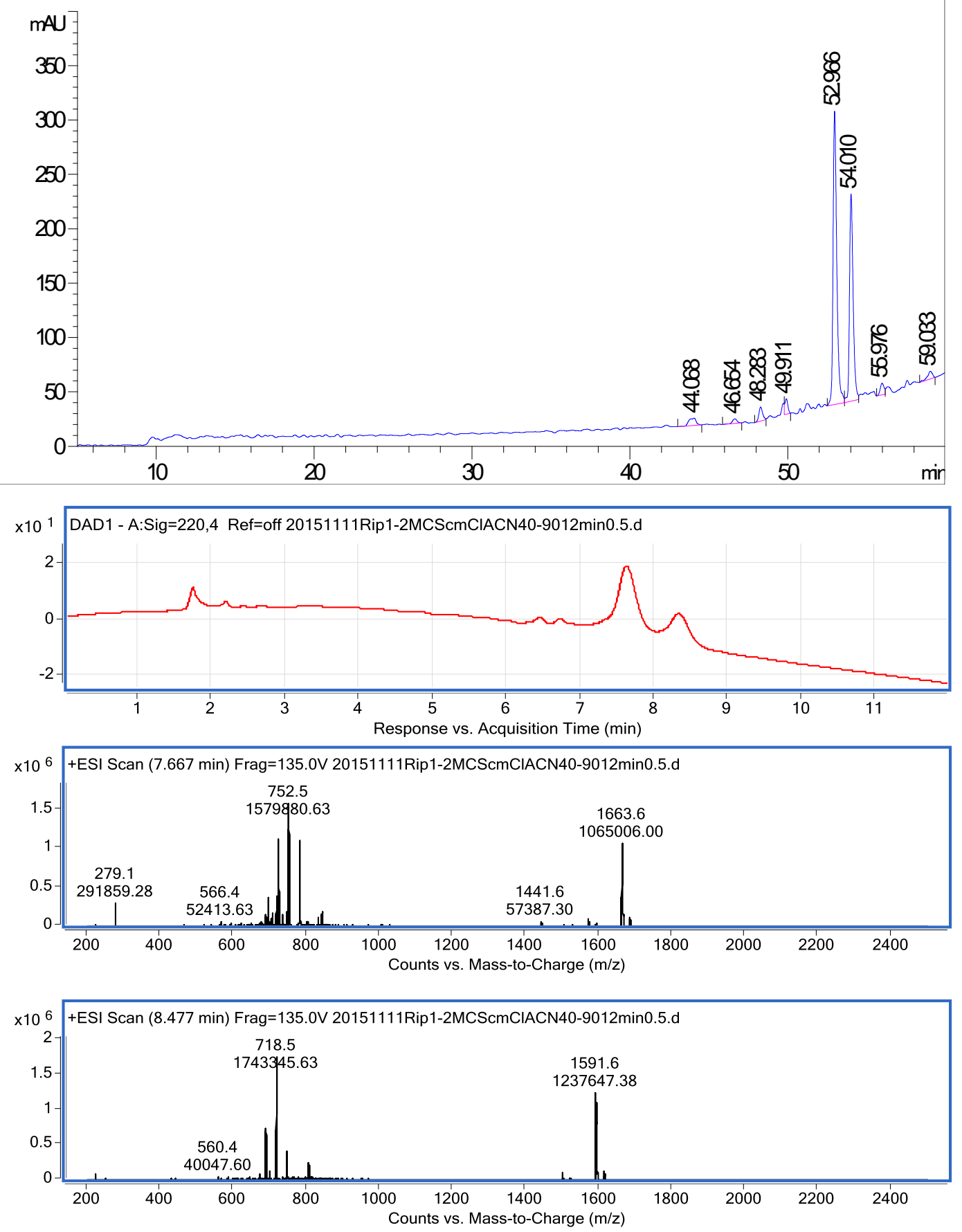

Figure S6: Crude HPLC and LCMS chromatograms for cleavage of $\mathbf{9 a}^{\mathbf{1}}$ with 4 equiv of $\mathrm{ScmCl}$ in $\mathrm{CH}_{2} \mathrm{Cl}_{2}$. $\mathrm{LCMS}$ trace retention times based on linear gradient from $40 \%$ to $90 \%$ ACN over 12 min 
B) Characterisation of 10 (Table 1, entry 2):
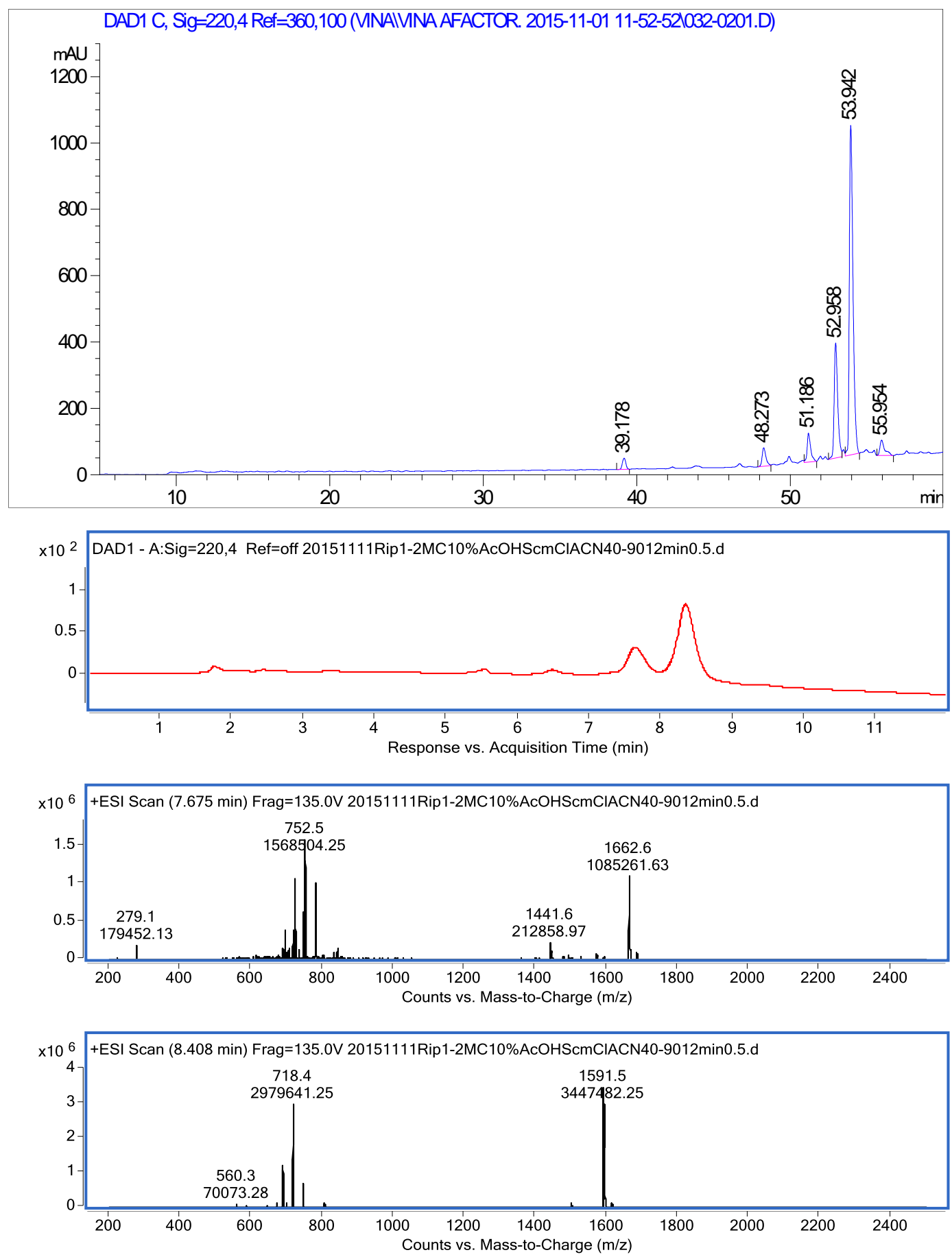

Figure S7: Crude HPLC and LCMS chromatograms for cleavage of $\mathbf{9} \mathbf{a}^{\mathbf{1}}$ with 4 equiv of $\mathrm{ScmCl}$ in $\mathrm{AcOH}: \mathrm{CH}_{2} \mathrm{Cl}_{2}(1: 9)$. LCMS trace retention times based on linear gradient from 40\% to 90\% ACN over 12 min 
C) Characterisation of 10 (Table 1, entry 3)
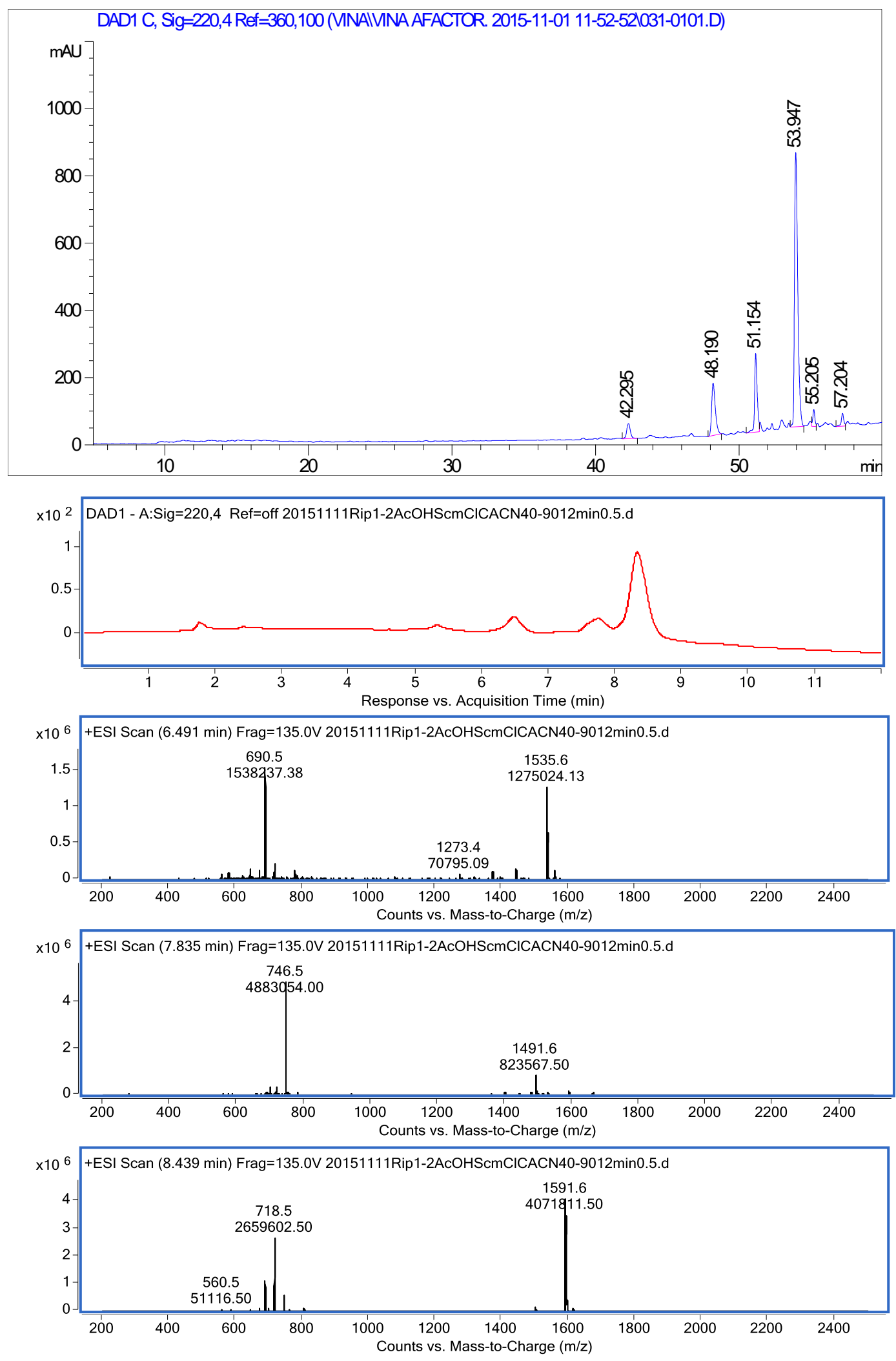

Figure S8: Crude HPLC and LCMS chromatograms for cleavage of $\mathbf{9 a}^{\mathbf{1}}$ with 4 equiv of $\mathrm{ScmCl}$ in AcOH. LCMS trace retention times based on linear gradient from $40 \%$ to $90 \%$ ACN over $12 \mathrm{~min}$ 
D) Characterisation of 10 (Table 1, entry 5)
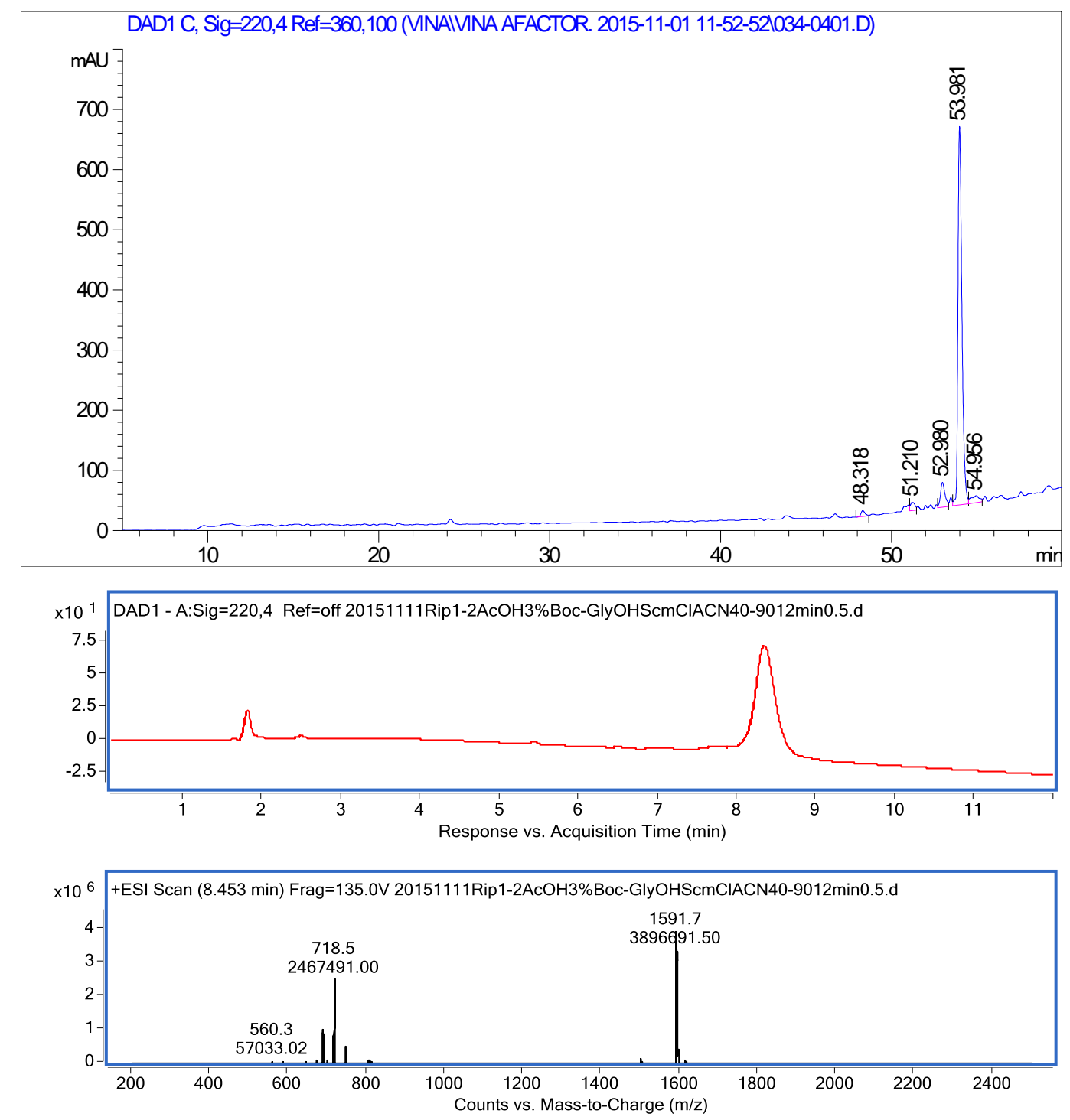

Figure S9: Crude HPLC and LCMS chromatograms for cleavage of $\mathbf{9 \mathbf { a } ^ { 1 }}$ with 4 equiv of $\mathrm{ScmCl}$ in AcOH:Boc-Gly-OH (97:3). LCMS trace retention times based on linear gradient from $40 \%$ to $90 \% \mathrm{ACN}$ over $12 \mathrm{~min}$ 
Synthesis of side chain de-protected di-sulfenyl Riparin 1.2 (11) via method (b):

A) Characterisation of 11 (Table 2, entry 1)

DAD1 C, Sig=220,4 Ref=360,100 (VINAIVINA AFACTOR. 2015-11-1821-58-57/012-0201.D)
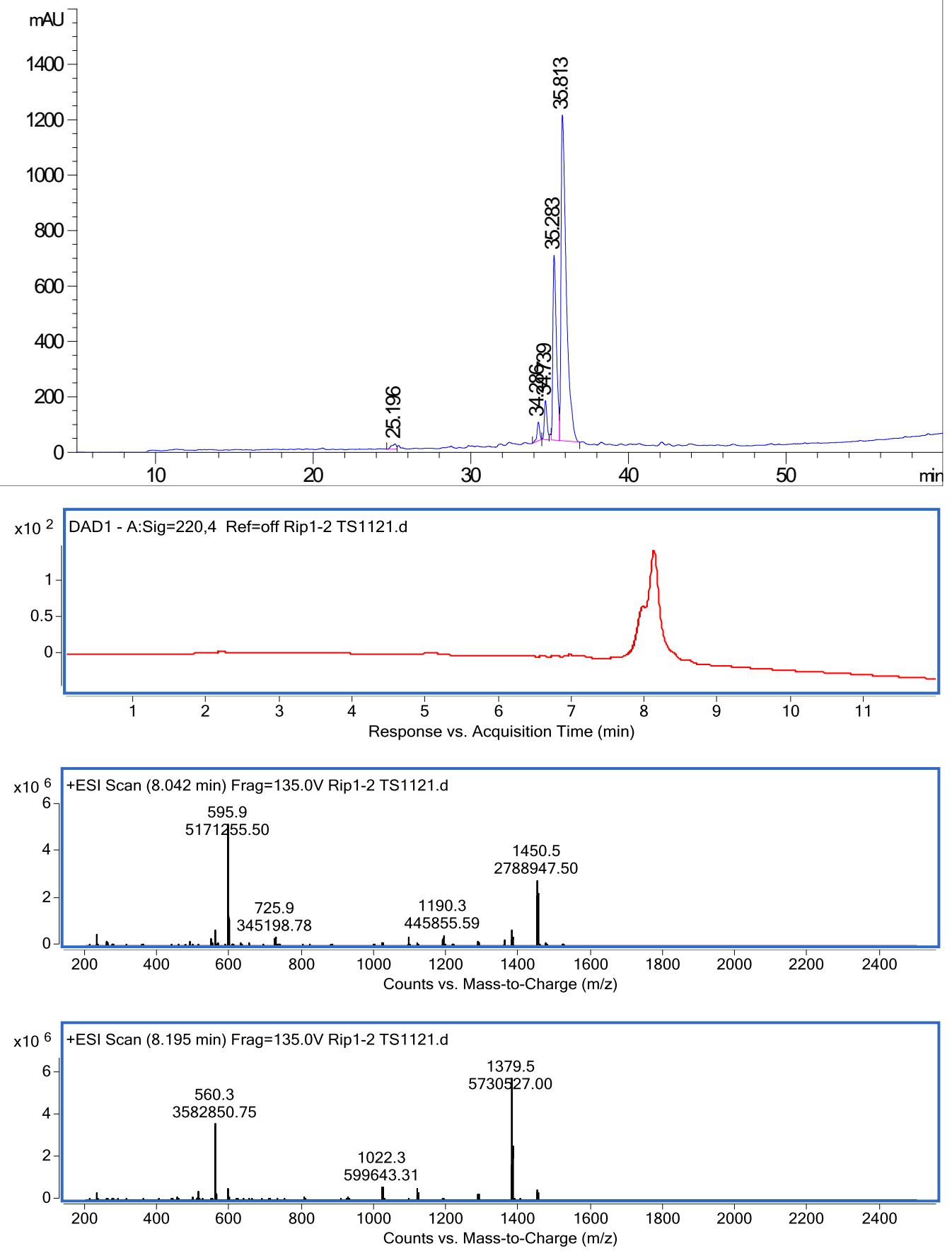

Figure S10: Crude HPLC and LCMS chromatograms for cleavage of $9 \mathbf{a}^{\mathbf{1}}$ with 4 equiv of $\mathrm{ScmCl}$ in TFA:ScmCl(99.75:0.25:5). LCMS trace retention times based on linear gradient from 20\% to 90\% ACN over 12 min 


\section{B) Characterization of 11 (Table 2, entry 4)}
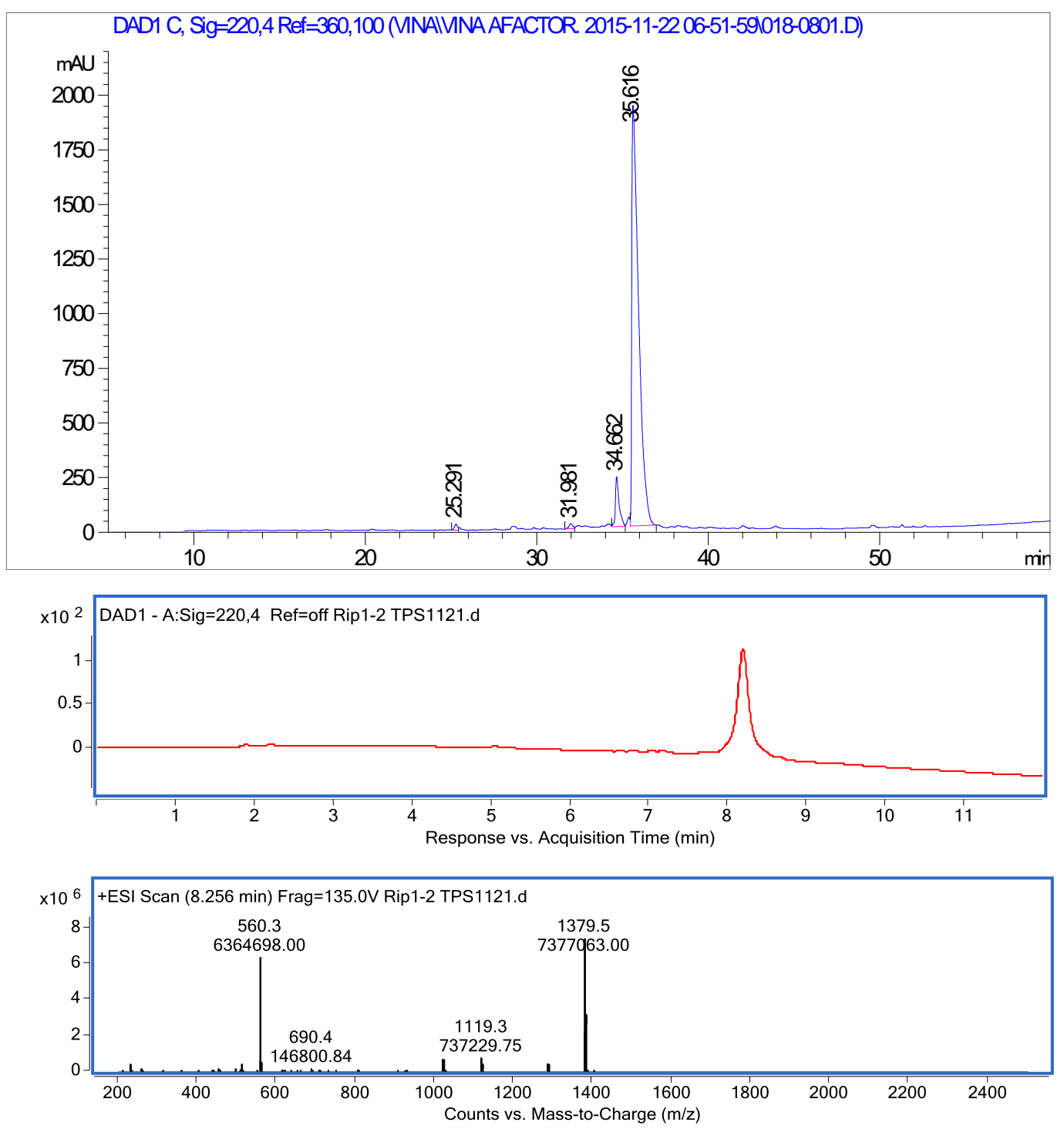

Figure S11: Crude HPLC and LCMS chromatograms for cleavage of $\mathbf{9 a}^{\mathbf{1}}$ with 4 equiv of $\mathrm{ScmCl}$ in TFA:ScmCl:PhOH (94.75:0.25:5). LCMS trace retention times based on linear gradient from $20 \%$ to $90 \%$ ACN over 12 min 
Synthesis of side chain de-protected di-sulfenyl Riparin 1.2 (11) via method (c):
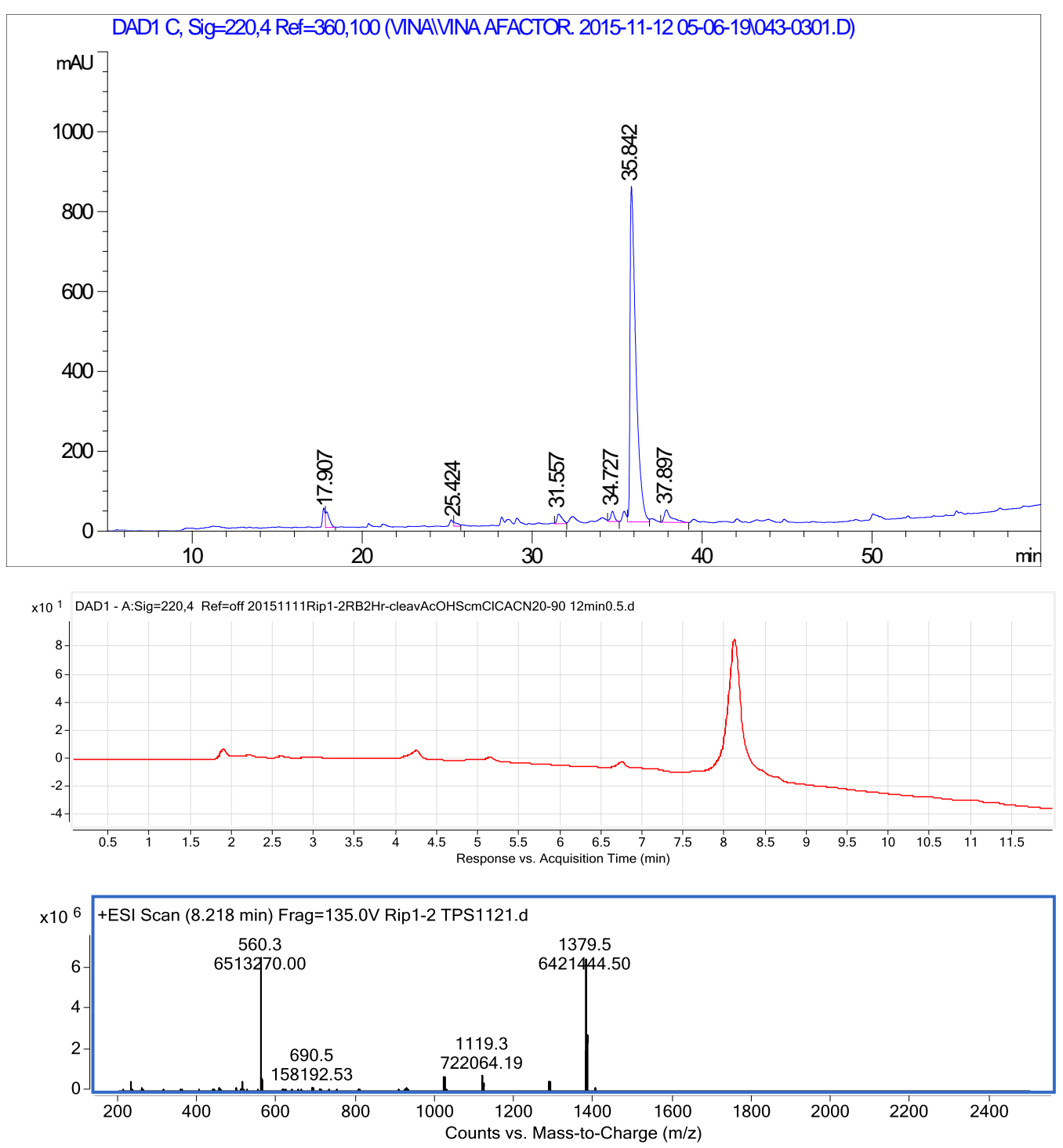

Figure S12: Crude HPLC and LCMS chromatograms for cleavage of $\mathbf{9 a ^ { 1 }}$ with a) TFA:TIPS: $\mathrm{H}_{2} \mathrm{O}: \mathrm{PhOH}(88: 2: 5: 5) 2 \mathrm{~h}$, b) 4 equiv of $\mathrm{ScmCl}$ in $\mathrm{AcOH}$. LCMS trace retention times based on linear gradient from $20 \%$ to $90 \% \mathrm{ACN}$ over 12 $\min$ 
Synthesis of side chain protected di-sulfenyl Riparin 1.1 (15) via 14a:
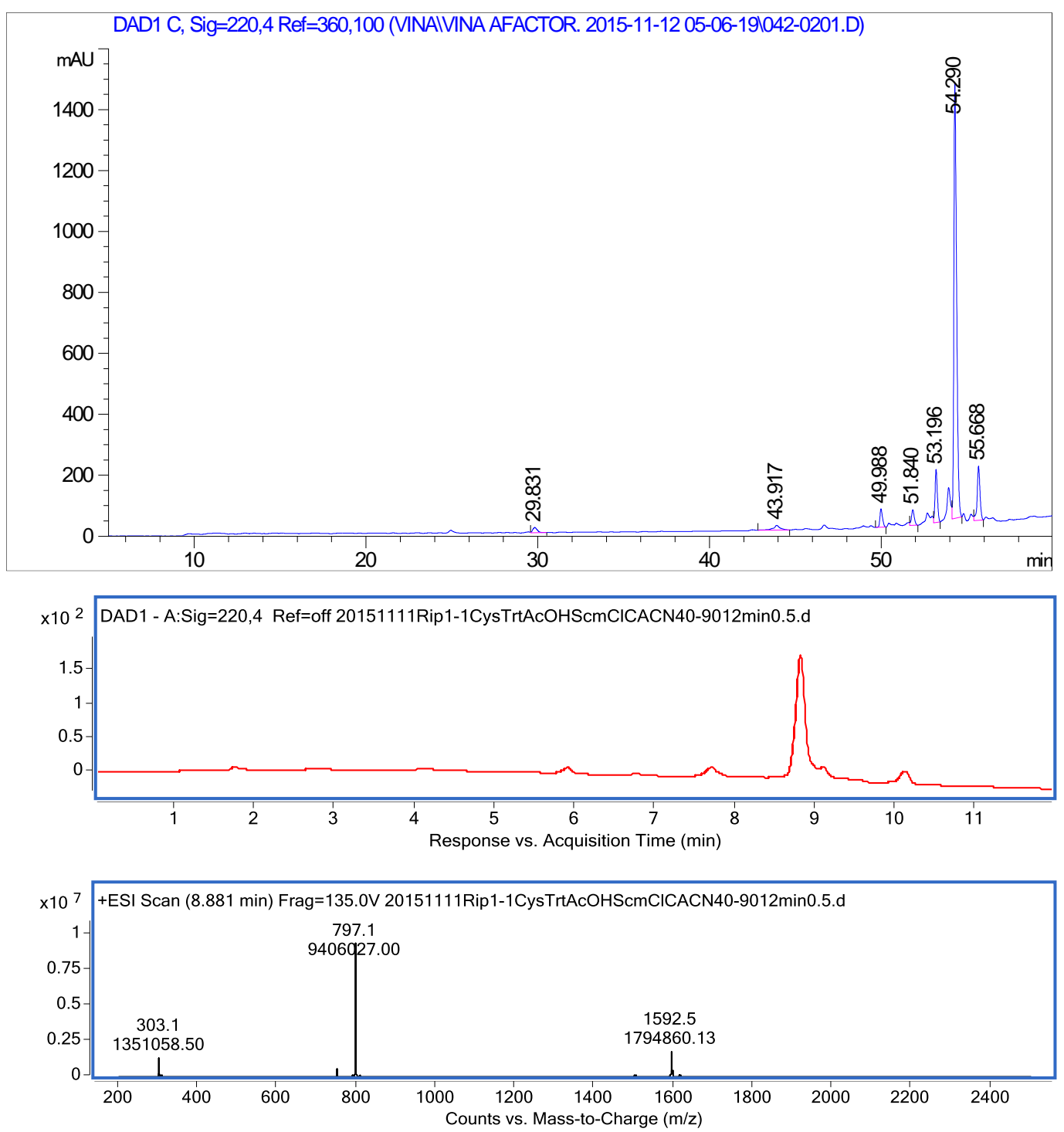

Figure S13: Crude HPLC and LCMS chromatograms for cleavage of 14a with 4 equiv of ScmCl in AcOH. LCMS trace retention times based on linear gradient from $40 \%$ to $90 \%$ ACN over $12 \mathrm{~min}$ 
Synthesis of side chain protected di-sulfenyl Riparin 1.1 (15) via 14b:
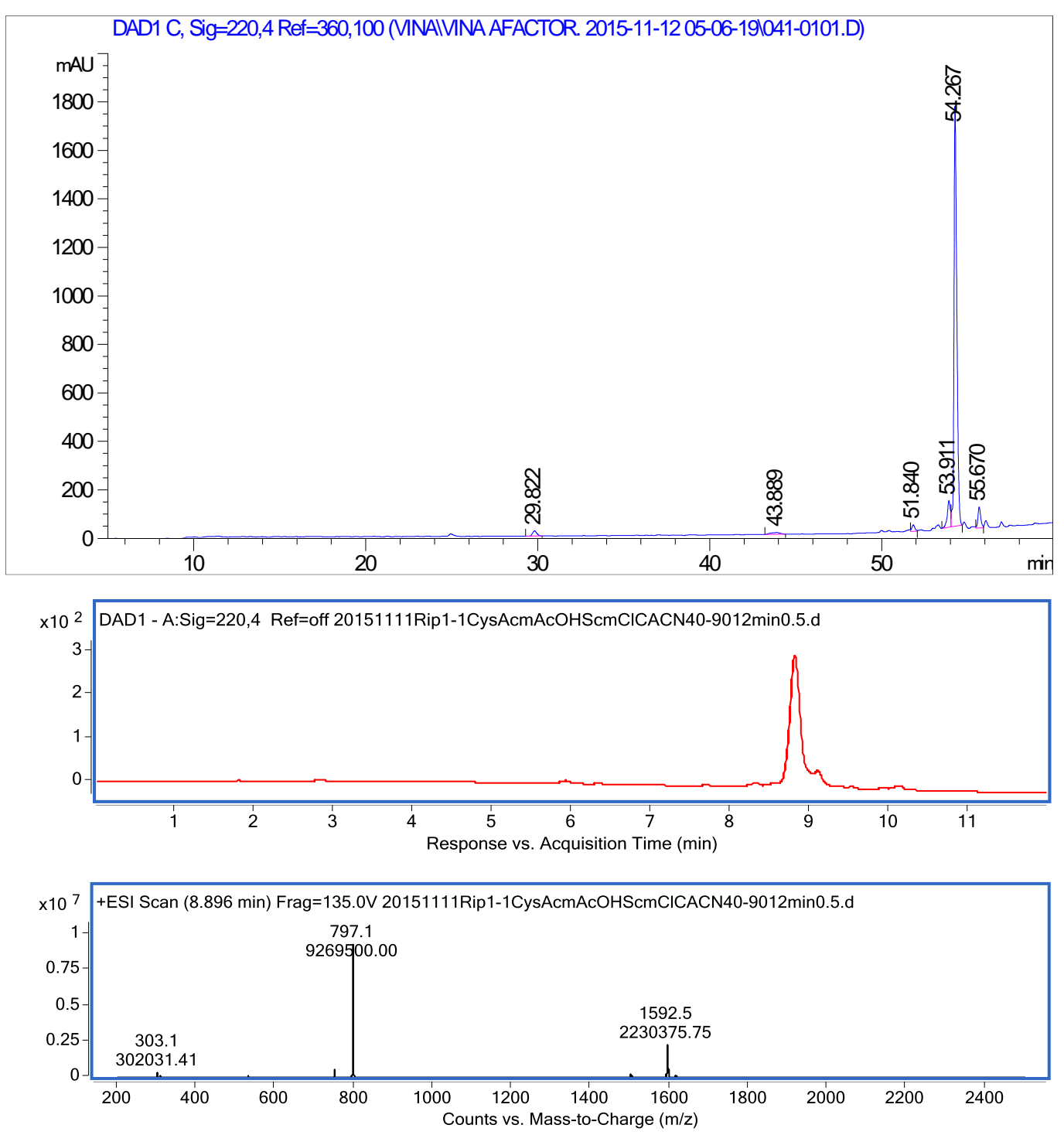

Figure S14: Crude HPLC and LCMS chromatograms for cleavage of $\mathbf{1 4 b}$ with 4 equiv of ScmCl in AcOH. LCMS trace retention times based on linear gradient from $40 \%$ to $90 \%$ ACN over 12 min 
Synthesis of side chain de-protected di-sulfenyl Riparin 1.1 (16) using method (b) via 14a:
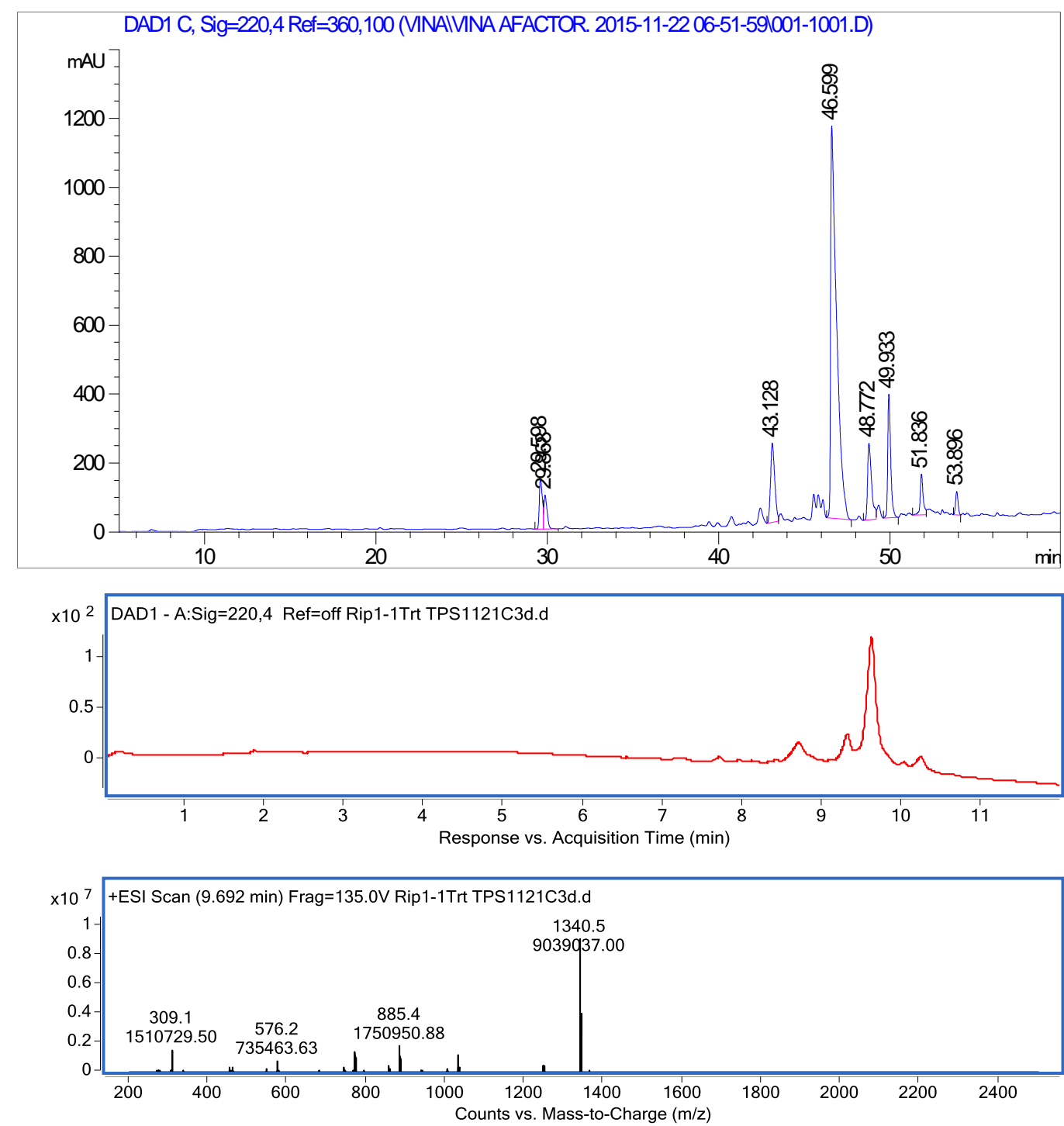

Figure S15: Crude HPLC and LCMS chromatograms for cleavage of 14a with 4 equiv of ScmCl in TFA:ScmCl:PhOH (94.75:0.25:5). LCMS trace retention times based on linear gradient from $20 \%$ to $90 \%$ ACN over 12 min 
Synthesis of side chain de-protected di-sulfenyl Riparin 1.1 (16) using method (b) via 14b:
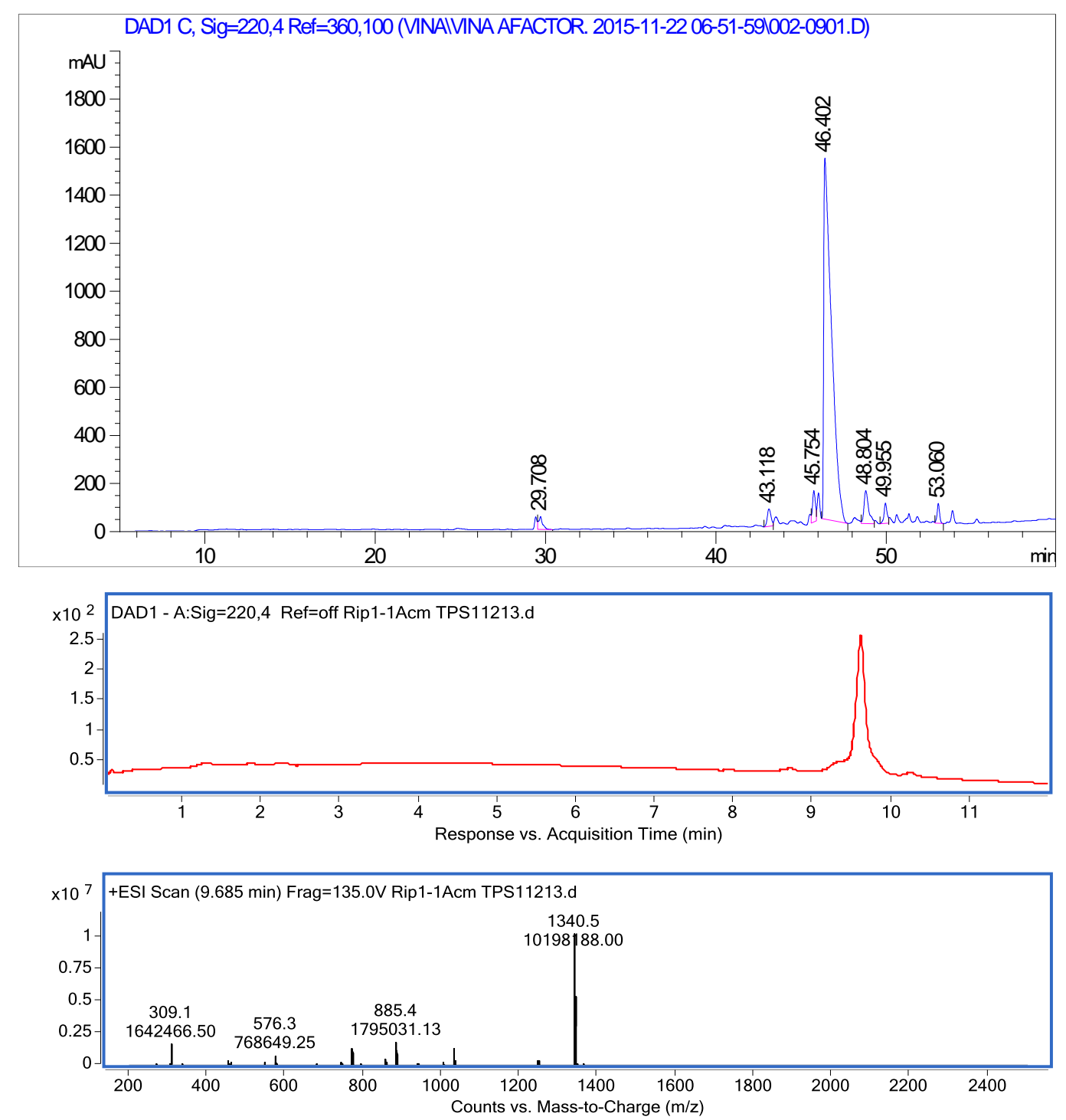

Figure S16: Crude HPLC and LCMS chromatograms for cleavage of 14b with 4 equiv ScmCl in TFA:ScmCl:PhOH (94.75:0.25:5) . LCMS trace retention times based on linear gradient from $20 \%$ to $90 \%$ ACN over 12 min 
Synthesis of side chain de-protected di-sulfenyl Riparin 1.1 (16) using method (c) via 14a:
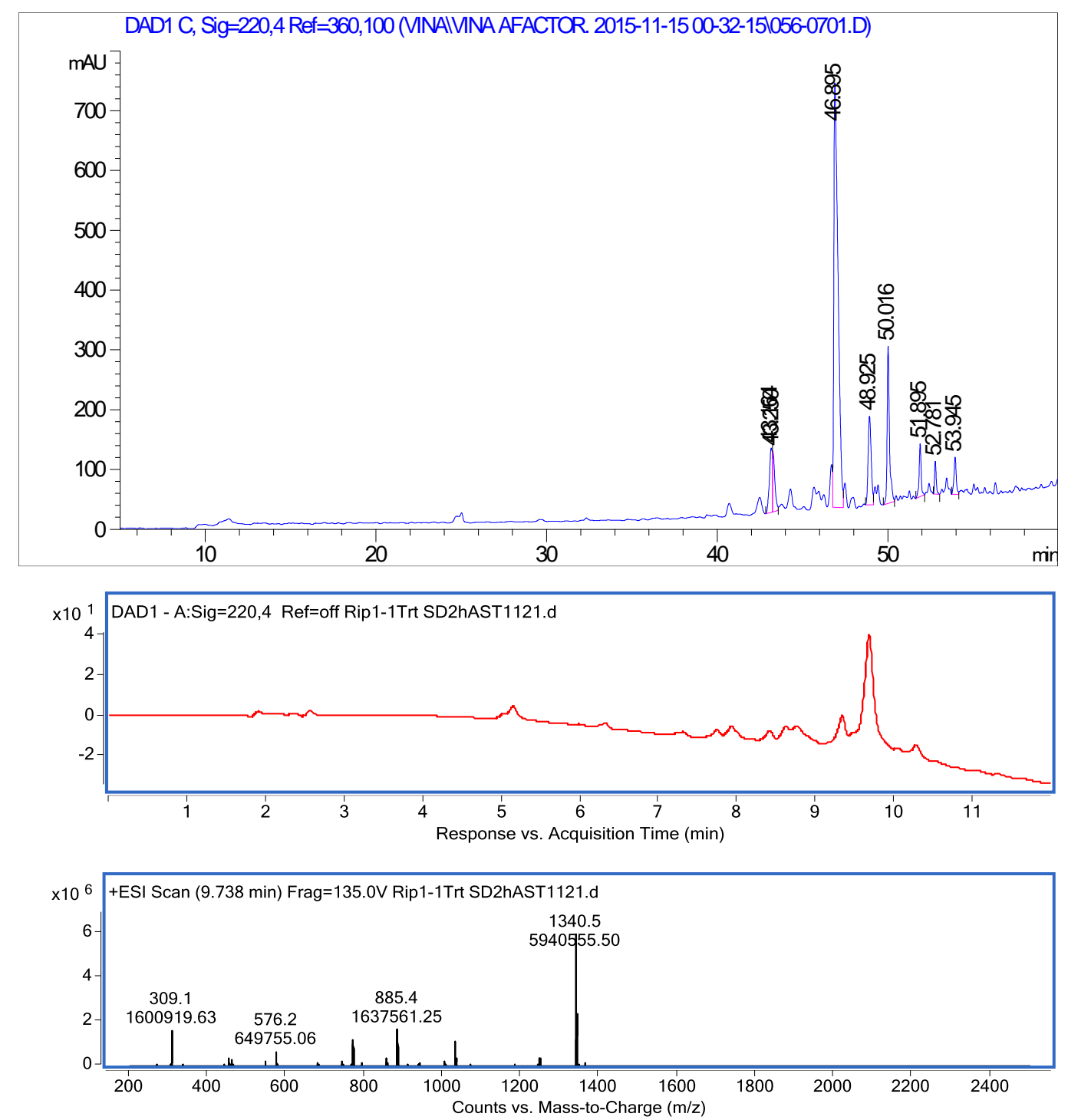

Figure S17: Crude HPLC and LCMS chromatograms for cleavage of 14a with a) TFA:TIPS: $\mathrm{H}_{2} \mathrm{O}: \mathrm{PhOH}(88: 2: 5: 5)$ for $2 \mathrm{~h}, \mathrm{~b}) 4$ equiv of $\mathrm{ScmCl}$ in $\mathrm{AcOH}$. LCMS trace retention times based on linear gradient from $20 \%$ to $90 \%$ ACN over $12 \mathrm{~min}$ 
Synthesis of side chain de-protected di-sulfenyl Riparin 1.1 (16) using method (c) via 14b:
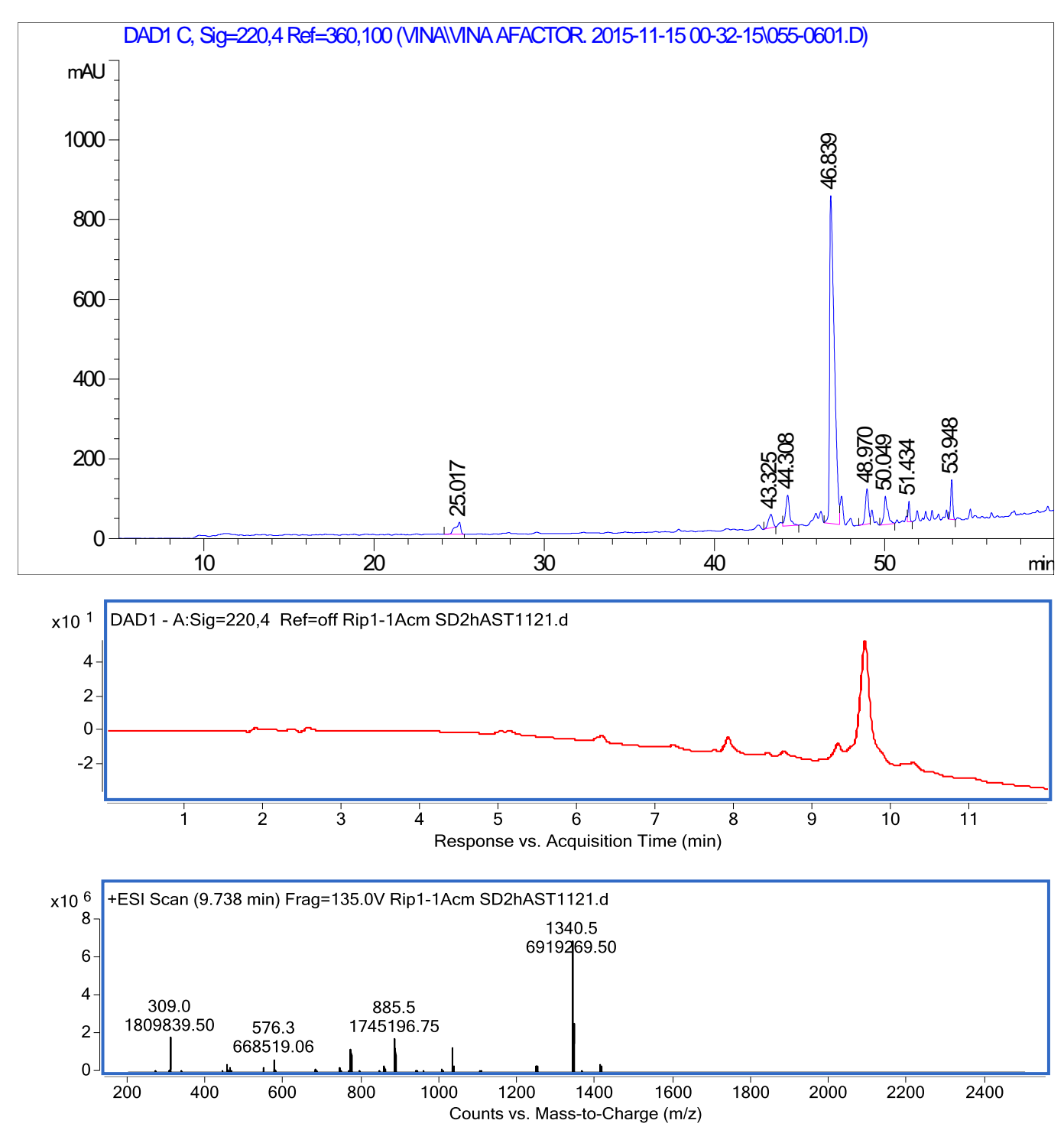

Figure S18: Crude HPLC and LCMS chromatograms for cleavage of 14b with a) TFA:TIPS: $\mathrm{H}_{2} \mathrm{O}: \mathrm{PhOH}(88: 2: 5: 5)$ for $2 \mathrm{~h}, \mathrm{~b}) 4$ equiv of $\mathrm{ScmCl}$ in $\mathrm{AcOH}$. LCMS trace retention times based on linear gradient from $20 \%$ to $90 \%$ ACN over $12 \mathrm{~min}$ 


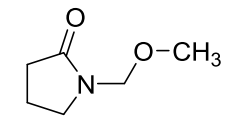

$2 a$
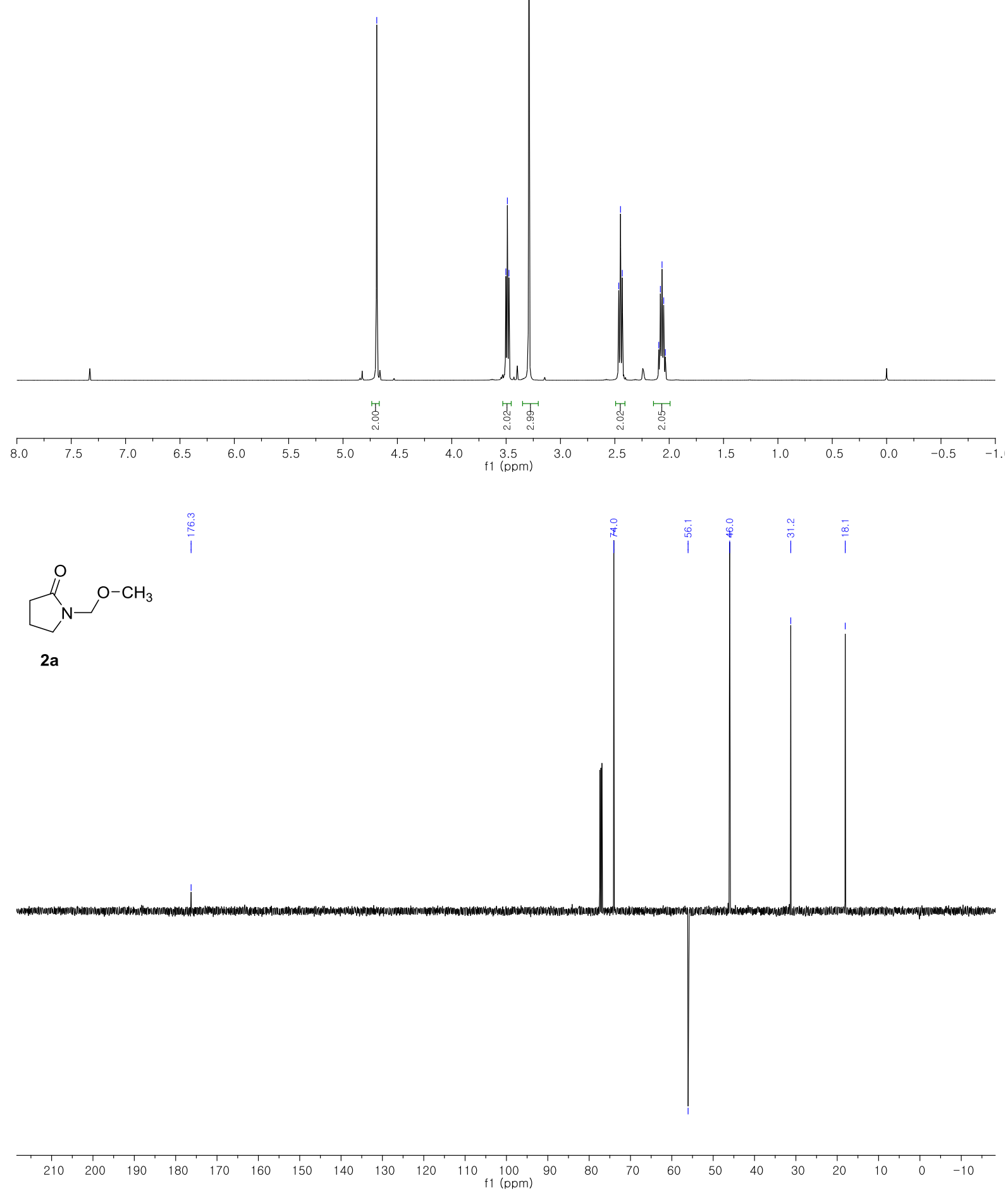

S 29 
i̊n

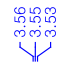

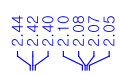

i
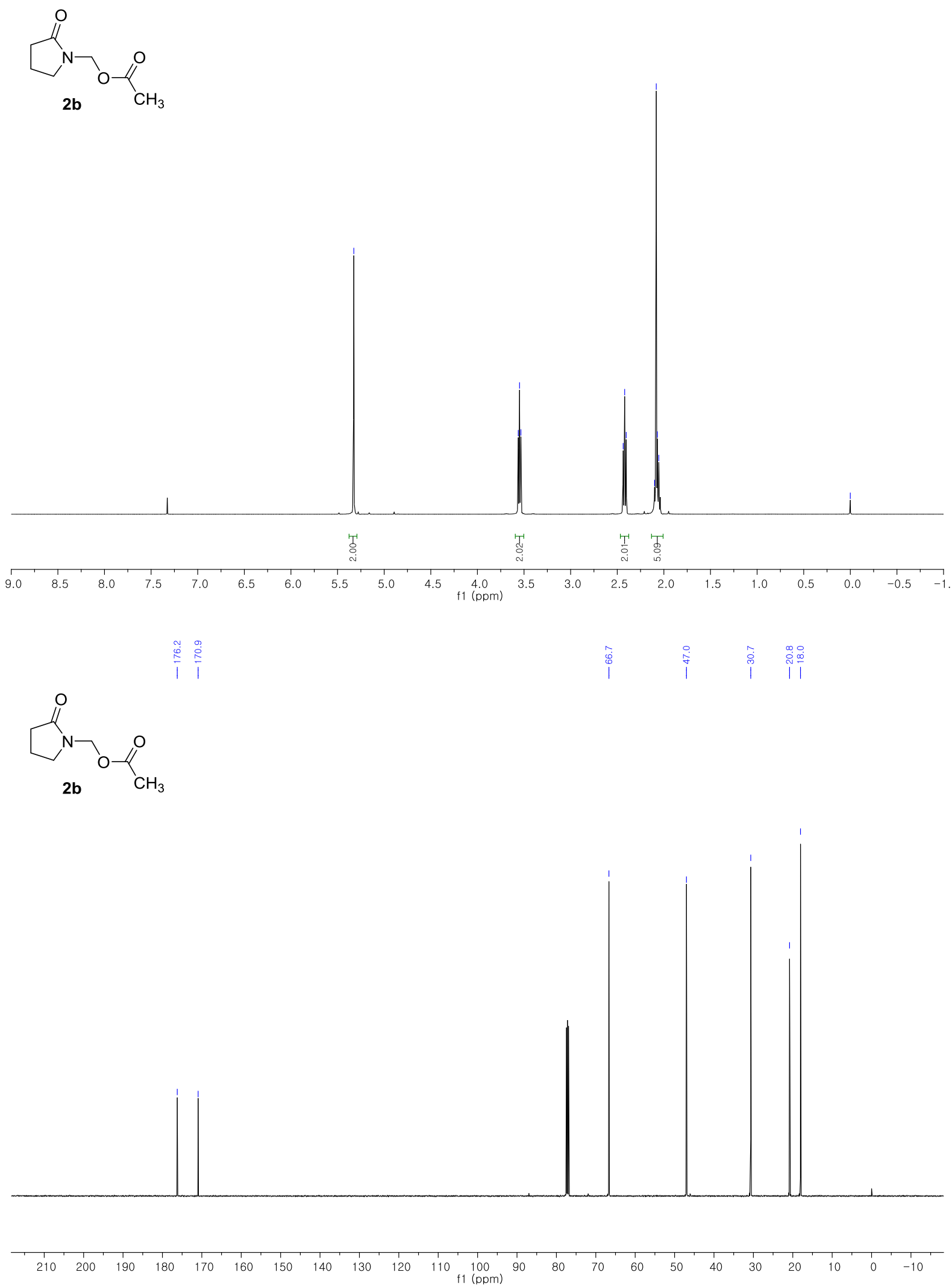

S 30 


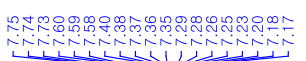

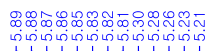

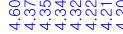

vis
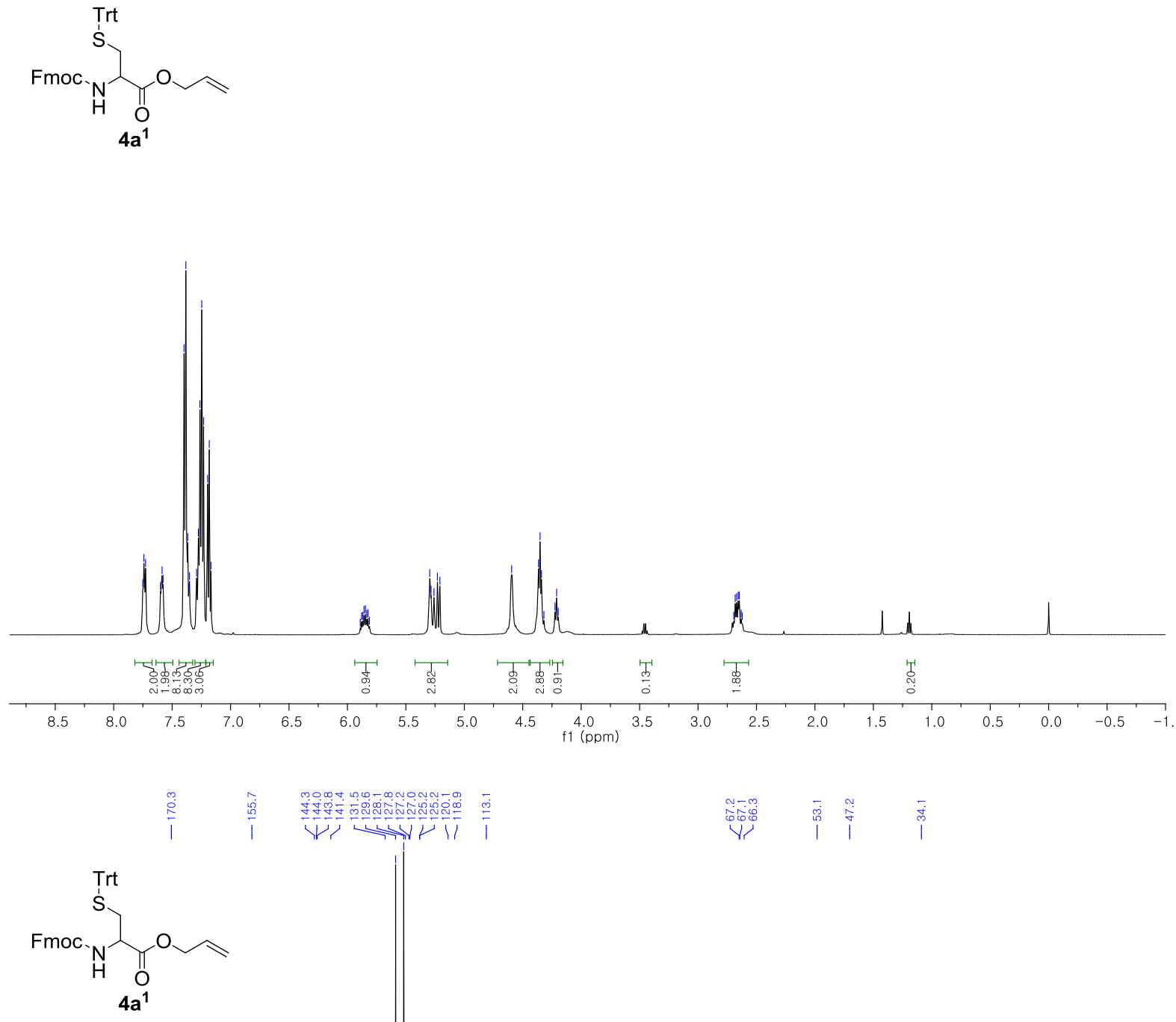

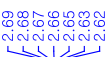

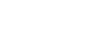




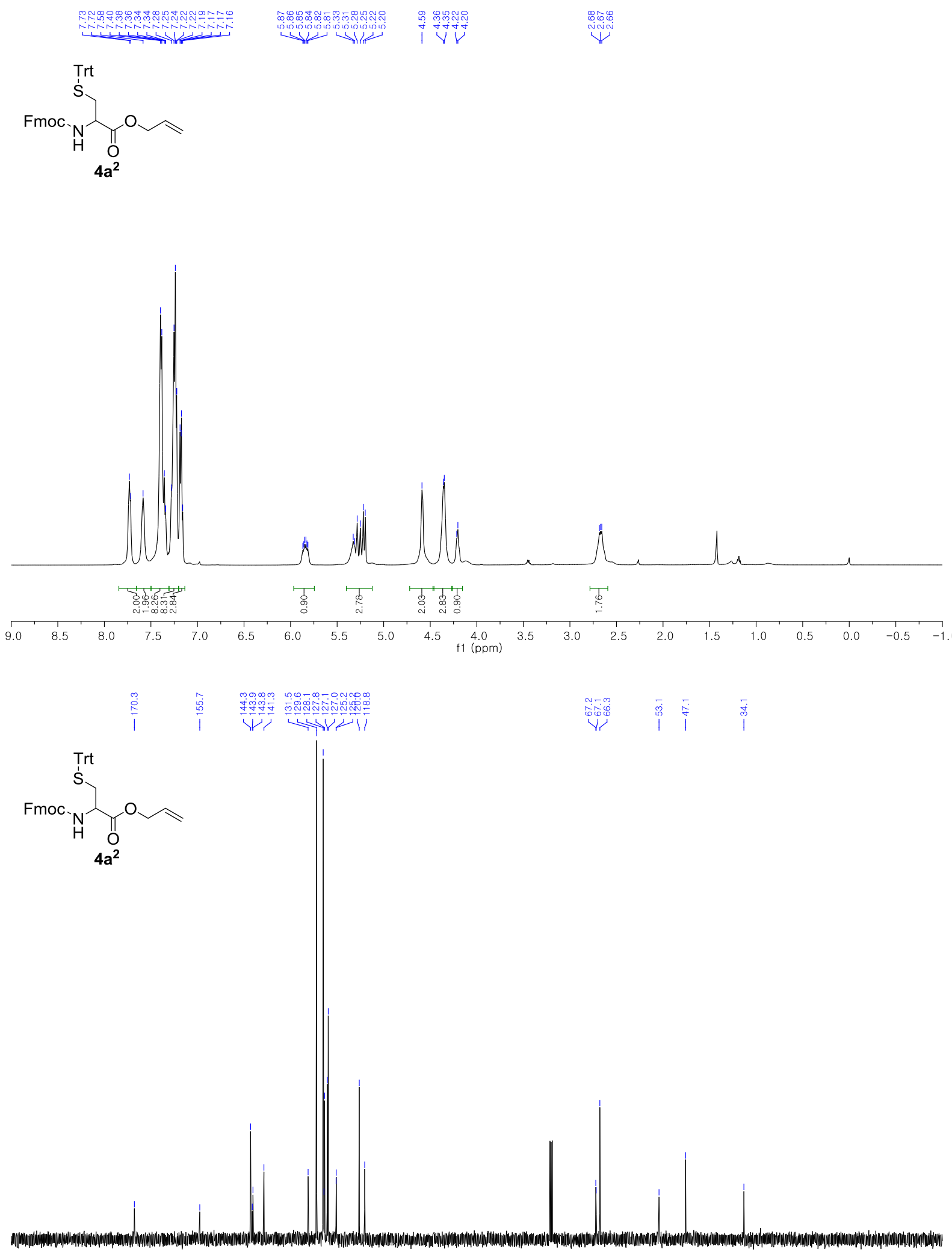

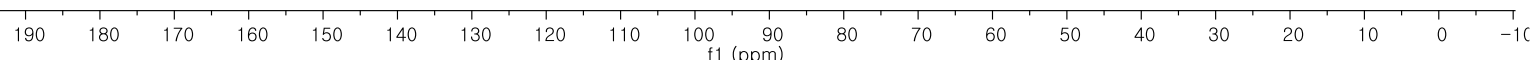



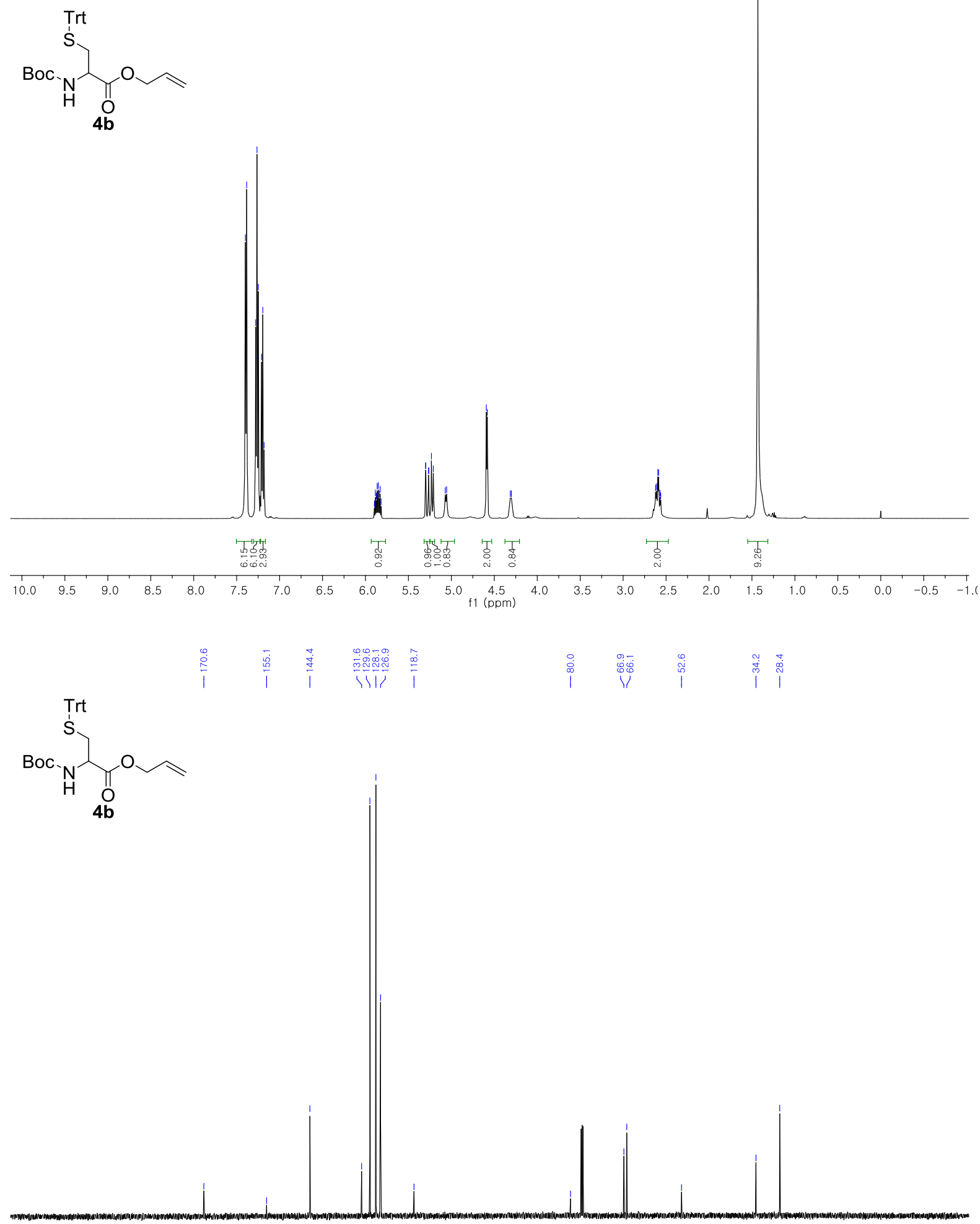

$\begin{array}{lllllllllllllllllllllllllllllllllllll}210 & 200 & 190 & 180 & 170 & 160 & 150 & 140 & 130 & 120 & 110 & 100 & 90 & 80 & 70 & 60 & 50 & 40 & 30 & 20 & 10 & 0 & -10\end{array}$ 


\section{LC MS/MS data of H-Gly-Phe-L-Cys(Scm)-OH $\left(8 \mathbf{a}^{1}\right)$}
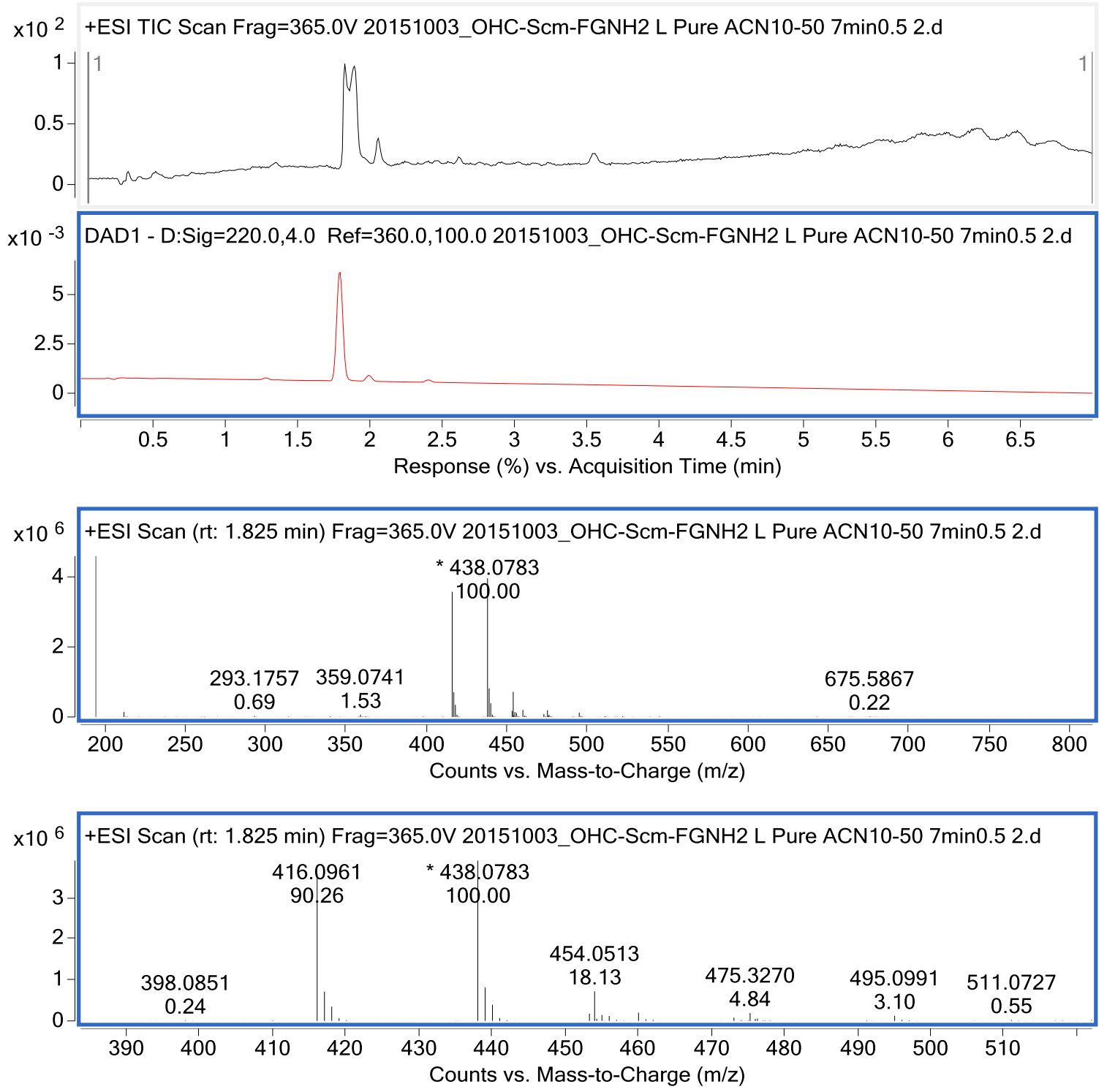

Figure S19: Pure LCMS/MS chromatogram of $\mathbf{8 a}^{\mathbf{1}}$ in ESI mode. Top trace: Total ion count from ESI MS/MS. Bottom trace: $\mathrm{UV}$ at $220 \mathrm{~nm}$ (linear gradient from $10 \%$ to $50 \% \mathrm{ACN}$ over $7 \mathrm{~min}, \mathrm{t}_{\mathrm{R}}: 1.8 \mathrm{~min}$ ) 


\section{LC MS/MS data of H-Gly-Phe-D-Cys(Scm)-OH $\left(\mathbf{8 a}^{2}\right)$}
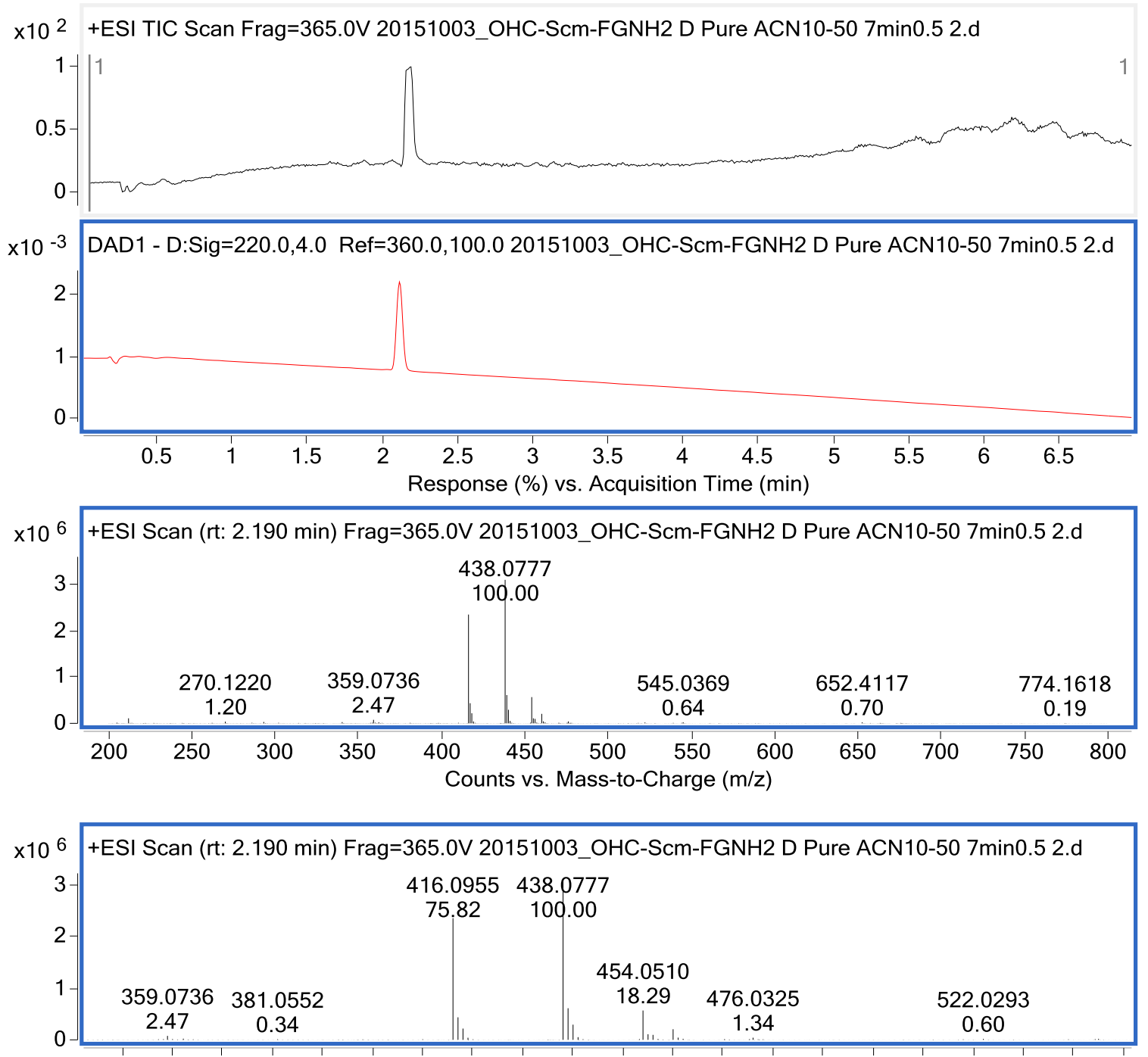

$350360 \quad 370380 \quad 390 \quad 400 \quad 410420 \quad 430 \quad 440 \quad 450 \quad 460 \quad 470 \quad 480490500510 \quad 520530540$ Counts vs. Mass-to-Charge $(\mathrm{m} / \mathrm{z})$

Figure S20: Pure LCMS/MS chromatogram of $\mathbf{8 a}^{\mathbf{2}}$ in ESI mode. Top trace: Total ion count from ESI MS/MS. Bottom trace: $\mathrm{UV}$ at $220 \mathrm{~nm}$ (linear gradient from $10 \%$ to $50 \% \mathrm{ACN}$ over $7 \mathrm{~min}, \mathrm{t}_{\mathrm{R}}: 2.2 \mathrm{~min}$ ) 


\section{LC MS/MS data of co-injected H-Gly-Phe-L-Cys(Scm)-OH and H-Gly-Phe-D-Cys(Scm)-OH}

x10 2 +ESI TIC Scan Frag=365.0V 20151003_OHC-Scm-FGNH2 L\&D Coinject Pure ACN10-50 7min0.5 2.d
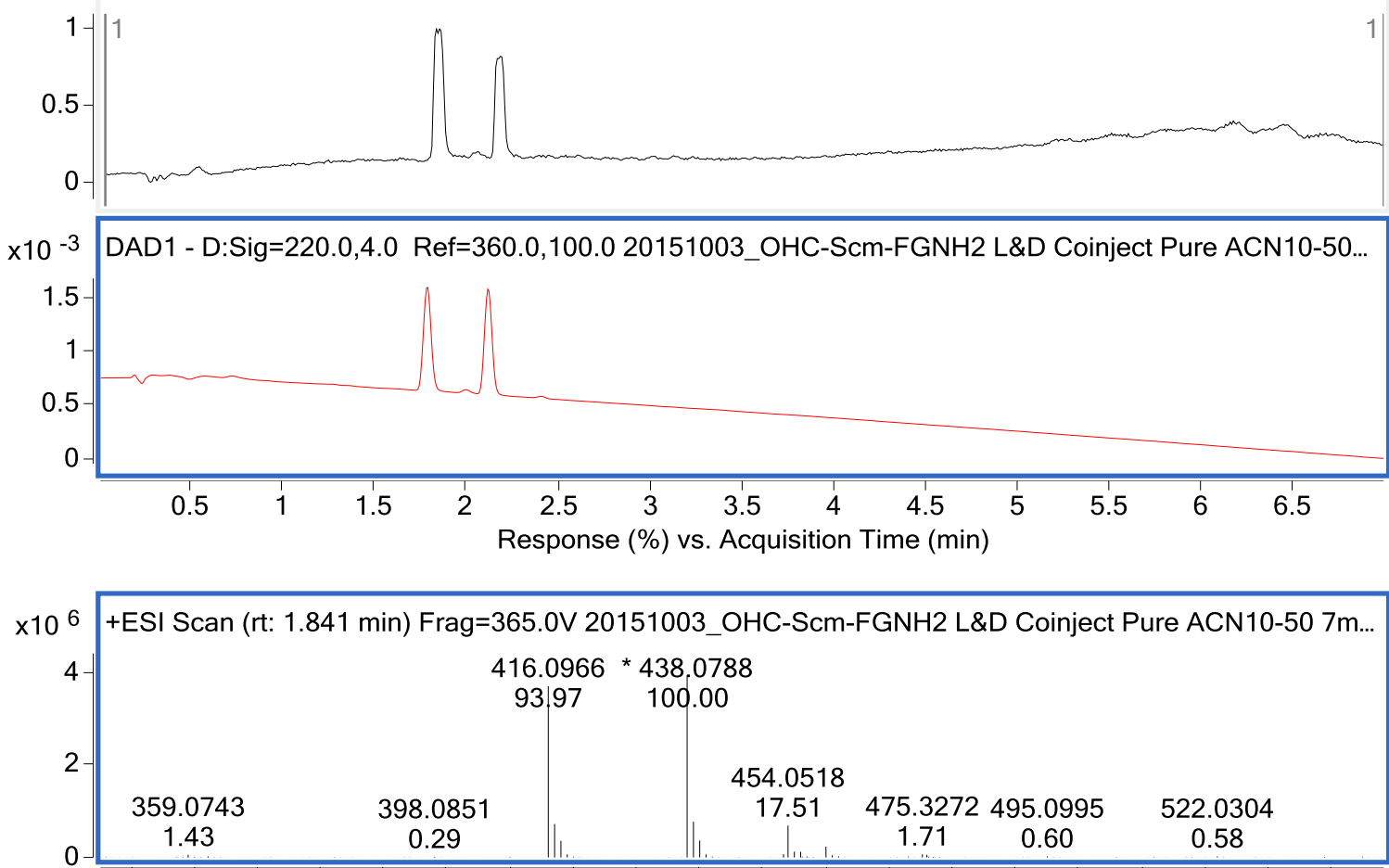

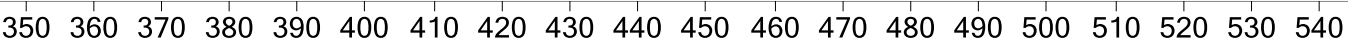
Counts vs. Mass-to-Charge $(\mathrm{m} / \mathrm{z})$

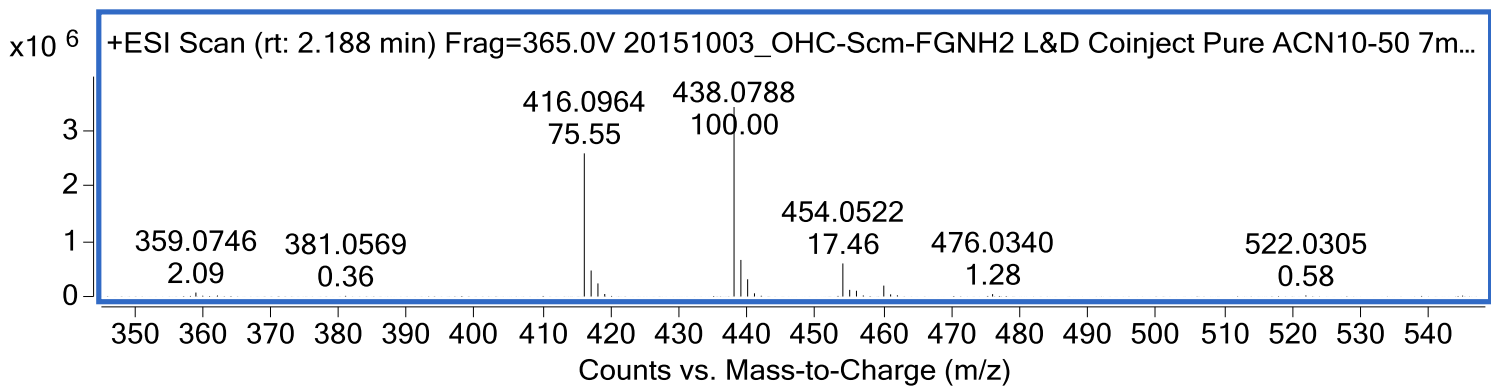

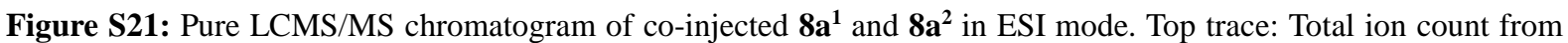
ESI MS/MS. Bottom trace: UV at $220 \mathrm{~nm}$ (linear gradient from $10 \%$ to $50 \% \mathrm{ACN}$ over $7 \mathrm{~min}, \mathrm{t}_{\mathrm{R}}: 1.8 \mathrm{~min}$ and $2.2 \mathrm{~min}$ respectively) 
LC MS/MS data of side chain protected di-sulfenyl Riparin 1.2 (10):
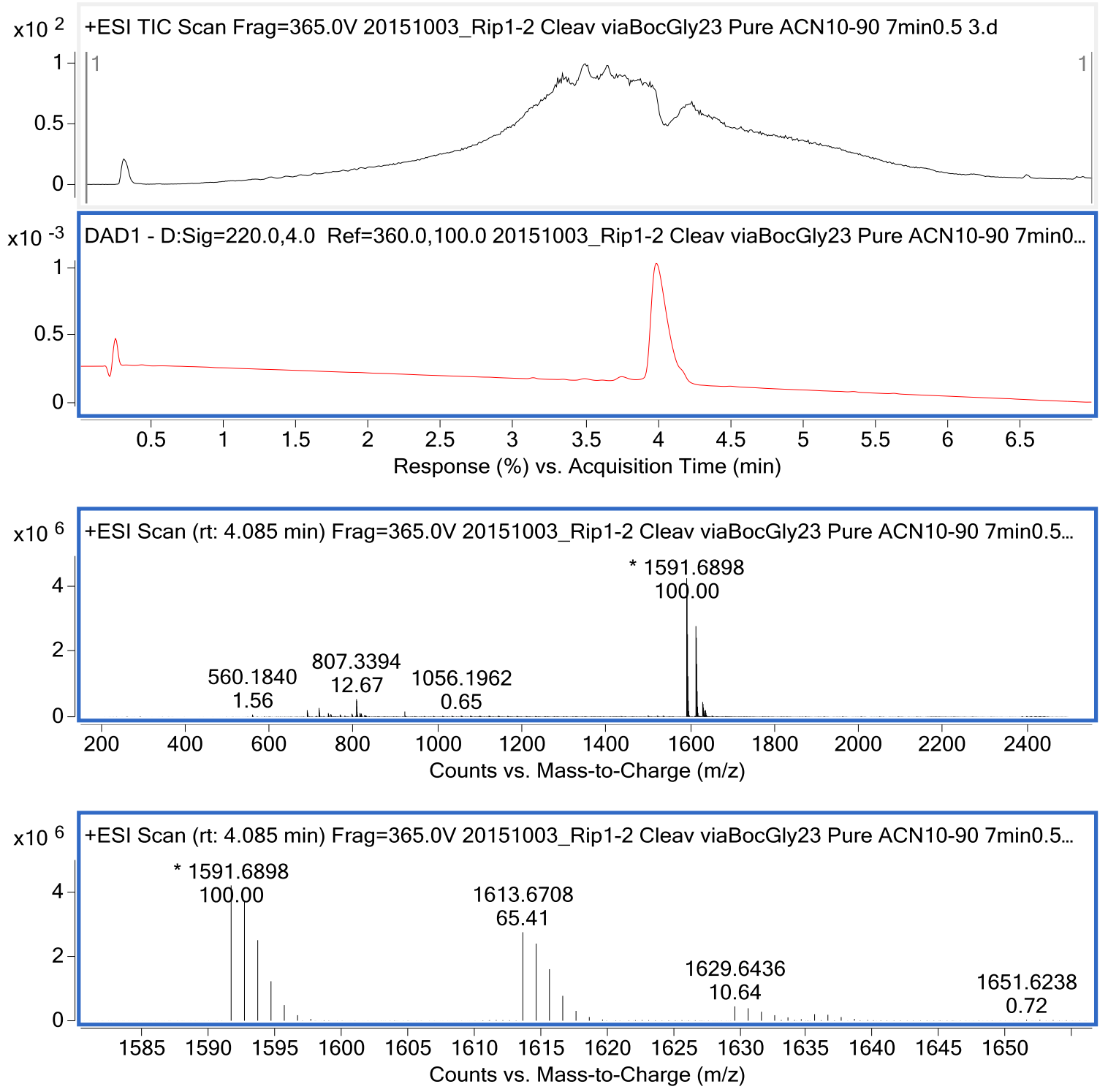

Figure S22: Pure LCMS/MS chromatogram of $\mathbf{1 0}$ in ESI mode. Top trace: Total ion count from ESI MS/MS. Bottom trace: $\mathrm{UV}$ at $220 \mathrm{~nm}$ (linear gradient from $10 \%$ to $90 \% \mathrm{ACN}$ over $7 \mathrm{~min}, \mathrm{t}_{\mathrm{R}}: 4.1 \mathrm{~min}$ ) 
LC MS/MS data of side chain deprotected di-sulfenyl Riparin 1.2 (11):
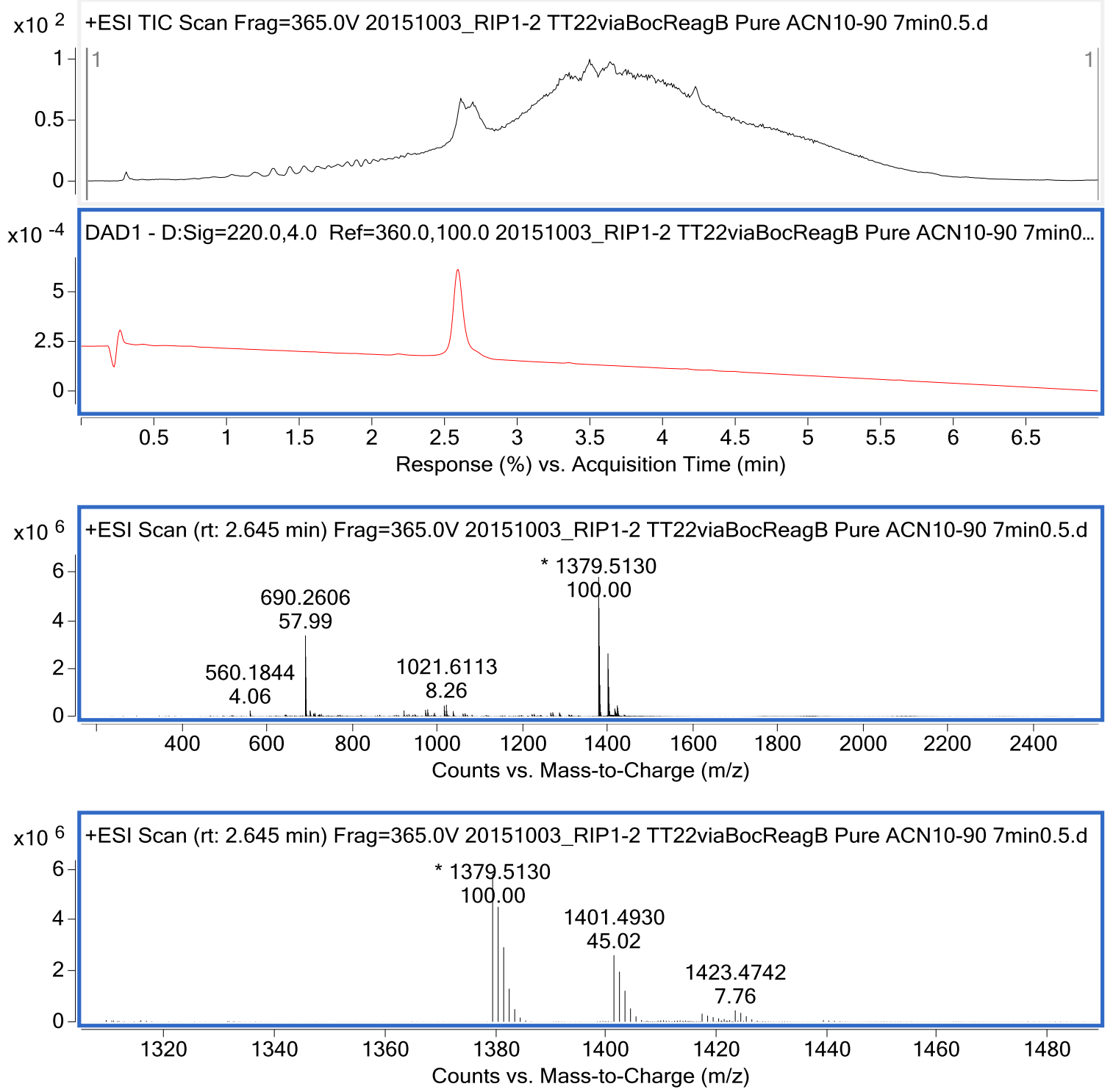

Figure S23: Pure LCMS/MS chromatogram of $\mathbf{1 1}$ in ESI mode. Top trace: Total ion count from ESI MS/MS. Bottom trace: $\mathrm{UV}$ at $220 \mathrm{~nm}$ (linear gradient from $10 \%$ to $90 \% \mathrm{ACN}$ over $7 \mathrm{~min}, \mathrm{t}_{\mathrm{R}}: 2.6 \mathrm{~min}$ ) 
LC MS/MS data of reduced Riparin $1.2(12)$ :
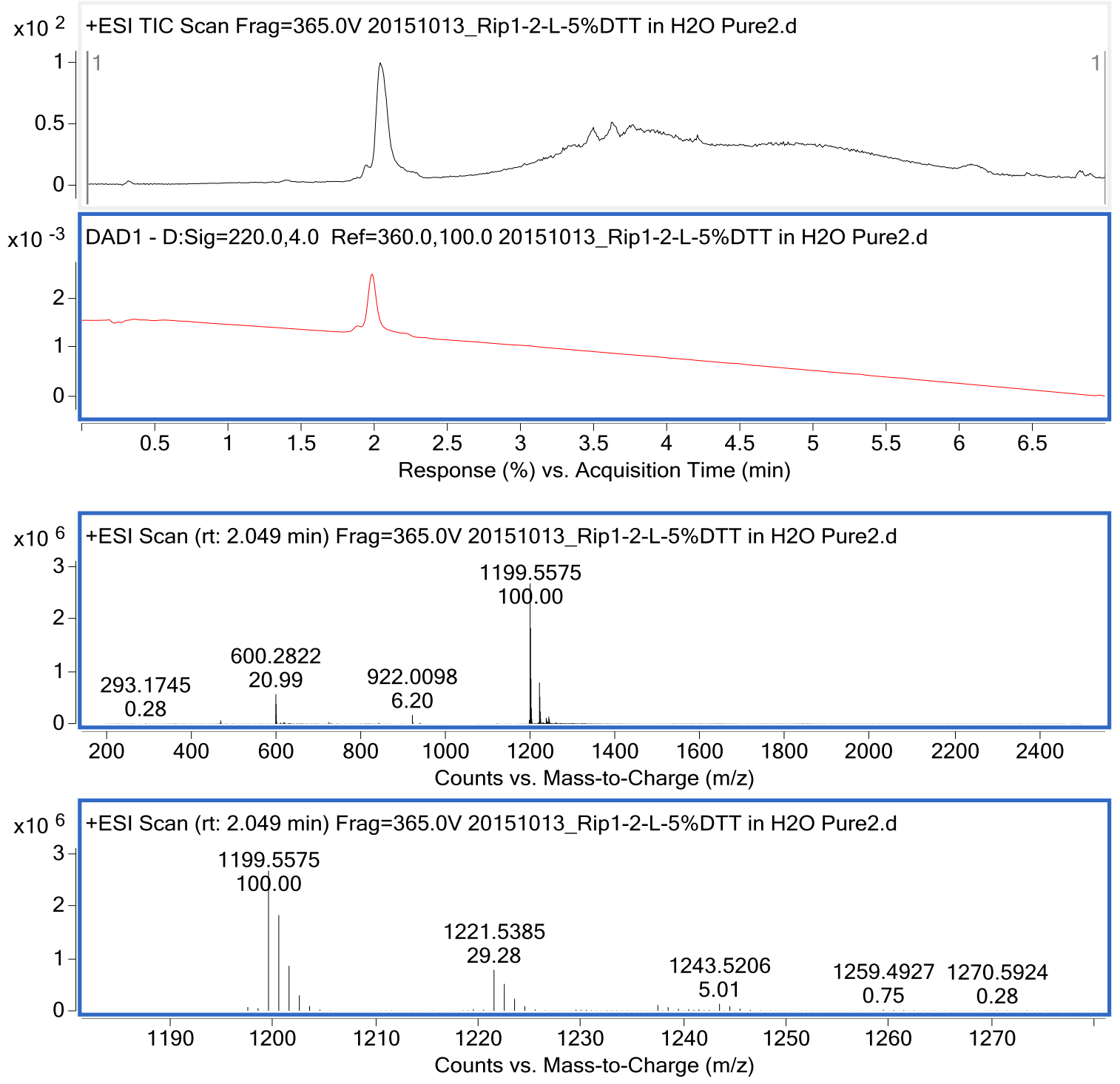

Figure S24: Pure LCMS/MS chromatogram of 12 in ESI mode. Top trace: Total ion count from ESI MS/MS. Bottom trace: UV at $220 \mathrm{~nm}$ (linear gradient from $10 \%$ to $90 \% \mathrm{ACN}$ over $7 \mathrm{~min}, \mathrm{t}_{\mathrm{R}}: 2.1 \mathrm{~min}$ ) 
LC MS/MS data of Riparin $1.2(13)$ :
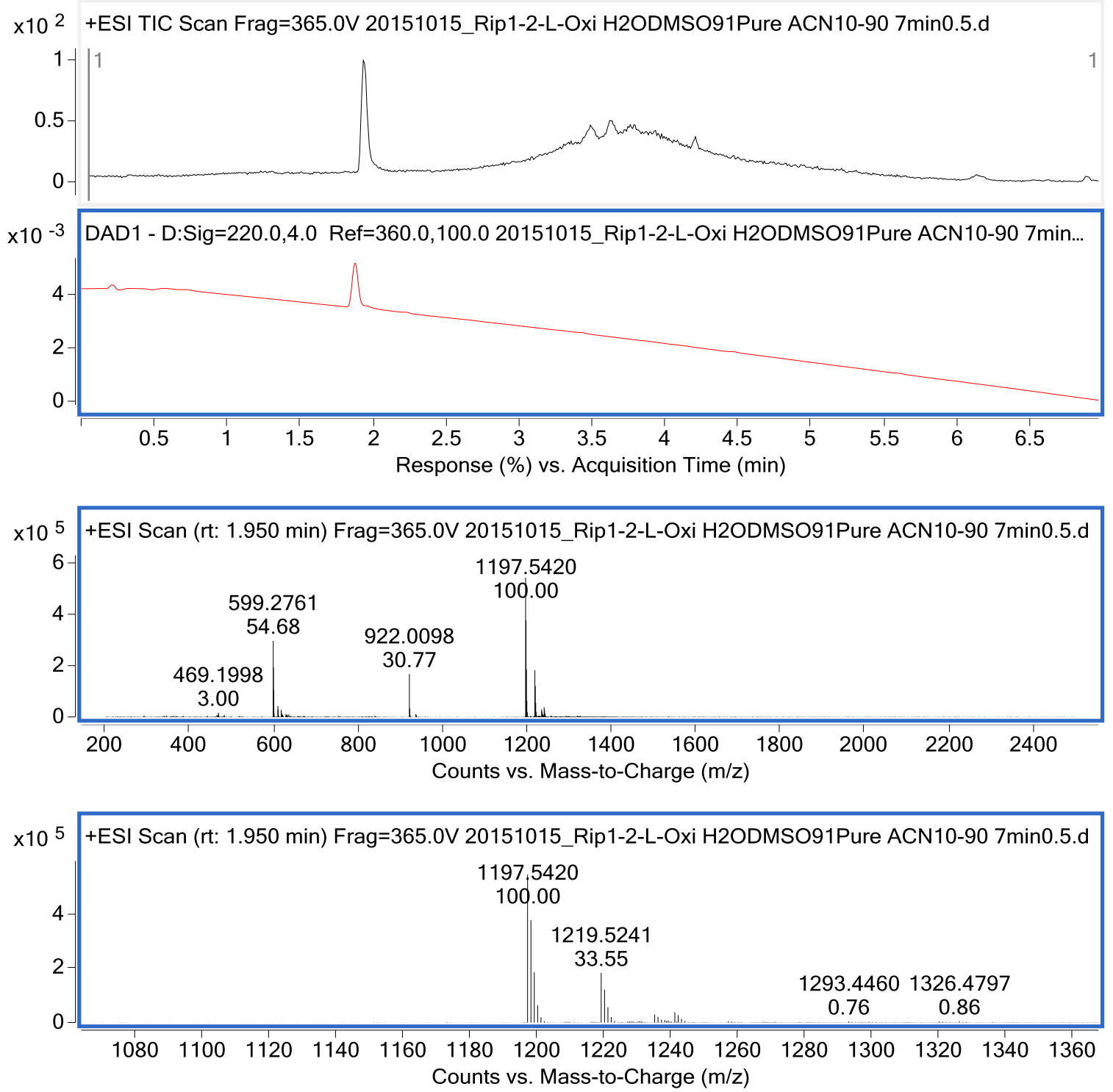

Figure S25: Pure LCMS/MS chromatogram of $\mathbf{1 3}$ in ESI mode. Top trace: Total ion count from ESI MS/MS. Bottom trace: $\mathrm{UV}$ at $220 \mathrm{~nm}$ (linear gradient from $10 \%$ to $90 \%$ ACN over $7 \mathrm{~min}, \mathrm{t}_{\mathrm{R}}: 2 \mathrm{~min}$ ) 
LC MS/MS data of side chain protected di-sulfenyl Riparin 1.1 (15):
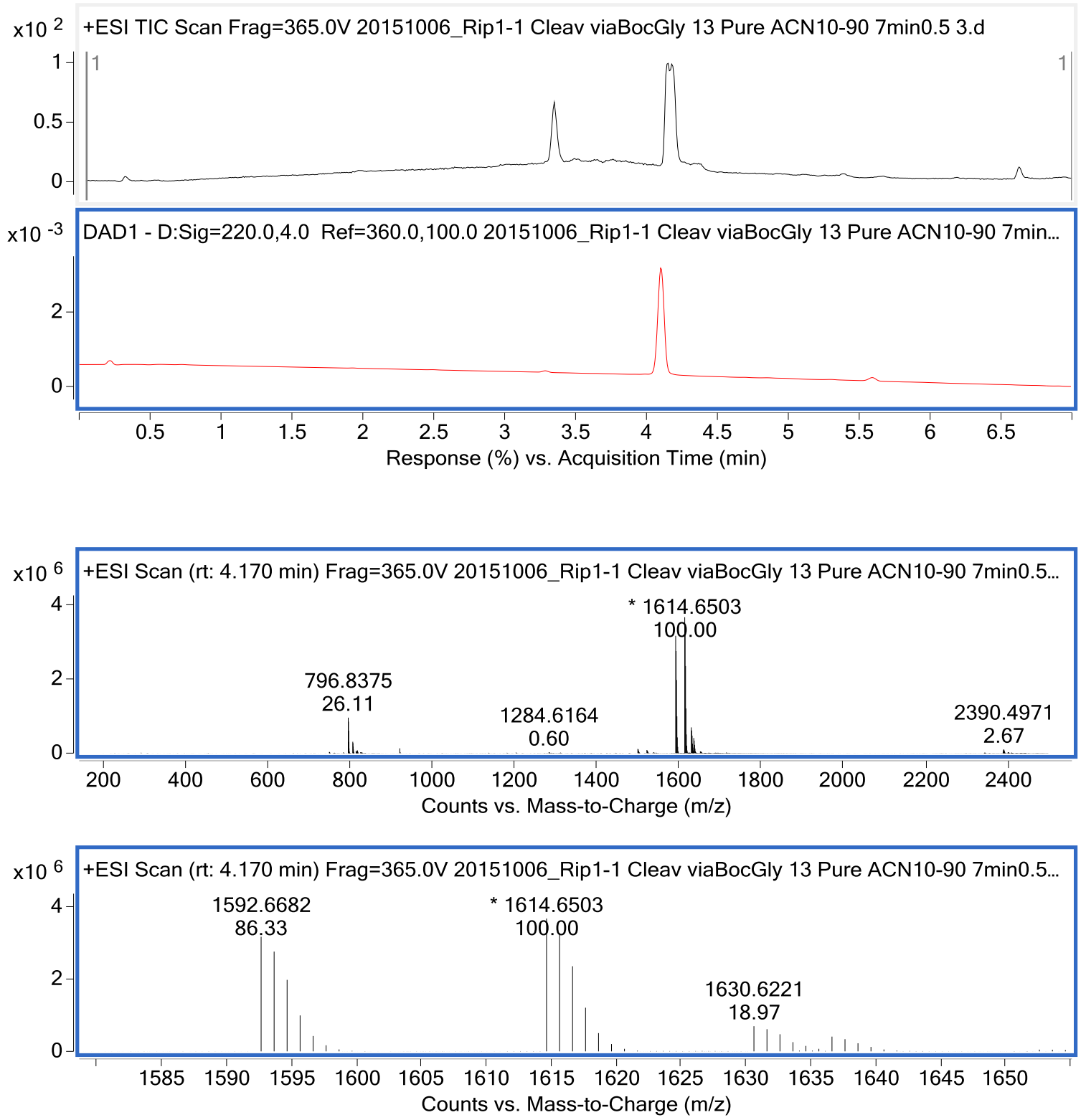

Figure S26: Pure LCMS/MS chromatogram of $\mathbf{1 5}$ in ESI mode. Top trace: Total ion count from ESI MS/MS. Bottom trace: UV at $220 \mathrm{~nm}$ (linear gradient from $10 \%$ to $90 \% \mathrm{ACN}$ over $7 \mathrm{~min}, \mathrm{t}_{\mathrm{R}}: 4.2 \mathrm{~min}$ ) 
LC MS/MS data of side chain deprotected di-sulfenyl Riparin 1.1 (16):
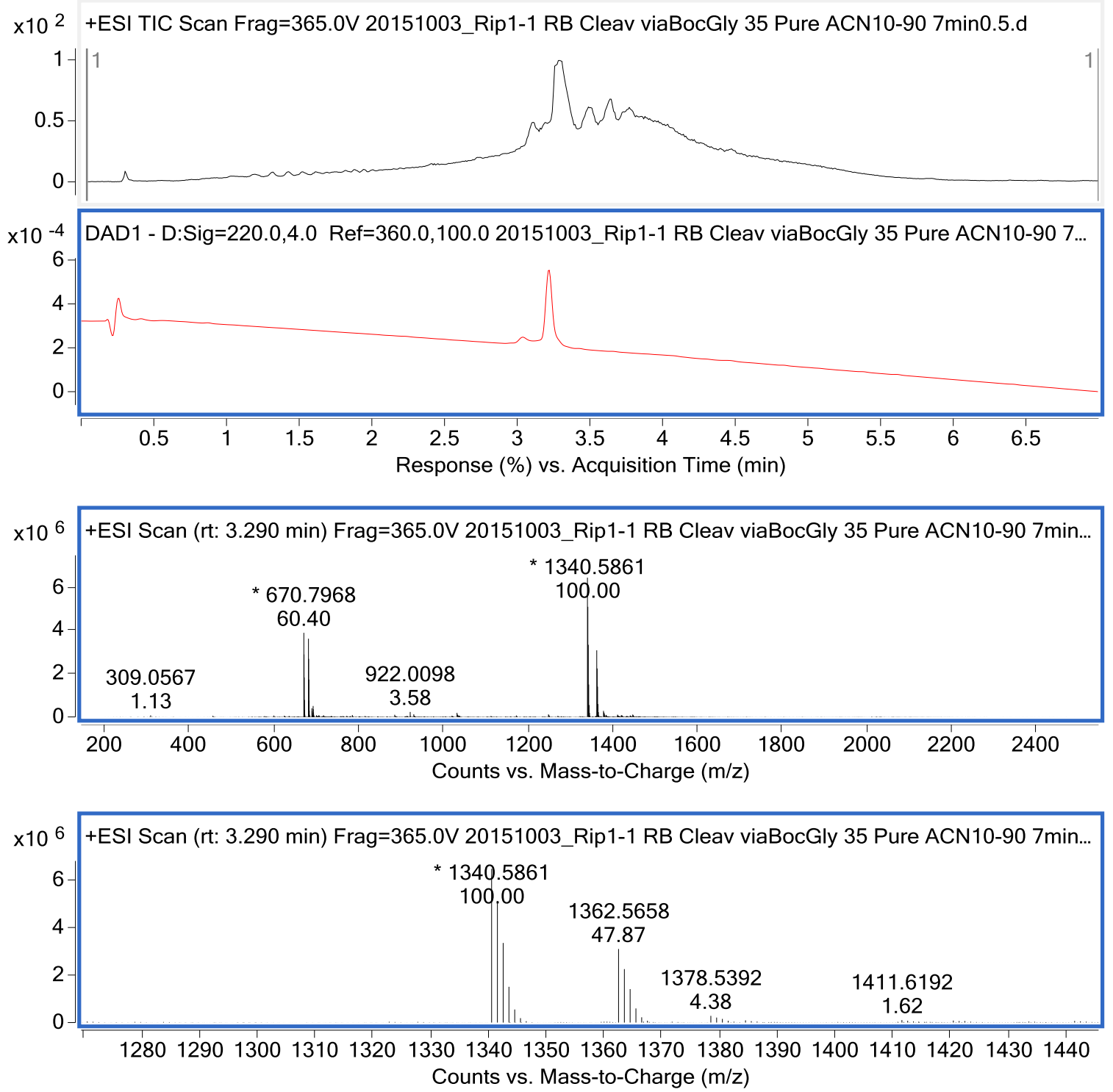

Figure S27: Pure LCMS/MS chromatogram of $\mathbf{1 6}$ in ESI mode. Top trace: Total ion count from ESI MS/MS. Bottom trace: $\mathrm{UV}$ at $220 \mathrm{~nm}$ (linear gradient from $10 \%$ to $90 \% \mathrm{ACN}$ over $7 \mathrm{~min}, \mathrm{t}_{\mathrm{R}}: 3.3 \mathrm{~min}$ ) 
LC MS/MS data of reduced Riparin $1.1(17)$ :
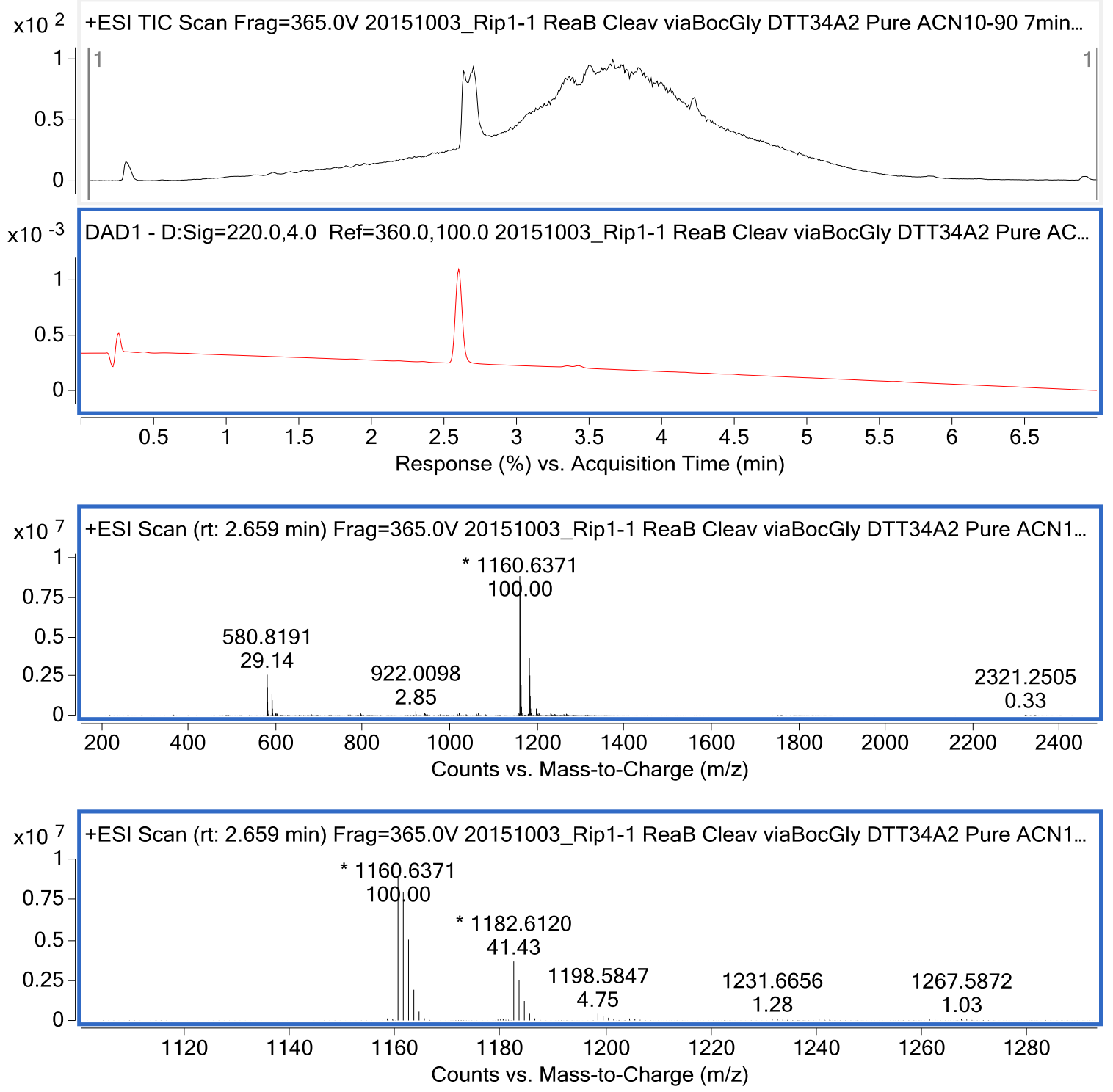

Figure S28: Pure LCMS/MS chromatogram of $\mathbf{1 7}$ in ESI mode. Top trace: Total ion count from ESI MS/MS. Bottom trace: $\mathrm{UV}$ at $220 \mathrm{~nm}$ (linear gradient from $10 \%$ to $90 \% \mathrm{ACN}$ over $7 \mathrm{~min}, \mathrm{t}_{\mathrm{R}}: 2.7 \mathrm{~min}$ ) 


\section{LCMS data of pure Riparin $1.1(18)$ :}
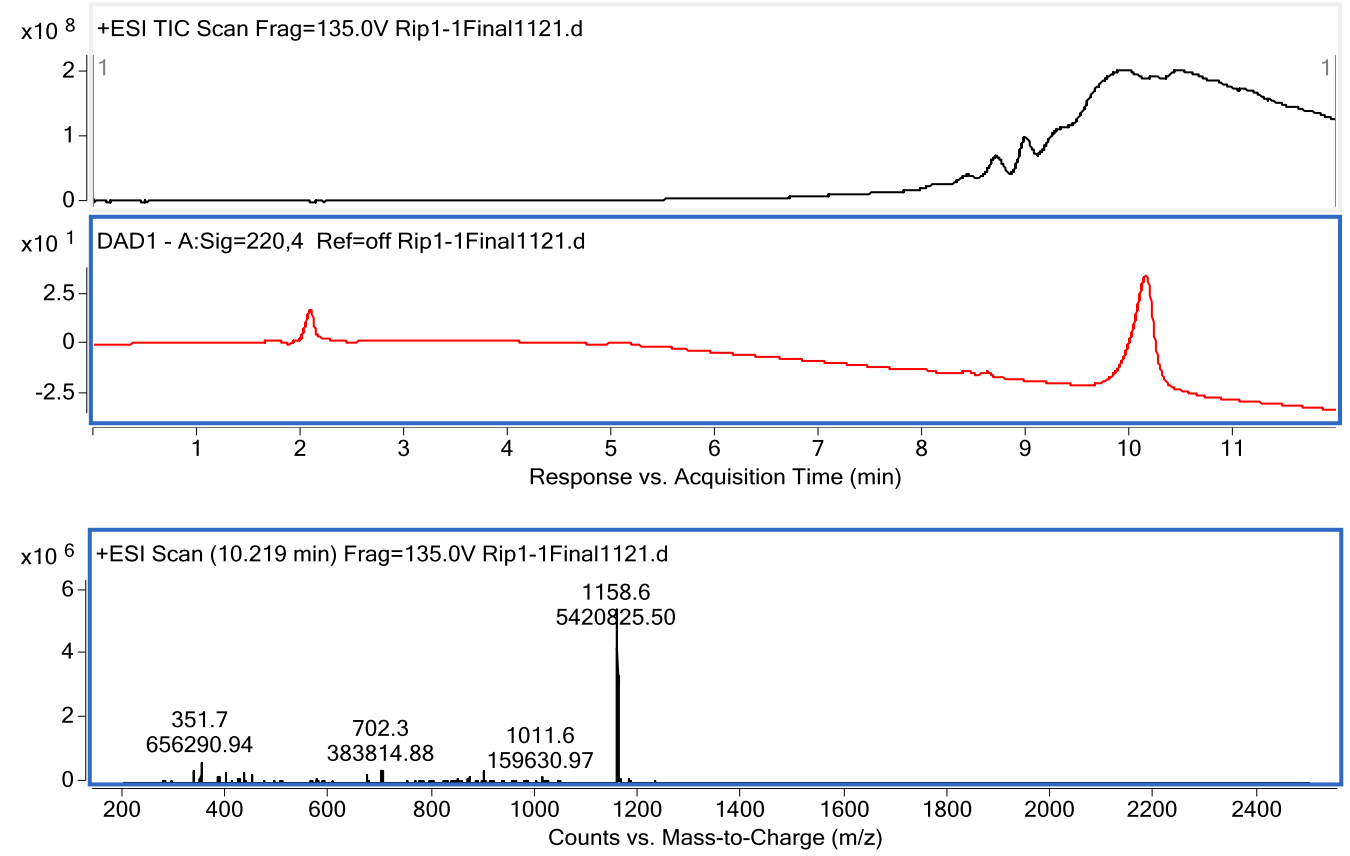

Figure S29: Pure LCMS chromatogram of 18 in ESI mode. Top trace: Total ion count from ESI MS. Bottom trace: UV at $220 \mathrm{~nm}$ (linear gradient from $10 \%$ to $90 \% \mathrm{ACN}$ over $12 \mathrm{~min}, \mathrm{t}_{\mathrm{R}}: 10.2 \mathrm{~min}$ )

\section{References:}

(1) Schnölzer, M.; Alewood, P.; Jones, A.; Alewood, D.; Kent, S. B. H. Int. J. Pept. Protein Res. 1992, 40, 180.

(2) Newcomb, W. S.; Deegan, T. L.; Miller, W.; Porco, J. A. Biotechnol. Bioeng. 1998, 61, 55.

(3) Sarin, V. K.; Kent, S. B. H.; Tam, J. P.; Merrifield, R. B. Anal. Biochem. 1981, 117, 147.

(4) Seyberth, T.; Voss, S.; Brock, R.; Wiesmüller, K.-H.; Jung, G. J. Med. Chem. 2006, 49, 1754. 